Prepared in cooperation with Clean Water Services

\title{
Modeling Water Quality Effects of Structural and Operational Changes to Scoggins Dam and Henry Hagg Lake, Oregon
}

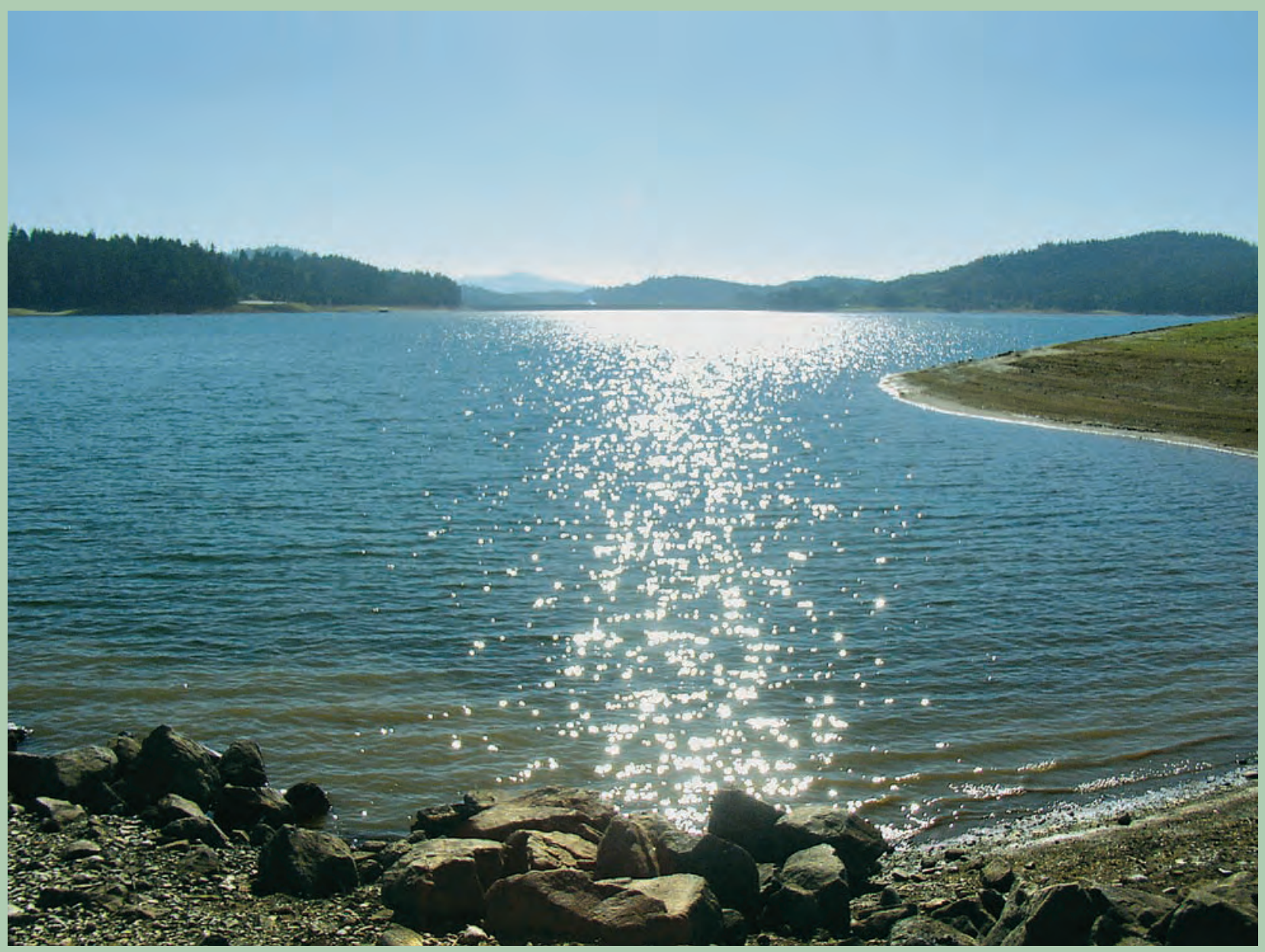

Scientific Investigations Report 2006-5060 
Front Cover: Photograph of Henry Hagg Lake looking toward Scoggins Dam from the boat ramp at picnic area C. (Photograph taken by Stewart Rounds, U.S. Geological Survey, September 22, 2004.)

Back cover: Photograph of the mouth of Sain Creek. (Photograph taken by Stewart Rounds, U.S. Geological Survey, September 22, 2004.) 


\section{Modeling Water Quality Effects of Structural and Operational Changes to Scoggins Dam and Henry Hagg Lake, Oregon}

By Annett B. Sullivan and Stewart A. Rounds

Prepared in cooperation with Clean Water Services

Scientific Investigations Report 2006-5060 


\section{U.S. Department of the Interior \\ Dirk Kempthorne, Secretary \\ U.S. Geological Survey \\ P. Patrick Leahy, Acting Director}

U.S. Geological Survey, Reston, Virginia: 2006

For sale by U.S. Geological Survey, Information Services
Box 25286, Denver Federal Center
Denver, CO 80225
For more information about the USGS and its products:
Telephone: 1-888-ASK-USGS
World Wide Web: http://www.usgs.gov/

Any use of trade, product, or firm names in this publication is for descriptive purposes only and does not imply endorsement by the U.S. Government.

Although this report is in the public domain, permission must be secured from the individual copyright owners to reproduce any copyrighted materials contained within this report.

Suggested citation:

Sullivan, A.B., and Rounds, S.A., 2006, Modeling water quality effects of structural and operational changes to

Scoggins Dam and Henry Hagg Lake, Oregon: U.S. Geological Survey Scientific Investigations Report 2006-5060, 36 p. 


\section{Contents}

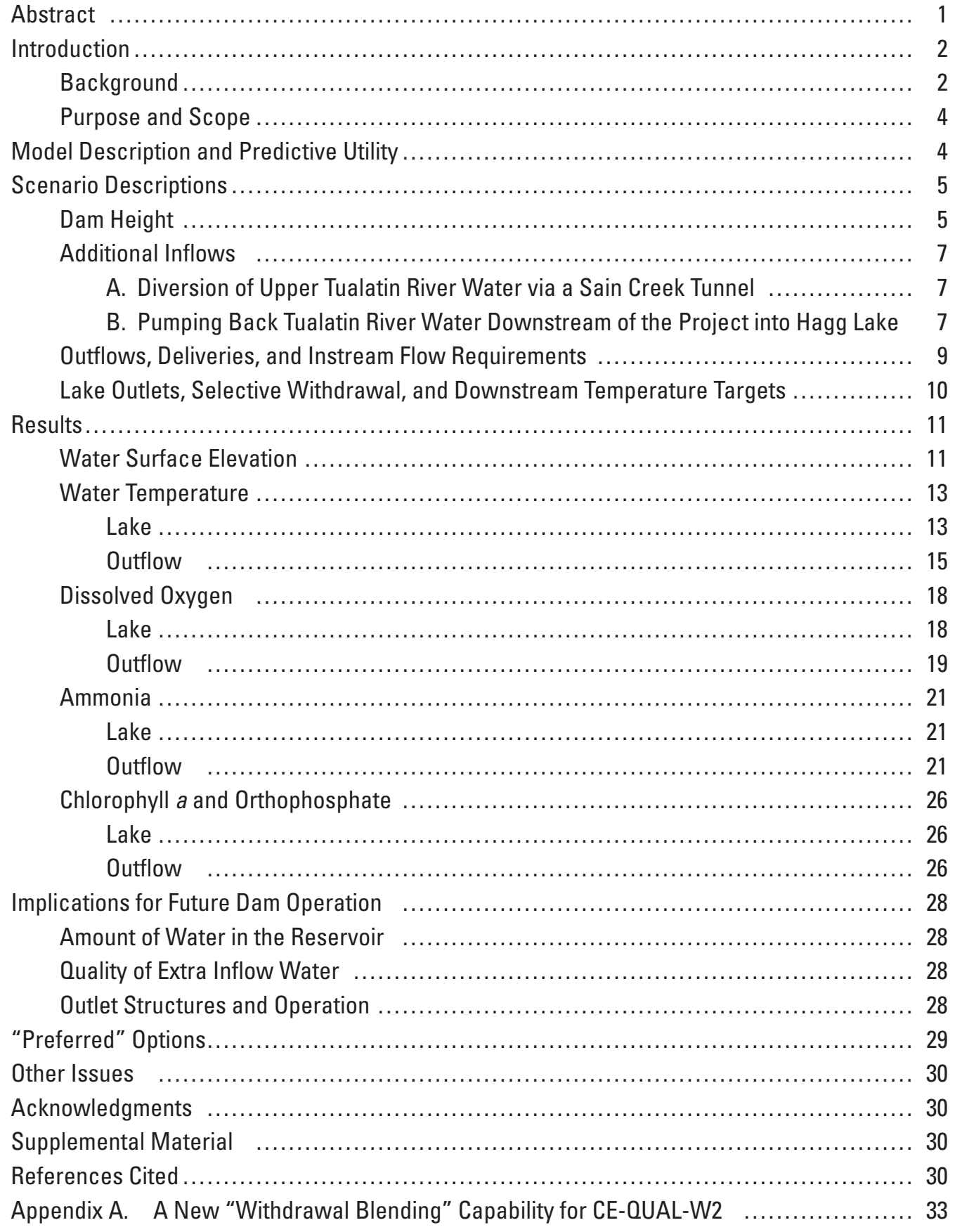




\section{Figures}

Figure 1. Map showing Henry Hagg Lake, Oregon, and surrounding area $\ldots \ldots \ldots \ldots \ldots \ldots \ldots$

Figure 2. Diagrams showing types of outlet assemblies tested in the dam raise scenarios,

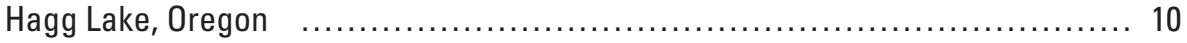

Figure 3. Graph showing Oregon's maximum water temperature standard in Scoggins

Creek downstream of the dam, the smoothed temperature target used in

model scenarios, the 7-day moving average of the daily maximum temperature

(7dADM) in Scoggins Creek upstream of the lake, and the measured

temperature in 2002 downstream of Scoggins Dam

Figure 4. Graphs showing water surface elevations for the scenarios with the relevant fill curves, Hagg Lake, Oregon, 2002

Figure 5. Graphs showing water surface elevations for the scenarios with the relevant fill curves, Hagg Lake, Oregon, 2001

Figure 6. Graphs showing simulated water temperature in the deepest part of the lake near the dam for 2002 scenarios 10b, 11b, 12b, and 13b, Hagg Lake, Oregon

Figure 7. Graphs showing simulated water temperature in the deepest part of the lake near the dam for 2002 base case (0) and pump-back scenarios (14b, 15b), Hagg Lake, Oregon

Figure 8. Graphs showing simulated water temperature in the outflow for scenarios

0, 10, 11, 12, and 13, Hagg Lake, Oregon, 2002 16

Figure 9. Graphs showing simulated water temperature in the outflow for scenarios 0, 14, and 15, Hagg Lake, Oregon, 2002

Figure 10. Graphs showing simulated dissolved oxygen concentrations in the deepest part of the lake near the dam for 2002 scenarios 10b, 11b, 12b, and 13b,

Hagg Lake, Oregon

Figure 11. Graphs showing simulated dissolved oxygen concentrations in the deepest part of the lake near the dam for 2002 base case (0) and pump-back scenarios (14b, 15b), Hagg Lake, Oregon

Figure 12. Graphs showing simulated dissolved oxygen concentrations in the outflow for scenarios 10, 11, 12, and 13, Hagg Lake, Oregon, 2002

Figure 13. Graphs showing simulated dissolved oxygen concentrations in the outflow for scenarios 0, 14, and 15, Hagg Lake, Oregon, 2002.

Figure 14. Graph showing annual whole-lake average ammonia concentration and the number of days in 2002 with dissolved oxygen concentrations anywhere in the lake less than $1 \mathrm{mg} / \mathrm{L}$, Hagg Lake, Oregon .....

Figure 15. Graphs showing simulated ammonia concentrations in the deepest part of the lake near the dam for 2002 scenarios 10b, 11b, 12b, and 13b, Hagg Lake, Oregon

Figure 16. Graphs showing simulated ammonia concentrations in the deepest part of the lake near the dam for 2002 base case (0) and pump-back scenarios (14b, 15b), Hagg Lake, Oregon

Figure 17. Graphs showing simulated ammonia concentrations in the outflow for scenarios 0, 10, 11, 12, and 13 for 2002, Hagg Lake, Oregon

Figure 18. Graphs showing simulated ammonia concentrations in the outflow for scenarios 0 , 14, and 15 for 2002, Hagg Lake, Oregon.

Figure 19. Graph showing annual average orthophosphate and chlorophyll a concentrations in the outflow, Hagg Lake, Oregon 


\section{Tables}

Table 1. Scenarios showing water delivery level, dam height, outlet type, and supplemental inflow strategy for Hagg Lake, Oregon, 2001-02

Table 2. Annual deliveries used in the model scenarios for downstream water users and instream flow requirements, Hagg Lake, Oregon $\ldots \ldots \ldots \ldots \ldots \ldots \ldots \ldots \ldots . . . \ldots$

Table 3. Whole-lake annual scenario results for water temperature and dissolved

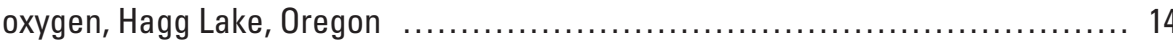

Table 4. Annual scenario results for the outflow from Hagg Lake, Oregon ................. 17

Table 5. In-lake annual scenario results for ammonia, orthophosphate, chlorophyll $a$, and blue-green algae, Hagg Lake, Oregon

\section{Conversion Factors, Datums, Abbreviations, and Acronyms}

Inch/Pound to SI

\begin{tabular}{lcl}
\hline Multiply & By & To obtain \\
\hline acre-foot $($ acre-ft) & 1,233 & cubic meter \\
cubic foot $\left(\mathrm{ft}^{3}\right)$ & 0.02832 & cubic meter \\
cubic foot per second $\left(\mathrm{ft}^{3} / \mathrm{s}\right)$ & 0.02832 & cubic meter per second \\
foot $(\mathrm{ft})$ & 0.3048 & meter \\
mile (mi) & 1.609 & kilometer \\
square foot $\left(\mathrm{ft}^{2}\right)$ & 0.09290 & square meter \\
square mile $\left(\mathrm{mi}^{2}\right)$ & 2.590 & square kilometer \\
\hline
\end{tabular}

SI to Inch/Pound

\begin{tabular}{lll}
\hline Multiply & By & To obtain \\
\hline gram per cubic meter $\left(\mathrm{g} / \mathrm{m}^{3}\right)$ & 0.002 & pound per cubic foot \\
meter $(\mathrm{m})$ & 3.281 & foot \\
\hline
\end{tabular}

Temperature in degrees Celsius $\left({ }^{\circ} \mathrm{C}\right)$ may be converted to degrees Fahrenheit $\left({ }^{\circ} \mathrm{F}\right)$ as follows:

$$
{ }^{\circ} \mathrm{F}=\left(1.8 \times{ }^{\circ} \mathrm{C}\right)+32 .
$$

Specific conductance is given in microsiemens per centimeter at 25 degrees Celsius $(\mu \mathrm{S} / \mathrm{cm}$ at $\left.25^{\circ} \mathrm{C}\right)$.

Concentrations of chemical constituents in water are given either in milligrams per liter (mg/L) or micrograms per liter $(\mu \mathrm{g} / \mathrm{L})$.

Datums

Vertical coordinate information is referenced to the National Geodetic Vertical Datum of 1929 (NGVD 29).

Horizontal coordinate information is referenced to the North American Datum of 1927 (NAD 27). 


\section{Conversion Factors, Datums, Abbreviations, and Acronyms- Continued}

Abbreviations and Acronyms

\begin{tabular}{ll}
\hline \multicolumn{1}{c}{$\begin{array}{c}\text { Abbreviation or } \\
\text { Acronym }\end{array}$} & \multicolumn{1}{c}{ Definition } \\
\hline CWS & Clean Water Services \\
EIS & Environmental Impact Statement \\
JWC & Joint Water Commission \\
LO & Lake Oswego Corporation \\
RMSE & root mean square error \\
$\mathrm{N}$ & nitrogen \\
$\mathrm{P}$ & phosphorus \\
SD & standard deviation \\
TVID & Tualatin Valley Irrigation District \\
USGS & U.S. Geological Survey \\
7dADM & 7-day running average of the daily maximum \\
\hline
\end{tabular}




\title{
Modeling Water Quality Effects of Structural and Operational Changes to Scoggins Dam and Henry Hagg Lake, Oregon
}

\author{
By Annett B. Sullivan and Stewart A. Rounds
}

\section{Abstract}

To meet water quality targets and the municipal and industrial water needs of a growing population in the Tualatin River Basin in northwestern Oregon, an expansion of Henry Hagg Lake is under consideration. Hagg Lake is the basin's primary storage reservoir and provides water during western Oregon's typically dry summers. Potential modifications include raising the dam height by 6.1 meters (20 feet), 7.6 meters (25 feet), or 12.2 meters (40 feet); installing additional outlets (possibly including a selective withdrawal tower); and adding additional inflows to provide greater reliability of filling the enlarged reservoir. One method of providing additional inflows is to route water from the upper Tualatin River through a tunnel and into Sain Creek, a tributary to the lake. Another option is to pump water from the Tualatin River (downstream of the lake) uphill and into the reservoir during the winter-the "pump-back" option. A calibrated CE-QUAL-W2 model of Henry Hagg Lake's hydrodynamics, temperature, and water quality was used to examine the effect of these proposed changes on water quality in the lake and downstream. Most model scenarios were run with the calibrated model for 2002, a typical water year; a few scenarios were run for 2001, a drought year.

Significant findings:

- The proposed dam raise and associated changes to the lake's inflows and releases are likely to produce important and measurable changes in water quality, both in the lake and in the water released downstream to Scoggins Creek.

- Compared with the base case (measured conditions), most modifications considered in these scenarios led to cooler annual average water temperatures, less hypolimnetic anoxia, and lower annual average concentrations of ammonia and chlorophyll $a$.

- The amount of water withdrawn from Hagg Lake has water quality implications. Model scenarios with low water levels produced warmer lake temperatures, earlier turnover and higher ammonia concentrations in the hypolimnion compared with scenarios having higher water levels. In the outflow, low lake levels led to more frequent exceedance of downstream temperature criteria in the absence of outlet modifications.

- Either diverting upper Tualatin River water through a Sain Creek tunnel or pumping back downstream Tualatin River water would fill an enlarged Hagg Lake [7.6 meter (25 foot) and 12.2 meter (40 foot) dam raises] in 2002. In a drought year such as 2001, however, pump-back would not necessarily fill the enlarged lake, as water levels would be low at the start of the year, and drought conditions would reduce the availability of water in the Tualatin River downstream.

- Simulations of the wintertime transfer of water into Hagg Lake from the Tualatin River via pump-back resulted in increased phosphorus concentrations in the lake, especially in 2002 due in part to high concentrations of orthophosphate in the pump-back water that year.

- Water temperature criteria in Scoggins Creek downstream of Scoggins Dam will likely not be met without modifications, such as the construction of additional lake outlets to allow the blending of warm and cold water from various depths in the lake.

- Model predictions indicate that blending water from near the lake's surface (typically warm in the summer) with water from near the lake bottom (typically cold) would be sufficient to meet downstream temperature criteria and restore a more natural seasonal temperature pattern in Scoggins Creek below the dam. A selective withdrawal tower with sliding gates or multiple fixed outlets would offer dam operators the necessary flexibility for blending.

- The use of multiple lake outlets and various operational strategies has important effects on water quality in the lake. Hypolimnetic anoxia and the subsequent buildup of hypolimnetic ammonia can be minimized or avoided. Lake surface temperature maxima can be decreased, which may help to minimize blooms of the blue-green algae Anabaena planctonica. 


\section{Introduction}

\section{Background}

Henry Hagg Lake (Hagg Lake) is a man-made reservoir in the Coast Range mountains of the Tualatin River Basin, west of the Portland metropolitan area in northwestern Oregon (fig. 1). The lake was formed by the construction of Scoggins Dam, an earthfill structure that impounds Scoggins Creek, a tributary to the Tualatin River. Besides Scoggins Creek, Sain and Tanner Creeks also flow into Hagg Lake. The reservoir filled and began operation in 1975. At the current full-pool

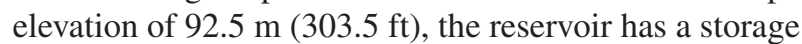
capacity of 62,216 acre-ft and a surface area of $1.7 \mathrm{mi}^{2}$ (Ferrari, 2001).

Hagg Lake is the major water storage facility in the Tualatin River Basin. It is used for recreation, flood control, flow augmentation in the lower Tualatin River, and as a source of municipal, industrial, and agricultural water. Twelve cities, with a current combined population of 460,000 , lie in the basin. Their populations and associated water needs are projected to approximately double by the year 2050 (Montgomery Watson Harza, 2004). Current municipal water needs are met with multiple water supply sources, including ground water and surface water, and importation of water from the Trask River to the west and the City of Portland's Bull Run River water supply to the east. Due to rising demand, however, future water needs will not be met by the current water supply system.

A host of options has been considered to meet future water demands, several of which include structural, operational and inflow changes to Hagg Lake. Options include raising the dam height by $6.1 \mathrm{~m}(20 \mathrm{ft}), 7.6 \mathrm{~m}(25 \mathrm{ft})$,

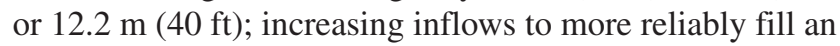
enlarged reservoir; and installing other lake outlets, perhaps including a selective withdrawal tower. The additional inflows may be obtained by routing water from the upper Tualatin River near Haines Falls into the reservoir via a tunnel that discharges to Sain Creek, or by pumping water uphill and into the reservoir (pump-back water), from the Tualatin River at the Springhill Pumping Plant via a pipeline during winter high flows.

Water releases from an enlarged reservoir would change to meet increased downstream demands and updated instream flow requirements for Scoggins Creek below the lake. Some future outflows may be routed directly from the reservoir through a pipeline to the water treatment plant for municipal and industrial users. The installation of additional lake outlets, or a selective withdrawal tower, would allow water to be blended and released from different lake depths (with different temperatures and water quality) to meet downstream water temperature or water quality targets.

Water quality in Hagg Lake was documented and simulated with a model by the U.S. Geological Survey (USGS) (Sullivan and Rounds, 2005). The model was calibrated for the years 2000-03, a period that included a drought year (2001) in which the lake did not fill. The model successfully simulated the lake's heat budget and captured the important components of processes affecting water quality, focusing primarily on nitrogen, phosphorus, algae, and dissolved oxygen. Water temperature was simulated with a root mean square error (RMSE) of less than $1^{\circ} \mathrm{C}$, and dissolved oxygen was simulated with a typical RMSE less than $1 \mathrm{mg} / \mathrm{L}$, measures which indicate that the model accurately simulated the dynamics and seasonal variations in the lake's water quality.

Hagg Lake exhibits several annual limnological cycles. Each year, as the lake surface warms through the springtime, a thermocline develops in the lake by early summer. This thermal gradient isolates cold and dense water within the reservoir's lower layer. As the summer progresses, dissolved oxygen in this lower layer of water (the hypolimnion) is consumed, typically leading to anoxia (no oxygen) by late September. At the onset of anoxia, ammonia begins to accumulate in the hypolimnion. As surface water temperatures cool in autumn, the temperature stratification eventually is eliminated and the lake mixes and reoxygenates, generally in mid-November; this vertical mixing is termed lake turnover. Moderate algal blooms (about $20 \mu \mathrm{g} / \mathrm{L}$ chlorophyll $a$ ), including a blue-green algae bloom in August, typically occur every year in Hagg Lake and influence the lake's water quality. The seasonal temperature pattern of outflows from Hagg Lake is characteristically different from that of the tributaries to the lake, and the outflows occasionally exceed the downstream water temperature criteria. Water with low dissolved oxygen concentrations also is predicted to be released in autumn, but efficient aeration of that water by turbulence at the foot of the dam prevents violations of the minimum dissolved oxygen standard (Sullivan and Rounds, 2005). 
The effect of the proposed structural, inflow, and operational changes on reservoir and outflow water quality can be evaluated before such changes are made. Issues of concern include temperature, dissolved oxygen, ammonia, and algae in the lake and in the outflows, including water released to Scoggins Creek and water delivered to downstream users via a proposed pipeline. In this investigation, the USGS Hagg
Lake model was used to simulate the effects of these proposed structural changes on the quality of the lake and the water released from it.

This investigation resulted from a scientific and financial partnership between the USGS and Clean Water Services (CWS), one of a group of agencies investigating the various options for meeting future water-supply needs in the Tualatin River Basin.

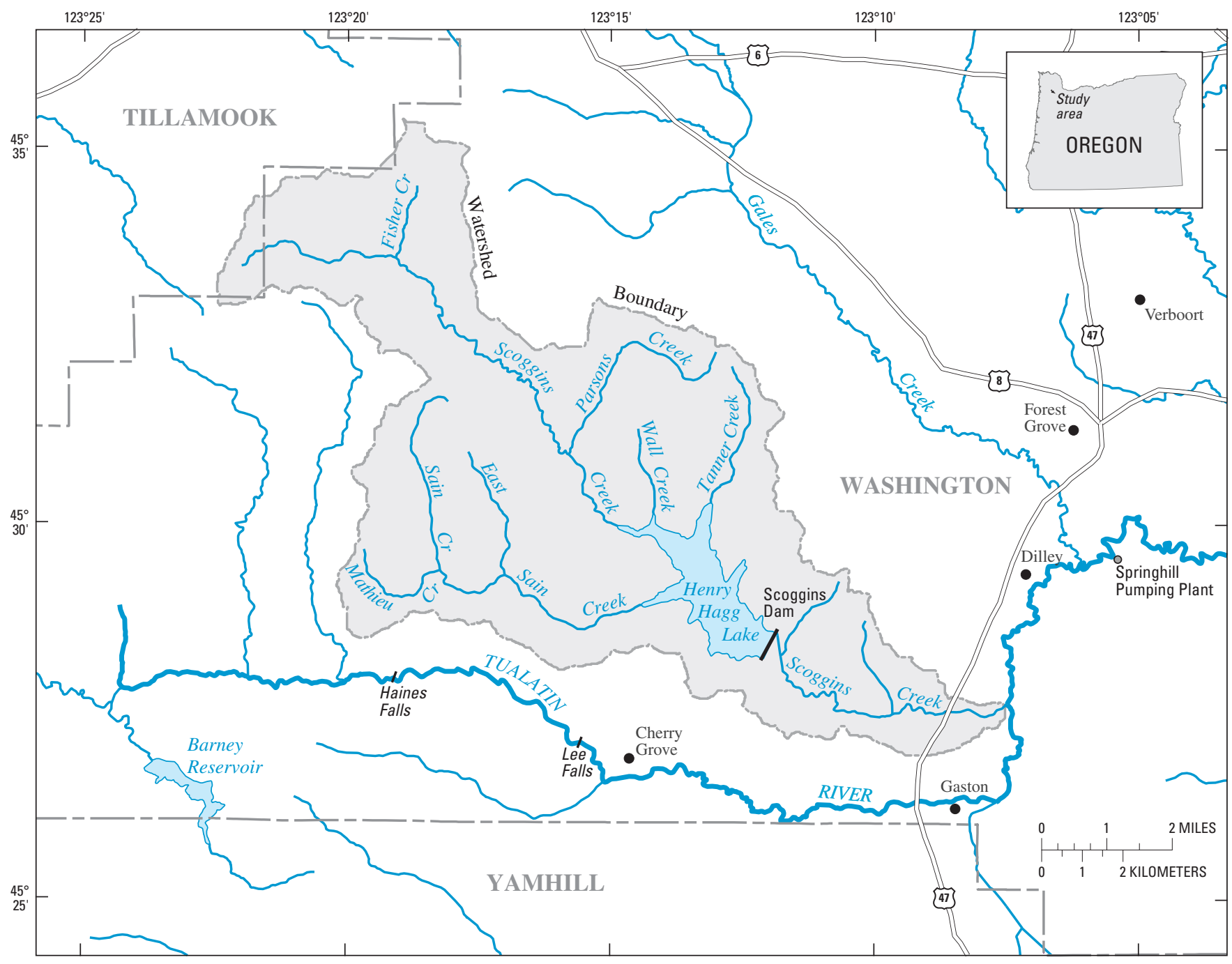

Figure 1. Henry Hagg Lake, Oregon, and surrounding area. 


\section{Purpose and Scope}

The purpose of this study was to develop a model of Hagg Lake that could (1) simulate lake hydrodynamics, temperature, and water quality; (2) help develop an understanding of the processes affecting hydrodynamics, temperature and water quality; and (3) predict changes in hydrodynamics, temperature and water quality that could result from a set of proposed modifications to the dam and lake. A previous report (Sullivan and Rounds, 2005) addressed the first two goals, and this report addresses the third by summarizing model results for hydrodynamics, temperature, and water quality under different structural, operational, and inflow conditions. The calibrated USGS Hagg Lake model for the year 2002, a normal hydrologic year, was used as the basis for most of the scenarios. Some scenarios were repeated for 2001, a drought year.

The model scenarios included combinations of the following elements:

1. Dam height

- Raise dam by $6.1 \mathrm{~m}(20 \mathrm{ft})$

- Raise dam by $7.6 \mathrm{~m}(25 \mathrm{ft})$

- Raise dam by $12.2 \mathrm{~m}$ (40 ft)

2. Water deliveries from dam

- Initial water deliveries just after dam construction (low deliveries)

- Future maximum water deliveries after dam construction (high deliveries)

3. Inflow modification

- Add inflow from the upper Tualatin River via a Sain Creek tunnel (low flow rate)

- Add inflow from the upper Tualatin River via a Sain Creek tunnel (high flow rate)

- Add pump-back inflow from the Tualatin River downstream of the project

4. Outlet configuration

- Existing outlet only

- Existing outlet plus a second fixed-elevation outlet

- Existing outlet plus a variable-elevation outlet

- Remove existing outlet; add one variable-elevation outlet

Scenario results were analyzed with regard to the water quality of the lake, the quality of water withdrawn from the lake, and the type and placement of outlet structures.
For the lake itself, analyses focused on thermal structure, ammonia and orthophosphate concentrations, algal population dynamics, and the extent, timing, and duration of hypolimnetic anoxia. The quality of released water in the model was analyzed with regard to water temperature, dissolved oxygen, ammonia, orthophosphate, chlorophyll $a$, and the downstream water temperature criteria in Scoggins Creek. The effect of various outlet structures and water blending schemes on lake and downstream water quality also was analyzed. These results can be used to help determine how modifications to the dam and reservoir might be designed and managed to optimize water quality.

\section{Model Description and Predictive Utility}

The construction, calibration, and testing of the USGS Hagg Lake model was documented by Sullivan and Rounds (2005). In short, the two-dimensional, laterally averaged model CE-QUAL-W2 version 3.12 (Cole and Wells, 2002) was applied to Hagg Lake for the years 2000 through 2003. The lake model grid was constructed by combining a bathymetric coverage of the current lake with a topographic coverage of the surrounding area, so that both the current lake and an enlarged lake could be modeled. Lake hydrodynamics, water temperature, orthophosphate, total phosphorus, ammonia, algae (2 groups), chlorophyll $a$, zooplankton, and dissolved oxygen were modeled, calibrated, and tested with measured lake data. Other modeled constituents included dissolved and particulate organic matter, nitrate, dissolved solids, and suspended sediment; these constituents were included in the model because of their importance to the cycles of other constituents, but were not calibrated due to a lack of data. The model accurately captured the most important seasonal and spatial influences on lake water quality.

Most model scenarios described in this report were based on the Hagg Lake model using conditions from 2002, a typical hydrologic year. Some scenario simulations also were run for 2001, a drought year. Model scenarios were run by modifying the dam height, adjusting inflows and outflows, and adding new lake outlet structures. Such changes were superimposed on the previously calibrated model for 2001 or 2002.

Although the USGS Hagg Lake model was constructed and calibrated for existing conditions, it should be able to make useful predictions of the hydrodynamic, thermal, and water quality changes resulting from a dam raise.

CE-QUAL-W2 has been applied to hundreds of reservoir systems around the world (Cole and Wells, 2002). Those applications have demonstrated that when the model is provided with accurate bathymetric data, a balanced water budget, and good meteorological data, it will accurately 
simulate the heat budget and temperature dynamics of the system, including the timing of the onset of stratification and lake turnover in autumn. The physics of heat transfer processes are well known and have been translated into accurate mathematical algorithms in CE-QUAL-W2. Past performance and recent USGS applications of this model demonstrate its success in simulating water temperature in reservoir and river systems (Bales and others, 2001; Green, 2001; Rounds and Wood, 2001; Sullivan and Rounds, 2004; Sullivan and Rounds, 2005). As in the calibrated model, temperature predictions are expected to be accurate to within $1^{\circ} \mathrm{C}$ or less as a root mean square error.

Similarly, as long as the water quality algorithms in CE-QUAL-W2 capture the most important processes affecting water quality in the lake, and as long as the expanded lake's water quality is controlled by those same processes, the model's water quality predictions should be useful and relatively accurate. The most important processes affecting dissolved oxygen in the existing system are water temperature and sediment oxygen demand, with minor influences from the algal community (Sullivan and Rounds, 2005). Ammonia concentrations are controlled primarily by the presence, duration, and extent of hypolimnetic anoxia. Phosphorus concentrations are affected primarily by inflows, algal uptake, and hypolimnetic anoxia. None of these influences are likely to change greatly in an expanded lake, although inputs and outputs differ between scenarios.

The greatest uncertainty in the model's predictions for an expanded lake likely will revolve around the lake's algal communities. The first issue is that only limited algae and chlorophyll $a$ data were available to calibrate the Hagg Lake model. Although sampling of the lake occurred regularly and species distributions were determined, the lake was sampled at only one location and at one depth near the surface, and no samples of the outflow were taken; thus the testing of the model's ability to simulate measured algal dynamics was somewhat limited. For instance, some algae grow best near the thermocline with the lower oxygen and higher carbon dioxide and nutrient concentrations (Horne and Goldman, 1994). Secondly, the model's representation of algae is a necessary simplification of the real system. Although more than 80 species of algae were identified in Hagg Lake for the years modeled, the calibrated model separated that community into only two algal groups, one of blue-green algae and one representing all other algae (Sullivan and Rounds, 2005). To simulate more groups would require more data on growth rates, settling rates, and other group-specific parameters that were not available for Hagg Lake. The model was calibrated specifically to try to capture the timing and extent of the lake's annual late-summer bloom of blue-green algae (typically Anabaena planctonica). The modeling team focused on that bloom because blue-green algae can produce toxins and often are associated with taste and odor issues in drinking-water supplies. Finally, the Hagg Lake models were run on an annual timescale, and were not designed to examine possible longer term algal species shifts following a system perturbation such as a dam raise.

Despite these limitations, changes in the algal community in an expanded lake would likely be due to influences that the model already captures with good accuracy: water temperature, light conditions, and nutrient concentrations. Model predictions of the algal community's response to a dam raise must be viewed as an informed estimate that can be used to direct future planning and research.

\section{Scenario Descriptions}

A total of 36 model scenarios, including the 2001 and 2002 base cases, were run to examine the effect of three dam raises, two water delivery levels, various outlet configurations, and two schemes for augmenting inflows to Hagg Lake. These scenarios are summarized in table 1.

\section{Dam Height}

Increases in dam height of $6.1 \mathrm{~m}(20 \mathrm{ft}), 7.6 \mathrm{~m}(25 \mathrm{ft})$, and $12.2 \mathrm{~m}$ (40 ft) resulted in simulated full-pool total storages of $88,800,95,800$, and 118,000 acre-ft, respectively, with the Hagg Lake model grid. The simulated base case storage at full pool was 63,900 acre-ft (slightly larger than the Bureau of Reclamation's reported full-pool storage of 62,216 acre-ft). These increases in dam height required the determination of new "fill curves," the targeted daily lake elevations used to optimize reservoir operation. This curve requires water levels to be below full pool in winter to provide for 20,600 acre-ft of available storage for flood control. The fill curve then specifies an increase in water level through May to reach full pool, thereby maximizing water availability for summertime withdrawals. Three new fill curves were generated based on the current Hagg Lake fill curve. The maximum elevation of the fill curve was increased by $6.1,7.6$, or $12.2 \mathrm{~m}(20,25$, or $40 \mathrm{ft}$ ), and the minimum (winter) fill curve elevation was determined as the lake elevation that provides space for 20,600 acre-ft of flood control storage.

In order to fill the increased volume of an enlarged reservoir, all or part of the water (above deliveries and instream flow requirements) released from the reservoir in December of the previous year to make room for flood control storage was kept in the reservoir. This resulted in an initial (January 1) water surface elevation that was $2.1 \mathrm{~m}$ higher than the 2002 base case for all scenarios involving a dam raise (but without augmented inflows). For 2001, the drought year, keeping the excess spilled water from late 2000 only raised the water surface elevation by $0.02 \mathrm{~m}$ (late 2000 was fairly dry). In the model runs, water was spilled from the reservoir when the water surface elevation reached the applicable fill curve, thus keeping the water level from exceeding the fill curve. 
Table 1. Scenarios showing water delivery level, dam height, outlet type, and supplemental inflow strategy for Hagg Lake, Oregon, $2001-02$.

[Scenarios with two outlets of any type or one variable-elevation outlet have selective-withdrawal capability]

\begin{tabular}{|c|c|c|c|c|c|c|c|c|}
\hline \multirow{2}{*}{\multicolumn{2}{|c|}{ Scenario }} & \multirow{3}{*}{$\begin{array}{c}\text { Water } \\
\text { deliveries }\end{array}$} & \multirow{3}{*}{$\begin{array}{l}\text { Dam raise } \\
\text { (feet) }\end{array}$} & \multicolumn{3}{|c|}{ Outlets } & \multirow[b]{2}{*}{$\begin{array}{l}\text { Sain Creek Tunnel } \\
\text { inflow rate }\end{array}$} & \multirow{3}{*}{$\begin{array}{c}\text { Tualatin River } \\
\text { pump-back }\end{array}$} \\
\hline & & & & $\begin{array}{l}\text { Existing } \\
\text { fixed- } \\
\text { elevation }\end{array}$ & $\begin{array}{c}\text { Additional } \\
\text { fixed- } \\
\text { elevation }\end{array}$ & $\begin{array}{l}\text { Variable- } \\
\text { elevation }\end{array}$ & & \\
\hline \multicolumn{6}{|r|}{2002} & & & \\
\hline 0 & Base & Measured & 0 & $x$ & & & & \\
\hline \multirow{2}{*}{1} & $\mathrm{a}$ & Initial & 20 & $x$ & & & & \\
\hline & $\mathrm{b}$ & Maximum & 20 & $x$ & & & & \\
\hline \multirow{2}{*}{2} & $\mathrm{a}$ & Initial & 20 & $x$ & & $x$ & & \\
\hline & $\mathrm{b}$ & Maximum & 20 & $x$ & & $\times$ & & \\
\hline \multirow{2}{*}{3} & $\mathrm{a}$ & Initial & 20 & $x$ & $x$ & & & \\
\hline & $\mathrm{b}$ & Maximum & 20 & $x$ & $x$ & & & \\
\hline \multirow{2}{*}{4} & $\mathrm{a}$ & Initial & 20 & & & $x$ & & \\
\hline & $\mathrm{b}$ & Maximum & 20 & & & $x$ & & \\
\hline \multirow{2}{*}{5} & $\mathrm{a}$ & Initial & 40 & $x$ & & & & \\
\hline & $\mathrm{b}$ & Maximum & 40 & $x$ & & & & \\
\hline \multirow{2}{*}{6} & $\mathrm{a}$ & Initial & 40 & $x$ & & $x$ & & \\
\hline & $\mathrm{b}$ & Maximum & 40 & $x$ & & $x$ & & \\
\hline \multirow{2}{*}{7} & $\mathrm{a}$ & Initial & 40 & $x$ & $x$ & & & \\
\hline & $\mathrm{b}$ & Maximum & 40 & $x$ & $x$ & & & \\
\hline \multirow{2}{*}{8} & $\mathrm{a}$ & Initial & 40 & & & $x$ & & \\
\hline & $\mathrm{b}$ & Maximum & 40 & & & $x$ & & \\
\hline \multirow{2}{*}{9} & $\mathrm{a}$ & Initial & 40 & $x$ & & & Low & \\
\hline & $\mathrm{b}$ & Maximum & 40 & $x$ & & & Low & \\
\hline \multirow{2}{*}{10} & $\mathrm{a}$ & Initial & 40 & $x$ & & & High & \\
\hline & $\mathrm{b}$ & Maximum & 40 & $x$ & & & High & \\
\hline \multirow{2}{*}{11} & $\mathrm{a}$ & Initial & 40 & $x$ & & $x$ & High & \\
\hline & $\mathrm{b}$ & Maximum & 40 & $x$ & 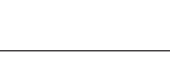 & $x$ & High & \\
\hline \multirow{2}{*}{12} & $\mathrm{a}$ & Initial & 40 & $x$ & $x$ & & High & \\
\hline & $\mathrm{b}$ & Maximum & 40 & $x$ & $x$ & & High & \\
\hline \multirow{2}{*}{13} & $\mathrm{a}$ & Initial & 40 & & & $x$ & High & \\
\hline & $\mathrm{b}$ & Maximum & 40 & & & $x$ & High & \\
\hline \multirow{2}{*}{14} & $\mathrm{a}$ & Initial & 40 & $x$ & & $x$ & & $x$ \\
\hline & $\mathrm{b}$ & Maximum & 40 & $x$ & & $x$ & & $x$ \\
\hline \multirow{2}{*}{15} & $\mathrm{a}$ & Initial & 25 & $x$ & & $x$ & & $x$ \\
\hline & $\mathrm{b}$ & Maximum & 25 & $x$ & & $x$ & & $x$ \\
\hline \multicolumn{9}{|c|}{2001} \\
\hline 0 & Base & Measured & 0 & $x$ & & & & \\
\hline \multirow{2}{*}{14} & $\mathrm{a}$ & Initial & 40 & $x$ & & $x$ & & $x$ \\
\hline & $\mathrm{b}$ & Maximum & 40 & $x$ & & $x$ & & $x$ \\
\hline \multirow{2}{*}{15} & $\mathrm{a}$ & Initial & 25 & $x$ & & $x$ & & $x$ \\
\hline & $\mathrm{b}$ & Maximum & 25 & $x$ & & $x$ & & $x$ \\
\hline
\end{tabular}




\section{Additional Inflows}

According to one analysis, although a $12.2 \mathrm{~m} \mathrm{(40 \textrm {ft } )}$ increase in the height of Scoggins Dam provides sufficient storage, unaugmented inflows into the lake would meet future water demands in only about 20 percent of years (Ryan Murdock, Montgomery Watson Harza, written commun., 2005). Therefore, two additional sources of inflow water are considered in this study in an attempt to more reliably fill the enlarged lake created by the larger [12.2 and $7.6 \mathrm{~m}$ (40 and $25 \mathrm{ft}$ )] dam raises. Additional inflows were not provided in

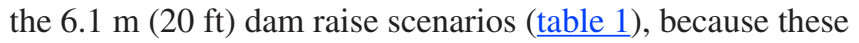
scenarios were only run for year 2002, when there was enough natural flow to fill that reservoir size.

\section{A. Diversion of Upper Tualatin River Water via a Sain Creek Tunnel}

One option to augment inflows to Hagg Lake is to use water in the upper Tualatin River and route it via gravity through a tunnel into Sain Creek, a tributary of Hagg Lake. Available water would be defined as the amount that is above both the Tualatin River's environmental needs and downstream water users' needs. The water would be diverted from Hillsboro Reservoir on the Tualatin River, at approximately the same location as Haines Falls [river mile (RM) 73.3, fig. 1]. The length of the tunnel would be between 2.8 and $3.9 \mathrm{mi}$.

Model scenarios were completed with two flow schedules for the tunnel: "low" and "high" inflow. The low inflow version would use available water after considering water rights. In these scenarios, the diversion was $150 \mathrm{ft}^{3} / \mathrm{s}$ in December and January, $120 \mathrm{ft}^{3} / \mathrm{s}$ in February, and $60 \mathrm{ft}^{3} / \mathrm{s}$ in March, corresponding to a total diversion of approximately 28,800 acre-ft. The high inflow schedule would use water availability plus a portion of "natural flow" water rights allowed to the Joint Water Commission, a consortium of Tualatin River Basin water providers. This would divert $250 \mathrm{ft}^{3} / \mathrm{s}$ in December and January, $220 \mathrm{ft}^{3} / \mathrm{s}$ in February, and $160 \mathrm{ft}^{3} / \mathrm{s}$ in March, for a total of 52,800 acre-ft (Tom VanderPlaat, Clean Water Services, written commun., 2005). In these scenarios, the Sain Creek tunnel was used from January through March.

In addition to these winter inflows, which would help fill the reservoir, water released from Barney Reservoir (fig. 1) to the upper Tualatin River in summer was modeled to be routed into Hagg Lake via the Sain Creek tunnel but not kept in the lake; an identical flow was released from Hagg Lake. This arrangement allowed the water released from Barney Reservoir to be discharged into future pipelines connected to the Scoggins Dam outlet works. The amount of these Barney Reservoir releases/inflows were obtained from the annual flow reports for the appropriate year (Tualatin River Flow Management Technical Committee, 2001; 2002). These flows generally occurred between early June and mid-November and ranged from 14 to $54 \mathrm{ft}^{3} / \mathrm{s}$.
Water temperatures assigned to Sain Creek tunnel flows for 2002 were taken from measurements in the Tualatin River from below Lee Falls (RM 70.5). Besides temperature, no other water quality data were collected there, so data from Cherry Grove (RM 67.8) on the upper Tualatin River were used. Water of this composition was mixed together with Sain Creek water to obtain a mixed flow, temperature, and water quality input from Sain Creek for the simulations with the new inflows. The Lee Falls water temperatures were similar to Sain Creek temperatures for most of the year, but as much as $4^{\circ} \mathrm{C}$ cooler in August and September. The upper Tualatin River water may be cooler in part due to releases from Barney Reservoir upstream. The conductivity of upper Tualatin River water was lower in summer, by as much as $40 \mu \mathrm{S} / \mathrm{cm}$, probably for the same reason. Dissolved oxygen concentrations usually were higher (by about $1 \mathrm{mg} / \mathrm{L}$ ) through most of the year, and nitrite/nitrate concentrations were approximately $0.1 \mathrm{mg} / \mathrm{L}$ lower in the upper Tualatin River. Orthophosphate concentrations in both waters were similar.

\section{B. Pumping Back Tualatin River Water Downstream of the Project into Hagg Lake}

Another proposed method of augmenting inflows to Hagg Lake during the winter is to pump water into the lake from downstream. This method would take advantage of a proposed pipeline connecting Scoggins Dam to the Joint Water Commission's (JWC) drinking water treatment plant south of Forest Grove. The main purpose of that pipeline would be to efficiently deliver water from Hagg Lake to the drinking water treatment plant via gravity during summer months when JWC requires water from the lake. CWS also may use the pipeline to transport some of its flow-augmentation water.

This pump-back option proposes to run the pipeline in reverse during the winter (December to May) using the Tualatin Valley Irrigation District's (TVID) equipment at its Springhill Pumping Plant (RM 56.1, fig. 1) to draw water from the Tualatin River and pump it uphill through the pipeline and into Hagg Lake. The Springhill Pumping Plant is located adjacent to the JWC drinking water treatment plant; both TVID and JWC currently draw water from the Tualatin River at that location. The TVID pumps are not used in the winter due to the lack of irrigation demands, so they could be used for pump-back.

In this pump-back scenario, available flows in the Tualatin River could be delivered to Hagg Lake via the TVID pumping array and the JWC pipeline. Modeling studies of this option by Montgomery Watson Harza (Ryan Murdock, written commun., 2005) considering the capacity of the pipe, the size of the pumps, competing needs for the pipeline and pumps, and minimum Tualatin River streamflows, resulted in the following constraints on pump-back water: 
- The pipeline may be used in pump-back mode from December 1 to the end of May, if necessary. Maximum pump-back rates in May would be reduced to avoid conflicts with the use of TVID's pumps at the beginning of the irrigation season.

- Pump-back would occur only if monthly inflows to Hagg Lake were less than 30,000 acre-ft in December; 22,000 acre-ft in January; 25,000 acre-ft in February; and 25,000 acre-ft in March for the $12.2 \mathrm{~m}$ $(40 \mathrm{ft})$ dam raise. For the $7.6 \mathrm{~m}(25 \mathrm{ft})$ dam raise, the monthly inflow cutoffs were 20,000 acre-ft in December; 18,000 acre-ft in January and February; and 16,000 acre-ft in March. Although monthly totals were the constraint, all decisions on whether pumping would occur were made on a daily basis to better represent an actual operational strategy.

- Pump-back would occur only if lake stage were less than a target level —essentially a fill curve for pumping. For the $12.2 \mathrm{~m}(40 \mathrm{ft})$ dam raise, the pump-back target fill curve was created from the actual fill curve by allowing an extra 30,000 acre-ft of unused storage on December 15; 21,000 acre-ft on January 15; 6,000 acre-ft on February 15; 1,000 acre-ft on March 15; and 0 acre-ft on April 15. For the $7.6 \mathrm{~m}$ ( $25 \mathrm{ft}$ ) dam raise, the pump-back target fill curve was created by allowing an extra 40,000 acre-ft of unused storage on December 15; 35,000 acre-ft on January 15; 8,000 acre-ft on February 15; 4,000 acre-ft on March 15; and 2,000 acre-ft on April 15. This analysis was done on a daily basis, by using a smoothed target fill curve based on these points. If lake stage exceeded the target fill curve, pumping was not used, and water was spilled to meet the target fill curve. If the lake stage was less than the target level for pumping, pumping could occur.

- The maximum pump rate for the $12.2 \mathrm{~m}$ (40 ft) dam raise scenarios was $330 \mathrm{ft}^{3} / \mathrm{s}$ from December through February; $300 \mathrm{ft}^{3} / \mathrm{s}$ in March; $200 \mathrm{ft}^{3} / \mathrm{s}$ in April; and

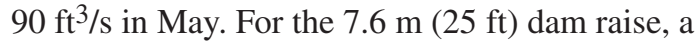
smaller pipeline was simulated with maximum delivery rates of $200 \mathrm{ft}^{3} / \mathrm{s}$ from December through April and $90 \mathrm{ft}^{3} / \mathrm{s}$ in May. The rates were dictated by the size of the pumps, the capacity of the pipeline, and competing demands for the pumps by TVID.

- Portions of JWC and TVID natural flow water rights at Springhill Pumping Plant were not diverted and assumed to be unavailable for pumping to Hagg Lake. JWC entities have several water rights for diversion at Springhill Pumping Plant that total about $110 \mathrm{ft}^{3} / \mathrm{s}$, and TVID has a natural flow water right of $90 \mathrm{ft}^{3} / \mathrm{s}$ for the irrigation season. An additional $25 \mathrm{ft}^{3} / \mathrm{s}$ was unavailable for pump-back in that stretch of the Tualatin River to account for instream flow rights.
The quality of pump-back water was estimated using a flow-weighted mix of water from Gales Creek and the Tualatin River at Dilley (RM 58.8), as the pump plant is just downstream of that confluence. Total suspended solids, total phosphorus, and orthophosphate concentrations were higher in the winter of 2001-02 than the winter of 2000-01. Although these pump-back scenarios did not limit pumping during storms, it is possible that pumping might be turned off if the source Tualatin River water had excessive loads of suspended sediment, in order to minimize the importation of phosphorus and sediment into the lake and to minimize mechanical damage to the pumping equipment.

One of the concerns of the pump-back option is that Tualatin River water at the Springhill Pumping Plant probably has higher phosphorus concentrations than water that originates in the Scoggins Creek drainage upstream of Hagg Lake. This extra phosphorus load to the lake might stimulate additional algal growth in the lake during the summer, thus creating higher levels of organic matter that, in turn, could cause problematic levels of disinfection byproducts or taste or odor problems once that material is delivered to the JWC drinking water treatment plant. Model scenarios that use the pump-back option were evaluated for this effect.

Another potential concern is that pumping would import contaminants into Hagg Lake. Sampling for pesticides by the USGS at the Springhill Pumping Plant over the course of a year (88 samples from March 2002 through February 2003) showed some detections of common pesticides such as atrazine, simazine, and diazinon, but at very low concentrations $(<0.16 \mu \mathrm{g} / \mathrm{L}$; U.S. Geological Survey, unpub. data, 2002-03). None of the detections appeared to come close to their regulatory criteria for the protection of aquatic life or for drinking water. Treatment processes may further reduce or remove these materials from finished drinking water. So, although low concentrations would be imported into Hagg Lake via pumping, the concentrations do not appear to be of great concern.

Pump-back scenarios were run for 2002 and 2001 for

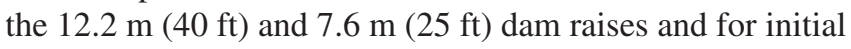
and future maximum water deliveries. Use of the pump-back option to augment inflows to Hagg Lake in these model runs was implemented in a manner consistent with the monthly inflow triggers, Tualatin River water rights, the pump-back target fill curve, and maximum pumping rates. In 2002 with the $12.2 \mathrm{~m}$ (40 ft) raise, this scenario resulted in the use of the pump-back option intermittently from December 3 to March 10 , delivering 32,100 acre-ft of water to the lake. A total of 18,400 acre-ft was spilled between January 7 and May 31, when natural inflows raised the lake level above the fill curve. In 2002 with the $7.6 \mathrm{~m}$ ( $25 \mathrm{ft}$ ) raise, pump-back occurred intermittently between December 4 and May 1, delivering 22,300 acre-ft of water to Hagg Lake. A total of 30,400 acre- $\mathrm{ft}$ was spilled between December 11 and May 31. Alternate rules for pump-back might have minimized the amount of water that was spilled in these 2002 pump-back scenarios, thereby also 
reducing the amount of water that was pumped and reducing the importation of phosphorus and other constituents from the Tualatin River downstream. These scenarios, then, can be considered as a test of those conditions that might occur if the volume of pump-back were maximized - a useful test when exploring the limits of an influence on water quality. In 2001 with the $12.2 \mathrm{~m}$ (40 ft) raise, deliveries of 25,900 acre- $\mathrm{ft}$ were made between December 1 and May 19. In 2001 with the 7.6 $\mathrm{m}(25 \mathrm{ft})$ raise, 24,000 acre-ft of water was pumped into Hagg Lake between December 1 and May 19. No spill occurred in 2001, as the lake level did not reach the fill curve.

\section{Outflows, Deliveries, and Instream Flow Requirements}

In all model scenarios, water was released from Hagg Lake to meet instream flow requirements in Scoggins Creek below the dam, to meet requirements of downstream users, and to spill excess water when lake levels rose above the fill curve. Annual deliveries for instream requirements and downstream water users are shown in table 2 for each scenario.

For the base case in 2002, minimum discharges to meet instream flow requirements in lower Scoggins Creek were $10 \mathrm{ft}^{3} / \mathrm{s}$ from December through September and $20 \mathrm{ft}^{3} / \mathrm{s}$ in October and November. New instream flow requirements would accompany a dam raise, resulting in a minimum flow of $25 \mathrm{ft}^{3} / \mathrm{s}$ through the entire year. Some of the water releases for downstream users were delivered into Scoggins Creek downstream of the dam and thus could be used to meet instream flow requirements. Other releases to downstream users (all JWC water and a portion of CWS water) were routed into the not-yet-built JWC pipeline and therefore could not be used to meet instream flow requirements. If water deliveries to Scoggins Creek for downstream customers were insufficient to meet instream flow requirements, then water was released from the lake specifically to meet those requirements. Minimum instream flows were given first priority before apportioning water to future users.

CWS, JWC, TVID, and the Lake Oswego Corporation (LO) all hold water rights to stored water in Hagg Lake. All these entities received water in the base case, but only CWS and JWC would receive additional water from an enlarged Hagg Lake. For the $12.2 \mathrm{~m}$ (40 ft) dam raise option, CWS would receive as much as an additional 15,000 acre-ft, and JWC would receive as much as an additional 37,000 acre-ft, depending on whether the lake filled. For the $6.1 \mathrm{~m} \mathrm{(20 \textrm {ft } )}$ dam raise, CWS would receive as much as an additional 6,540 acre-ft, and JWC would receive as much as an additional 16,100 acre-ft.

As lake level is known to affect water quality in Hagg Lake (Sullivan and Rounds, 2005), two levels of water deliveries to downstream users were simulated in all model runs involving a dam raise. The first level of water delivery ("a" scenarios) was characterized by lower
Table 2. Annual deliveries used in the model scenarios for downstream water users and instream flow requirements, Hagg Lake, Oregon.

[Downstream water users: TVID, Tualatin Valley Irrigation District; JWC, Joint Water Commission; CWS, Clean Water Services; LO, Lake Oswego Corporation. "Other" refers to deliveries to users such as local golf courses. In 2002, other deliveries totaled 906 acre-feet. Instream flow requirements are 10 cubic feet per second ( $\mathrm{ft}^{3} / \mathrm{s}$ ) (December-September) and $20 \mathrm{ft}^{3} / \mathrm{s}$ (October-November) for the base cases, and $25 \mathrm{ft}^{3} / \mathrm{s}$ (all year) for other scenarios. Deliveries to LO, TVID, and base case CWS could be used to meet instream flows. Instream flow values refer to additional releases necessary to meet instream requirements]

\begin{tabular}{|c|c|c|c|c|c|c|}
\hline \multirow{3}{*}{ Scenario } & \multicolumn{6}{|c|}{ Annual deliveries, in acre-feet } \\
\hline & \multicolumn{4}{|c|}{ Downstream water users } & \multirow{2}{*}{$\begin{array}{c}\text { Instream } \\
\text { flow }\end{array}$} & \multirow{2}{*}{ Total } \\
\hline & $\begin{array}{c}\text { TVID + } \\
\text { other }\end{array}$ & JWC & CWS & LO & & \\
\hline \multicolumn{7}{|c|}{2002} \\
\hline 0 & 19,900 & 8,690 & 12,600 & 496 & 3,370 & 45,100 \\
\hline $1 \mathrm{a}, 2 \mathrm{a}, 3 \mathrm{a}, 4 \mathrm{a}$ & 19,900 & 8,690 & 25,500 & 496 & 9,460 & 64,100 \\
\hline $1 b, 2 b, 3 b, 4 b$ & 27,000 & 29,600 & 19,200 & 496 & 9,290 & 85,600 \\
\hline $5 a, 6 a, 7 a, 8 a$ & 19,900 & 8,690 & 25,500 & 496 & 9,460 & 64,000 \\
\hline $5 b, 6 b, 7 b, 8 b$ & 27,000 & 40,700 & 23,600 & 496 & 9,290 & 101,000 \\
\hline $9 \mathrm{a}$ & 19,900 & 8,690 & 25,500 & 496 & 9,190 & 63,800 \\
\hline $9 b$ & 27,000 & 50,300 & 25,500 & 496 & 9,290 & 113,000 \\
\hline $10 \mathrm{a}, 11 \mathrm{a}, 12 \mathrm{a}, 13 \mathrm{a}$ & 19,900 & 8,690 & 25,500 & 496 & 9,190 & 63,800 \\
\hline $10 b, 11 b, 12 b, 13 b$ & 27,000 & 50,300 & 25,500 & 496 & 9,290 & 113,000 \\
\hline $14 a$ & 19,900 & 8,690 & 25,500 & 496 & 9,190 & 63,800 \\
\hline $14 \mathrm{~b}$ & 27,000 & 50,300 & 25,500 & 496 & 9,290 & 113,000 \\
\hline $15 \mathrm{a}$ & 19,900 & 8,690 & 25,500 & 496 & 9,190 & 63,800 \\
\hline $15 b$ & 27,000 & 34,800 & 21,300 & 496 & 9,290 & 92,900 \\
\hline \multicolumn{7}{|c|}{2001} \\
\hline 0 & 10,700 & 8,760 & 2,400 & 383 & 4,470 & 26,700 \\
\hline $14 a$ & 10,700 & 8,760 & 12,600 & 383 & 10,800 & 43,200 \\
\hline $14 \mathrm{~b}$ & 23,200 & 11,600 & 10,800 & 328 & 10,400 & 56,300 \\
\hline $15 \mathrm{a}$ & 10,700 & 8,760 & 12,600 & 383 & 10,800 & 43,200 \\
\hline $15 b$ & 22,200 & 11,100 & 10,400 & 315 & 10,400 & 54,400 \\
\hline
\end{tabular}

outflows, simulating water demands just after the dam raise is finished. Most deliveries in these scenarios were set to actual deliveries from the base case year, either 2001 or 2002, with one exception. CWS, which releases water from Hagg Lake to improve water quality in the lower Tualatin River, would immediately take delivery of its new allocation. The timing and amount of new releases for CWS was determined by meeting minimum flow targets in the Tualatin River at Farmington Bridge (RM 33.3). These new targets were set to $156 \mathrm{ft}^{3} / \mathrm{s}$ in July, $195 \mathrm{ft}^{3} / \mathrm{s}$ in August, and $234 \mathrm{ft}^{3} / \mathrm{s}$ from September through November 15 for all dam height increases. To meet these targets under the hydrologic conditions of 2002 , CWS would need 25,500 acre-ft of water to be released 
from Hagg Lake. This is less than the total amount of water allocated to CWS with the dam raise; when available, any extra water was kept in the lake. In 2001, CWS would have required 22,000 acre-ft of water to meet minimum flows targets at Farmington Bridge. In this drought year, no new water was available, scale-backs were necessary, and this amount of water was not released in any of the scenarios.

The second delivery level ("b" scenarios) had higher outflows, simulating maximum future water demands. In these scenarios, all current users were allocated deliveries up to their contract levels; at present, some users are not using all their allocated water. Additional stored water from the dam raise was then allocated. In some scenarios, new deliveries had to be scaled back according to the following procedure. On May 31, the volume of new water available was determined from lake level and volume-elevation curves. If the new storage was greater than the new allocations and instream rights, then all users received 100 percent of their new water. However, if the new storage was less than or equal to the instream rights, users did not get any new water, and cutbacks to old water were made, if necessary, in order to fulfill the instream rights. If the new storage was greater than the instream rights, but less than that required to meet new allocations and instream rights, then the instream rights were met first, by setting aside an appropriate amount of water for the rest of the year, and the remaining new storage was distributed to users on the basis of a fraction of what was left.
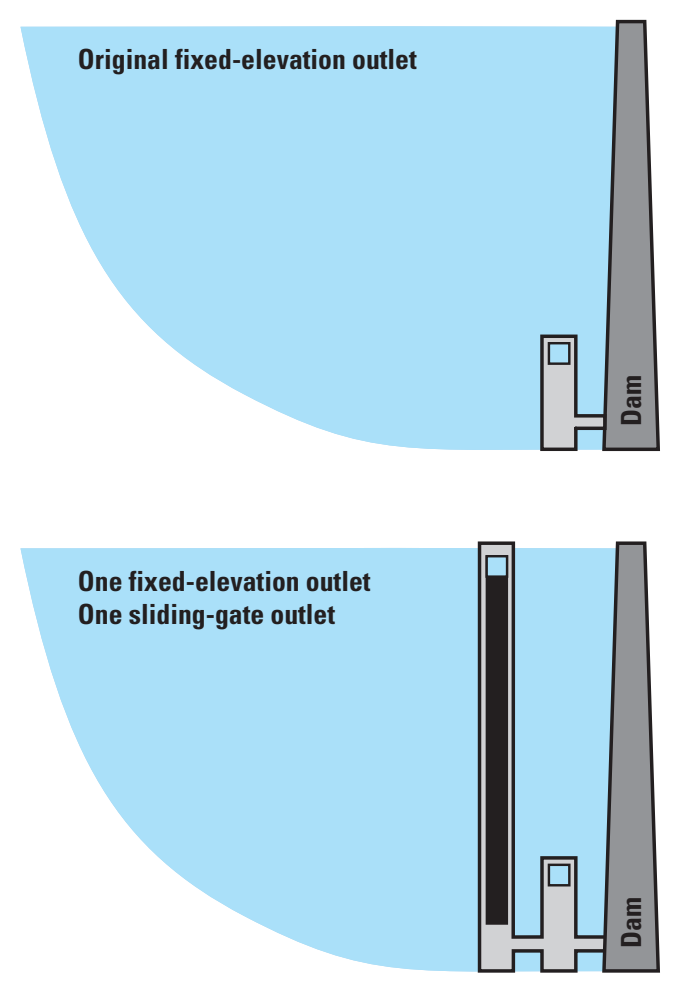

\section{Lake Outlets, Selective Withdrawal, and Downstream Temperature Targets}

The number and configuration of outlet structures and the operational rules for their use can have an important effect on the lake's water quality dynamics. Scenarios were run with several outlet configurations to examine this effect. Presently, the lake has one main outlet (plus a spillway), with an opening elevation between 69.8 and $72.5 \mathrm{~m}$ above sea level. Several model scenarios were run with this original fixedelevation outlet (table 1). In other scenarios, additional fixed or sliding-gate (variable-elevation) outlets were added and used in conjunction with the original outlet (fig. 2). In some cases, a sliding-gate outlet was used alone. The scenarios with more than one fixed-elevation outlet, or any scenario with a sliding-gate outlet, allowed water to be withdrawn from different elevations in the lake. In this way, water could be withdrawn from different depths and blended, if necessary, to attain an outflow with desired water quality characteristics. These scenarios are said to have "selective withdrawal" capability. Some dams have been retrofitted to add this capability in the form of multiple fixed gates, such as at Shasta Dam in northern California, or in the form of an assembly of multiple sliding gates, such as at Cougar Dam east of Eugene, Oregon; both of these retrofits were done to help attain downstream temperature targets.
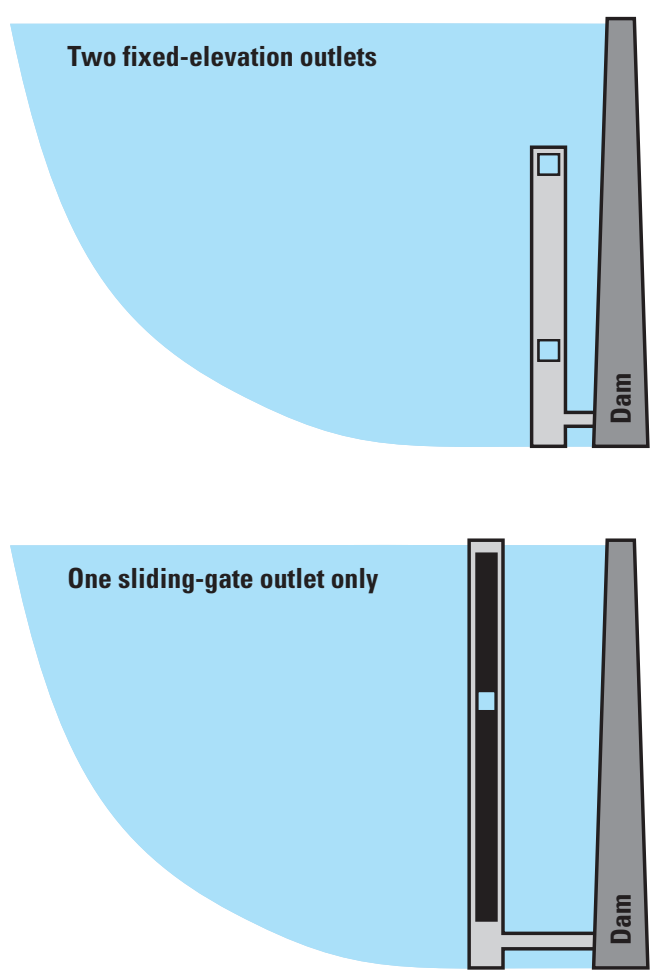

Figure 2. Types of outlet assemblies tested in the dam raise scenarios, Hagg Lake, Oregon. The second fixed-elevation outlet was positioned at the current full-pool elevation. Sliding-gate (adjustable-elevation) outlets were assumed to span an elevation range from the top of the reservoir to below the lake's existing outlet. 
Hagg Lake model scenarios with selective withdrawal capability were run in an attempt to meet a downstream water temperature target. The target temperature used in this study was created to (1) provide a more-natural seasonal temperature pattern for Scoggins Creek downstream of the dam, and (2) comply with Oregon's temperature standard. One could simply use the temperature standard as a target, but that leaves no room for warming in downstream reaches, and does not match conditions upstream of the reservoir. In this study, the temperature target was the 30-day running average of the 30-day running average of the 7-day running average of the measured daily maximum water temperature in Scoggins Creek upstream of Hagg Lake for 2002. Water temperature standards in Oregon are based on the 7-day running average of the daily maximum (7dADM); the two 30-day running averages were used to smooth and eliminate the influence of shorter timescale variations due to weather patterns. In this way, the target has a close similarity to upstream conditions. The State maximum water temperature standard in Scoggins Creek downstream of Hagg Lake is $13^{\circ} \mathrm{C}$ from October 15 to May 15 , and $18^{\circ} \mathrm{C}$ for the rest of the year (Oregon Department of Environmental Quality, 2003). The target temperature meets these criteria throughout the year (fig. 3). Other temperature targets could easily be created and tested, but this one provided a link between upstream and downstream conditions.

The 7dADM water temperature downstream of the dam in 2002, as in most years, did not comply with Oregon's temperature standard for Scoggins Creek (fig. 3). It is not known whether additional lake outlets and selective withdrawal might be required as part of a dam raise; these model scenarios were included simply to explore the consequences of including selective withdrawal as a means of complying with the temperature criteria in Scoggins

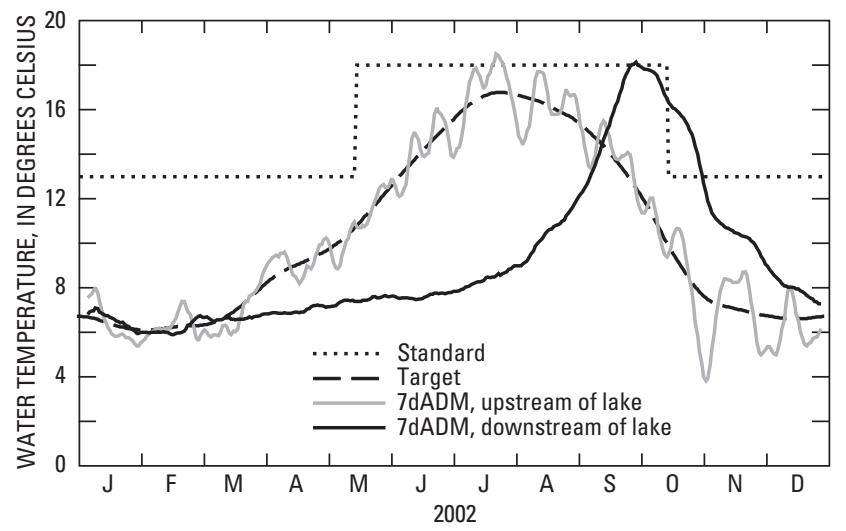

Figure 3. Oregon's maximum water temperature standard in Scoggins Creek downstream of the dam, the smoothed temperature target used in model scenarios, the 7-day moving average of the daily maximum temperature (7dADM) in Scoggins Creek upstream of the lake, and the measured temperature (7dADM) in 2002 downstream of Scoggins Dam.
Creek. The use of these scenarios is not meant to imply that temperature regulations would require selective withdrawal, only that this is one means of addressing the downstream temperature issues.

Version 3.12 of CE-QUAL-W2 does not contain algorithms that allow the dynamic blending of withdrawals from multiple outlets to meet a target release water temperature. Nor does it have algorithms to automatically select the optimum depth for a sliding-gate outlet. In some past applications of CE-QUAL-W2, these necessary operational and blending decisions were made outside of the model and optimized in an iterative manner (Hanna and others, 1999; Bartholow and others, 2001), a process that required many model runs. For this work, a new subroutine was written for CE-QUAL-W2 that internalized these procedures, allowing blending rates and sliding-gate positions to be set during the model run; in this way, iteration with many model runs was avoided. Details of this new subroutine are described in Appendix A of this report. When selective withdrawal and blending was used, the primary goal was to meet the downstream temperature targets, using operational rules that are detailed in Appendix A. The operational rules tested in these scenarios are but one of many potential sets of rules and may not be an optimal design. They are sufficient for use in these scenarios, however, as a demonstration and proof of concept.

\section{Results}

\section{Water Surface Elevation}

Managed according to the fill curve, Hagg Lake water surface levels generally rise in the winter as rainfall accumulates and demand for water is low (fig. 4). The water surface elevation typically reaches a maximum in late May and declines through the summer and autumn as downstream users call for water releases. The lake reached a minimum water surface elevation in these model scenarios between midNovember and mid-December.

The year 2002 base case, scenario 0, was simulated using the lake's original fill curve. Scenarios 1 through 4 used the new fill curve for the $6.1 \mathrm{~m}(20 \mathrm{ft})$ dam raise. For these scenarios, inflows were sufficient to meet that target maximum elevation. Scenarios 5 through 8 used the new fill curve for the $12.2 \mathrm{~m} \mathrm{(40} \mathrm{ft)} \mathrm{dam} \mathrm{raise,} \mathrm{but} \mathrm{natural} \mathrm{inflows} \mathrm{were} \mathrm{insufficient}$ in 2002 to reach the target maximum elevation; the maximum elevation was $2.8 \mathrm{~m}$ lower than the target in late May; this unfilled storage corresponds to about 11.5 percent of the total potential storage. With extra inflow from the Sain Creek tunnel, scenarios 9 through 13 started the summer season with a full lake using the $12.2 \mathrm{~m}(40 \mathrm{ft})$ dam raise. 

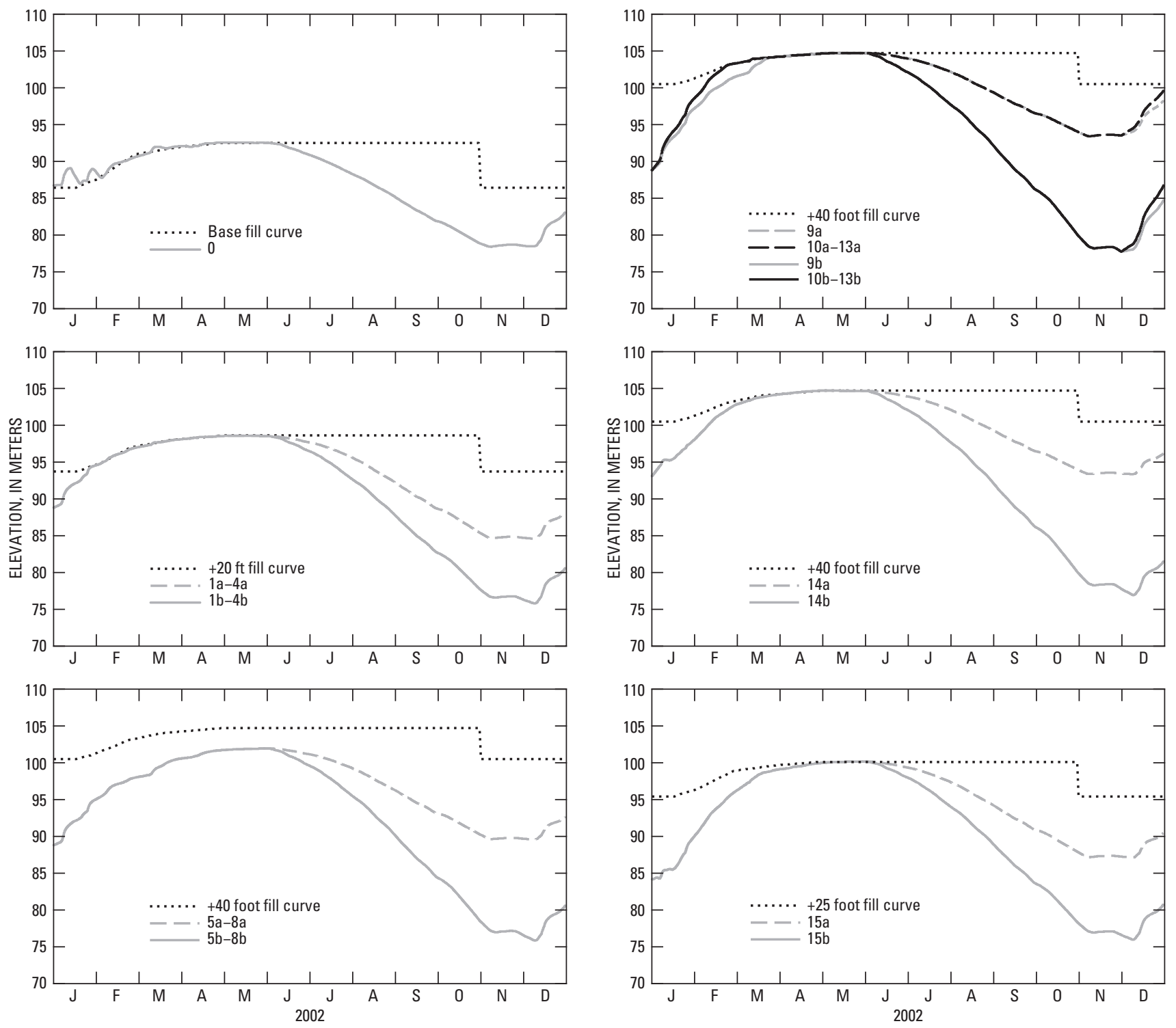

Figure 4. Water surface elevations for the scenarios with the relevant fill curves, Hagg Lake, Oregon, 2002. Scenario details are listed in table 1.

Scenarios $14[12.2 \mathrm{~m}(40 \mathrm{ft})$ raise $]$ and $15[7.6 \mathrm{~m}(25 \mathrm{ft})$ raise] in 2002 also started the summer with a full lake, due to augmented inflows via pump-back. The year 2001 base case, scenario 0 , simulated with the lake's original fill curve, did not fill the lake due to drought conditions (fig. 5). Even with pump-back in scenarios 14 and 15 for 2001, the lake did not reach the new fill curve for the $12.2 \mathrm{~m}(40 \mathrm{ft})$ or $7.6 \mathrm{~m}(25 \mathrm{ft})$ dam raises because available water for pumping was limited, again due to the drought.

Water surface elevations resulting from the two Sain Creek tunnel inflow scenarios, 9 (low inflow rate) and 10 (high inflow rate), were similar despite the difference in inflows. Both levels of inflow augmentation were sufficient to fill the lake, and excess water was simply spilled from the lake. These simulations were based on 2002, a normal hydrologic year; it is possible that the higher inflows would be necessary to fill the lake in a year with lower than normal inflows.

Water surface elevations for scenarios with initial water demands just after construction ("a") and maximum water demands ("b") generally were identical from January through the end of May (figs. $4, \underline{5}$ ), as releases during this time were mostly for instream flow requirements and spills to keep the water surface elevation on the fill curve. Once summer water deliveries began, the water surface elevations for the " $a$ " and "b" scenarios diverged. Note that the future maximum water demands caused the lake stage to be very low in November, thus making it more difficult to fill the lake for the next year without augmented inflows via a Sain Creek tunnel or from pump-back. 

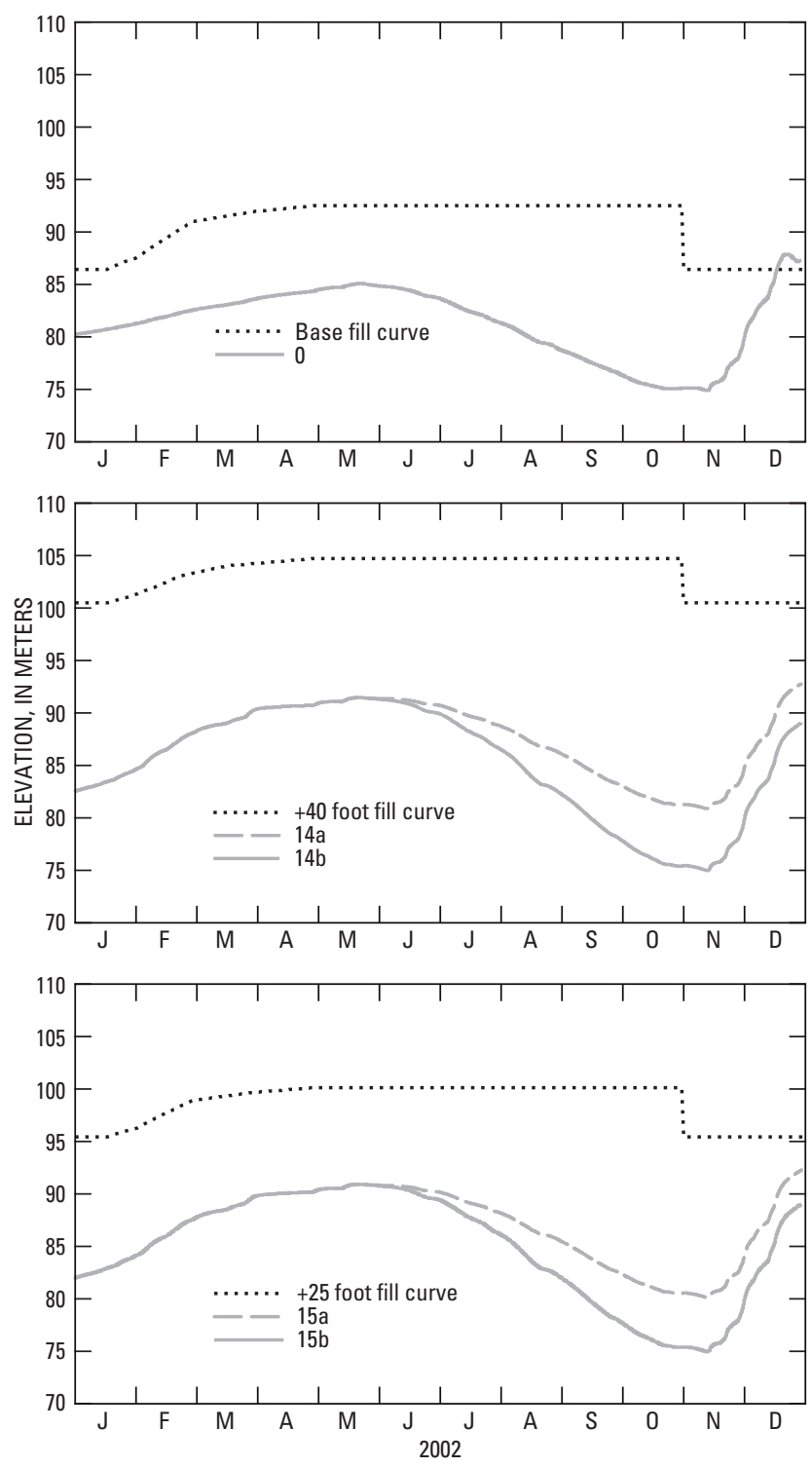

Figure 5. Water surface elevations for the scenarios with the relevant fill curves, Hagg Lake, Oregon, 2001. Scenario details are listed in table 1.

\section{Water Temperature}

\section{Lake}

Changes in the water temperature regime can fundamentally alter a lake's water quality. For instance, chemical reactions and algal growth rates are temperature dependent. The distribution of fish in a lake can change, as water temperature is an important habitat factor (Ferguson, 1958; Cherry and others, 1977). The duration and depth of temperature stratification also can affect the time and volume of water that is isolated during the summer, affecting anoxia and ammonia production and accumulation in the lake's hypolimnion.

In the 2002 base case, the annual average lake temperature was $10.9^{\circ} \mathrm{C}$ (table 3). All 2002 dam-raise scenarios produced cooler annual average temperatures, ranging from 8.7 to $10.7^{\circ} \mathrm{C}$. Scenarios with selective withdrawal, which allowed some of the warmer water near the top of the lake to be discharged downstream, were cooler [9. $4^{\circ} \mathrm{C}$, standard deviation (SD) $\left.0.3^{\circ} \mathrm{C}\right]$, than those with only the original fixed-elevation outlet $\left(10.3^{\circ} \mathrm{C}, \mathrm{SD} 0.2^{\circ} \mathrm{C}\right)$. The maximum lake surface water temperature (averaged over the top $2 \mathrm{~m}$ ) in the base case was $26.6^{\circ} \mathrm{C}$. In the 2002 dam-raise scenarios, the peak surface water temperature ranged between 25.3 and $26.7^{\circ} \mathrm{C}$.

Hagg Lake undergoes an annual cycle of thermal stratification. In this study, a thermocline was defined to be present when a temperature change of at least $1{ }^{\circ} \mathrm{C}$ over $1 \mathrm{~m}$ depth was continuously present. The depth of the thermocline was defined as the depth with the greatest temperature gradient when a thermocline was present. Scenarios for 2002 using selective withdrawal had a shallower thermocline $(7.1 \mathrm{~m}, \mathrm{SD} 0.6 \mathrm{~m})$ than those with only one fixed-elevation outlet (9.6 m, SD 0.9 m) (figs. 6, 7 and table 3). Selective withdrawal exported warm water from near the surface of the lake, limiting epilimnion development; scenarios with one fixed outlet at a mid-to-lower elevation in the lake stored more summer heat at the lake surface and allowed the epilimnion to develop undisturbed.

The thermocline depth deepened through the summer into autumn for those 2002 scenarios with only one fixed-elevation outlet (scenario 10b in fig. 6). In all scenarios, the elevation of the lowest lake outlet appeared to provide a lower limit for the thermocline depth. This result also was found in modeling by Casamitjana and others (2003) for reservoirs where summer inflow rates were small compared to withdrawals.

Scenarios for 2002 with the $12.2 \mathrm{~m}(40 \mathrm{ft})$ raise and extra inflow from the upper Tualatin River via the Sain Creek tunnel (10-13) and from pump-back (14) resulted in lower annual average water temperatures compared to their counterpart scenarios without extra inflow (scenarios 5-8 for the former and 6 for the latter). The difference averaged about $-0.5^{\circ} \mathrm{C}$ for the Sain Creek tunnel and $-0.4^{\circ} \mathrm{C}$ with pump-back. All scenarios with extra inflows also had shorter durations of thermal stratification and shallower thermoclines.

The 2001 scenarios (14 and 15) that combined the effects of selective withdrawal and pump-back resulted in cooler annual average temperatures compared to the base case; the difference averaged $-0.8^{\circ} \mathrm{C}$. These scenarios also produced longer periods of thermal stratification and a shallower thermocline relative to the 2001 base case. 
Table 3. Whole-lake annual scenario results for water temperature and dissolved oxygen, Hagg Lake, Oregon.

[Abbreviations: ${ }^{\circ} \mathrm{C}$, degrees Celsius; m, meter; mg/L, milligram per liter. Symbols: <, less than]

\begin{tabular}{|c|c|c|c|c|c|c|c|c|c|}
\hline \multicolumn{2}{|c|}{ Scenario } & $\begin{array}{c}\text { Water } \\
\text { temperature, } \\
\text { mean } \\
\left({ }^{\circ} \mathrm{C}\right)\end{array}$ & $\begin{array}{c}\text { Water } \\
\text { temperature, } \\
\text { maximum } \\
\text { surface } \\
\text { (top } 2 \mathrm{~m}) \\
\left({ }^{\circ} \mathrm{C}\right)\end{array}$ & $\begin{array}{l}\text { Thermocline } \\
\text { duration } \\
\text { (days) }\end{array}$ & $\begin{array}{l}\text { Thermocline } \\
\text { depth, mean } \\
\text { (m) }\end{array}$ & $\begin{array}{c}\text { Dissolved } \\
\text { oxygen, mean } \\
\text { (mg/L) }\end{array}$ & $\begin{array}{l}\text { Volume with } \\
<1 \mathrm{mg} / \mathrm{L} \\
\text { dissolved } \\
\text { oxygen } \\
\text { (percentage) }\end{array}$ & $\begin{array}{c}\text { Continuous } \\
\text { presence of low } \\
\text { (<1 mg/L) } \\
\text { dissolved oxygen } \\
\text { (days) }\end{array}$ & $\begin{array}{c}\text { Turnover } \\
\text { (day of year) }\end{array}$ \\
\hline \multicolumn{10}{|c|}{2002} \\
\hline 0 & Base & 10.9 & 26.6 & 180.0 & 10.1 & 9.52 & 1.26 & 64.2 & 329.2 \\
\hline \multirow{2}{*}{1} & $\mathrm{a}$ & 10.7 & 26.4 & 190.6 & 10.8 & 9.51 & 0.57 & 53.2 & 341.0 \\
\hline & $\mathrm{b}$ & 10.5 & 26.7 & 178.6 & 10.2 & 9.77 & 0.64 & 52.6 & 325.8 \\
\hline \multirow{2}{*}{2} & $\mathrm{a}$ & 9.8 & 25.9 & 188.0 & 7.2 & 9.59 & 0.18 & 18.8 & 338.2 \\
\hline & $\mathrm{b}$ & 9.5 & 25.8 & 189.6 & 6.9 & 9.90 & 0.07 & 26.0 & 325.4 \\
\hline \multirow{2}{*}{3} & $\mathrm{a}$ & 9.8 & 25.9 & 193.6 & 7.9 & 9.54 & 0.30 & 29.8 & 340.2 \\
\hline & $\mathrm{b}$ & 9.7 & 25.8 & 192.2 & 7.9 & 9.83 & 0.35 & 34.2 & 329.2 \\
\hline \multirow{2}{*}{4} & $\mathrm{a}$ & 9.8 & 26.1 & 192.4 & 7.8 & 9.46 & 0.11 & 11.6 & 340.2 \\
\hline & $\mathrm{b}$ & 9.5 & 26.4 & 192.8 & 7.4 & 9.77 & 0.05 & 28.0 & 331.0 \\
\hline \multirow{2}{*}{5} & $\mathrm{a}$ & 10.5 & 26.4 & 201.4 & 10.0 & 9.45 & 0.39 & 48.4 & 345.0 \\
\hline & $\mathrm{b}$ & 10.4 & 26.6 & 192.2 & 10.0 & 9.80 & 0.44 & 48.4 & 329.2 \\
\hline \multirow{2}{*}{6} & a & 9.7 & 26.0 & 188.0 & 7.1 & 9.52 & 0.00 & 7.6 & 340.6 \\
\hline & $\mathrm{b}$ & 9.4 & 25.3 & 192.4 & 6.9 & 9.95 & 0.04 & 19.2 & 329.2 \\
\hline \multirow{2}{*}{7} & a & 9.7 & 26.3 & 188.0 & 7.4 & 9.41 & 0.00 & 0.2 & 341.6 \\
\hline & $\mathrm{b}$ & 9.6 & 26.1 & 192.4 & 7.6 & 9.81 & 0.18 & 31.2 & 330.4 \\
\hline \multirow{2}{*}{8} & $\mathrm{a}$ & 9.6 & 26.2 & 192.4 & 7.7 & 9.39 & 0.00 & 0.0 & 343.4 \\
\hline & $\mathrm{b}$ & 9.3 & 26.2 & 190.8 & 6.8 & 9.83 & 0.03 & 20.8 & 331.0 \\
\hline \multirow{2}{*}{9} & $\mathrm{a}$ & 10.2 & 26.4 & 176.2 & 8.2 & 9.66 & 0.21 & 33.4 & 354.6 \\
\hline & $\mathrm{b}$ & 10.1 & 26.6 & 190.0 & 9.7 & 10.02 & 0.23 & 50.6 & 329.0 \\
\hline \multirow{2}{*}{10} & $\mathrm{a}$ & 10.2 & 26.4 & 176.2 & 8.2 & 9.75 & 0.18 & 31.6 & 352.4 \\
\hline & $\mathrm{b}$ & 10.0 & 26.6 & 190.0 & 9.7 & 10.11 & 0.22 & 50.2 & 329.0 \\
\hline \multirow{2}{*}{11} & $\mathrm{a}$ & 9.2 & 25.8 & 176.6 & 6.5 & 9.87 & 0.00 & 0.0 & 348.8 \\
\hline & $\mathrm{b}$ & 8.9 & 25.4 & 187.8 & 6.2 & 10.31 & 0.03 & 20.8 & 331.2 \\
\hline \multirow{2}{*}{12} & a & 9.4 & 26.4 & 183.2 & 7.4 & 9.66 & 0.00 & 0.0 & 350.0 \\
\hline & $\mathrm{b}$ & 9.1 & 26.3 & 192.2 & 7.3 & 10.11 & 0.12 & 26.0 & 334.0 \\
\hline \multirow{2}{*}{13} & a & 9.1 & 26.2 & 192.2 & 7.4 & 9.71 & 0.00 & 0.0 & 349.8 \\
\hline & $\mathrm{b}$ & 8.7 & 25.9 & 188.0 & 6.3 & 10.19 & 0.01 & 12.8 & 333.2 \\
\hline \multirow{2}{*}{14} & $\mathrm{a}$ & 9.3 & 26.2 & 184.2 & 6.6 & 9.50 & 0.00 & 0.0 & 341.6 \\
\hline & $\mathrm{b}$ & 9.0 & 25.6 & 188.0 & 6.1 & 10.00 & 0.02 & 11.4 & 329.4 \\
\hline \multirow{2}{*}{15} & $\mathrm{a}$ & 9.0 & 26.1 & 185.4 & 7.0 & 9.52 & 0.25 & 29.4 & 339.6 \\
\hline & $\mathrm{b}$ & 9.6 & 25.4 & 192.2 & 7.0 & 9.91 & 0.09 & 31.8 & 325.2 \\
\hline \multicolumn{10}{|c|}{2001} \\
\hline 0 & Base & 11.0 & 25.7 & 188.8 & 8.0 & 9.15 & 2.55 & 85.4 & 317.1 \\
\hline \multirow{2}{*}{14} & $\mathrm{a}$ & 10.3 & 25.6 & 201.0 & 7.6 & 9.32 & 1.00 & 52.2 & 332.6 \\
\hline & $\mathrm{b}$ & 10.0 & 25.6 & 191.0 & 6.8 & 9.64 & 0.58 & 51.8 & 322.8 \\
\hline \multirow{2}{*}{15} & $\mathrm{a}$ & 10.3 & 25.6 & 200.2 & 7.7 & 9.34 & 1.00 & 54.0 & 332.2 \\
\hline & $\mathrm{b}$ & 10.1 & 25.4 & 191.0 & 6.9 & 9.63 & 0.61 & 53.2 & 322.8 \\
\hline
\end{tabular}



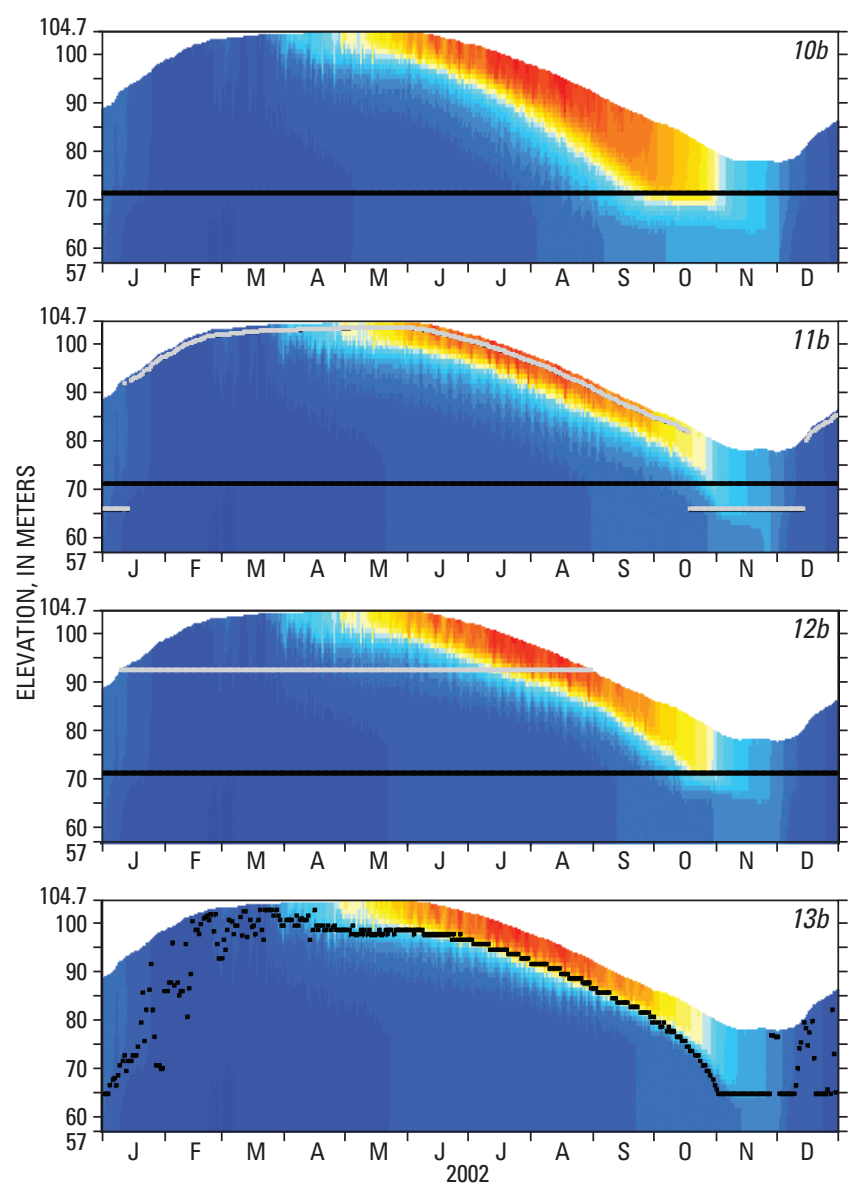

TEMPERATURE, IN DEGREES CELSIUS

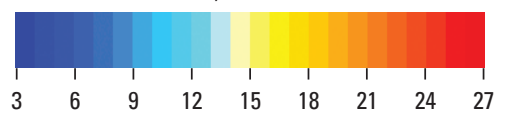

Figure 6. Simulated water temperature in the deepest part of the lake near the dam for 2002 scenarios 10b, 11b, 12b, and 13b, Hagg Lake, Oregon. The centerline elevations of the lake outlets are shown by the grey and black lines. Scenario 10b has one fixed-elevation outlet. Scenario 11b has one fixed- and one variable-elevation outlet. Scenario 12b has two fixedelevation outlets. Scenario 13b has one variable-elevation outlet. Refer to table 1 for more details on the scenarios.

All "a" scenarios, which resulted in a deeper lake in October-December than the "b" scenarios, had a later turnover date than their "b" counterparts, by an average of 15 days in 2002 and 9 days in 2001. Given the model's high degree of accuracy in simulating lake circulation and heat-exchange processes, the model's predictions of the turnover date also should be accurate. The turnover date, of course, is influenced greatly by meteorological conditions, so variations in the weather can easily push the turnover date to earlier or later dates.
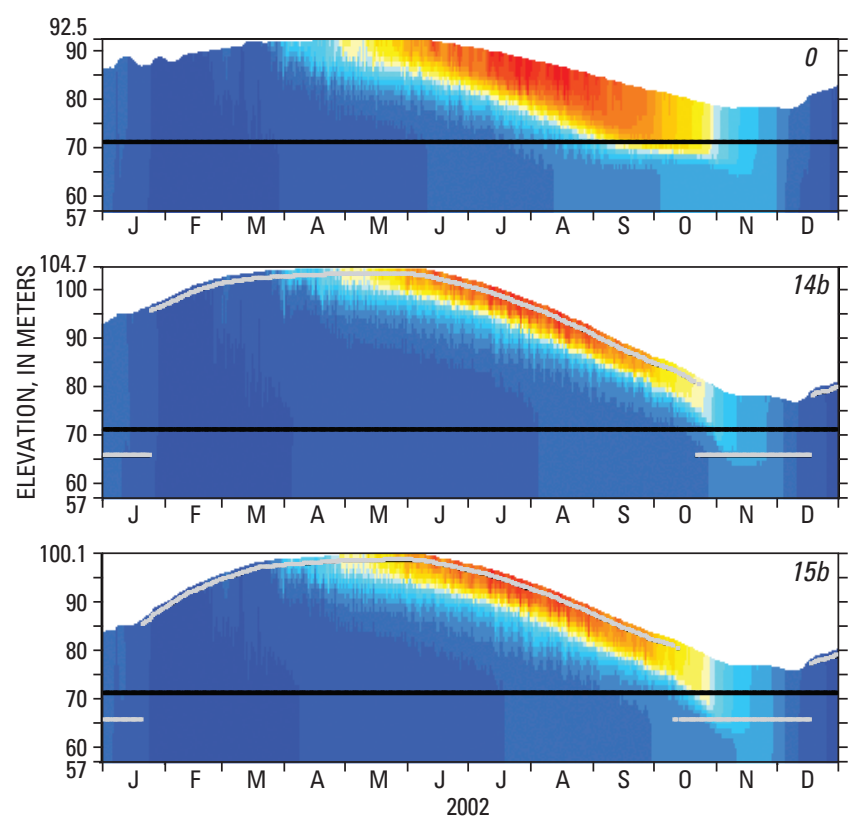

TEMPERATURE, IN DEGREES CELSIUS

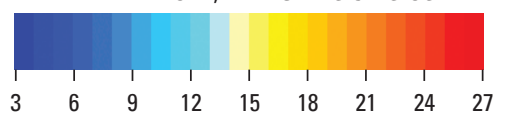

Figure 7. Simulated water temperature in the deepest part of the lake near the dam for 2002 base case (0) and pump-back scenarios (14b, 15b), Hagg Lake, Oregon.

The centerline elevations of the lake outlets are shown by the grey and black lines. Scenario 0 has a fixed-elevation outlet, while $14 \mathrm{~b}$ and $15 \mathrm{~b}$ have both a fixed-elevation and a variable-elevation outlet. Scenario details are listed in table 1.

\section{Outflow}

Water temperatures in Scoggins Creek downstream of the dam are heavily influenced by the presence of Hagg Lake. The temperature maximum in Scoggins Creek upstream of the reservoir, for example, typically occurs in late July (fig. 3). Downstream of the dam, the peak temperature in Scoggins Creek usually occurs in late September. This shift in the peak temperature occurs because Hagg Lake releases relatively cold water from near the bottom of the lake in spring and summer, then releases stored summer heat in autumn as the lake is drawn down. Keeping a more natural seasonal temperature pattern downstream of a dam is often desirable for aquatic biota (fish). Some dams have been designed or retrofitted with selective withdrawal towers, which allow discharge waters to be blended from different lake elevations with different temperatures to match a more natural seasonal temperature pattern. As described previously, selective withdrawal capability was modeled for Hagg Lake in some scenarios. 
Scenarios using only the original, fixed-elevation outlet (scenarios $0,1,5,9,10$ ), did not have selective withdrawal capability. For these runs, the simulated outflow temperature was cooler than the target temperature through August (or September), and warmer than the target for most of the rest of the year (fig. 8). During a short part of the year, outflow temperatures from some of these scenarios exceeded the maximum water temperature criteria for Scoggins Creek (fig. 8). The scenarios with larger withdrawals, the "b" scenarios using maximum water demands, had greater exceedances of the temperature criteria than those that kept more water in the lake through the year. These exceedances can be quantified in terms of "degree days" (Bartholow and others, 2001) (table 4), where 1 degree day represents $1^{\circ} \mathrm{C}$ above the standard for a period of one day. Note that these comparisons do not use the 7dADM water temperature; this analysis was not meant to be a critical analysis of compliance or violation of the temperature standard, but a simple indication of a scenario's ability to keep the downstream temperatures less than the relevant temperature criterion.

Scenarios with selective withdrawal capability were run in an attempt to meet the downstream temperature target. Scenarios 2, 6, 11, 14, and 15, which used both the original fixed outlet and one sliding-gate (variable-elevation) outlet, were best able to match the target outflow temperatures (figs. 8, 9). Late in the year, however, the water left in the reservoir was not cold enough to reach the target; the lake "ran out" of cold water. None of the 2002 outflows from these scenarios violated the downstream temperature criteria (figs. 8, 9; table 4). Scenarios 3, 7 and 12, simulating two fixed-elevation outlets, allowed blending of water from two different depths until the lake's stage declined below the top outlet, thus ending selective withdrawal capability. Outflow water temperatures exceeded the criteria to some extent in all these scenarios (fig. 8; table 4). Scenarios 4, 8 and 13 simulated only one outlet, but it was a sliding-gate (variableelevation) outlet. These scenarios matched the general seasonal pattern of the target temperature (as in scenarios $2,6,11,14,15)$, but because only one elevation adjustment per day was allowed and because the outlet was usually positioned in the middle of the thermocline, the temperature of the outflow varied greatly both above and below the target temperature. This variability led to occasional exceedances of the downstream water temperature criteria in the summer (fig. 8; table 4).

On an annual average basis, outflows from 2002 scenarios with selective withdrawal were warmer $\left(11.6^{\circ} \mathrm{C}, \mathrm{SD}\right.$ $0.8^{\circ} \mathrm{C}$ ) than those using just the original fixed-elevation outlet $\left(8.9^{\circ} \mathrm{C}, \mathrm{SD} 1.2^{\circ} \mathrm{C}\right)$. The effort to match a more natural seasonal temperature pattern in the outflow causes a large amount of heat to be exported from the lake's epilimnion during the summer. The scenarios that were best able to match the downstream temperature targets were those that could access both warm water near the lake surface and colder water in the deeper part of the lake.
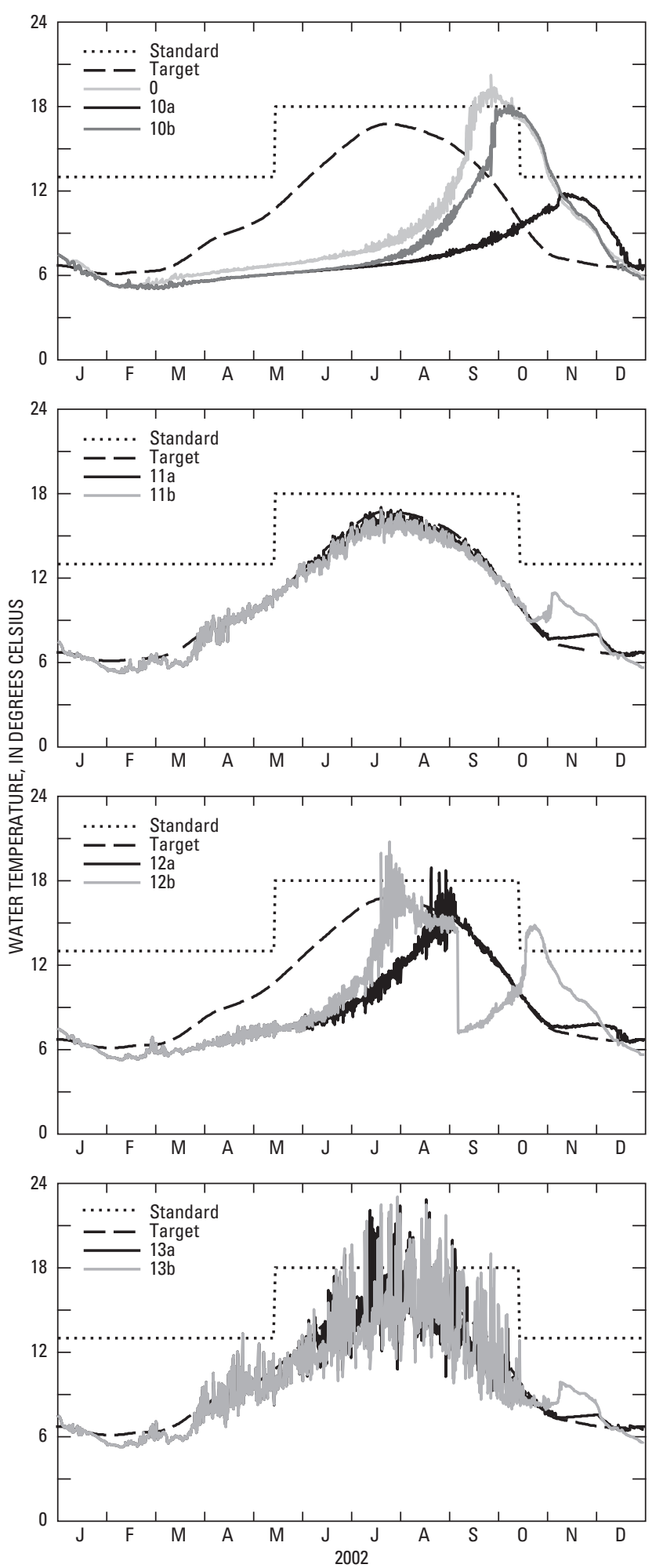

Figure 8. Simulated water temperature in the outflow for scenarios 0, 10, 11, 12, and 13, Hagg Lake, Oregon, 2002. The relevant water temperature standard and the target temperature are shown. Scenario details are listed in table 1. 
Table 4. Annual scenario results for the outflow from Hagg Lake, Oregon.

[Abbreviations: ${ }^{\circ} \mathrm{C}$, degrees Celsius; mg/L, milligram per liter; $\mu \mathrm{g} / \mathrm{L}$, microgram per liter; $\mathrm{N}$, nitrogen; $\mathrm{P}$, phosphorus]

\begin{tabular}{|c|c|c|c|c|c|c|c|c|}
\hline \multicolumn{2}{|c|}{ Scenario } & $\begin{array}{c}\text { Water } \\
\text { temperature, } \\
\text { mean } \\
\left({ }^{\circ} \mathrm{C}\right)\end{array}$ & $\begin{array}{c}\text { Above } \\
\text { temperature } \\
\text { standard } \\
\text { (degree days) }\end{array}$ & $\begin{array}{c}\text { Dissolved } \\
\text { oxygen, } \\
\text { mean } \\
(\mathrm{mg} / \mathrm{L})\end{array}$ & $\begin{array}{l}\text { Dissolved } \\
\text { oxygen, } \\
\text { minimum } \\
\text { (mg/L) }\end{array}$ & $\begin{array}{c}\text { Ammonia, } \\
\text { mean } \\
(\mu \mathrm{g} / \mathrm{L} \text { as } N)\end{array}$ & $\begin{array}{c}\text { Orthophosphate, } \\
\text { mean } \\
(\mu \mathrm{g} / \mathrm{L} \text { as } \mathrm{P})\end{array}$ & $\begin{array}{c}\text { Chlorophyll } a, \\
\text { mean } \\
(\mu \mathrm{g} / \mathrm{L})\end{array}$ \\
\hline \multicolumn{9}{|c|}{2002} \\
\hline 0 & Base & 9.1 & 60.5 & 8.76 & 4.2 & 10.7 & 6.27 & 0.64 \\
\hline \multirow{2}{*}{1} & a & 8.5 & 48.2 & 7.88 & 3.8 & 10.0 & 6.94 & 0.32 \\
\hline & $\mathrm{b}$ & 10.0 & 67.1 & 8.01 & 4.7 & 11.5 & 6.47 & 0.49 \\
\hline \multirow{2}{*}{2} & $\mathrm{a}$ & 11.6 & 0.0 & 7.99 & 0.7 & 11.5 & 5.67 & 0.89 \\
\hline & $\mathrm{b}$ & 12.1 & 0.0 & 8.22 & 2.6 & 11.8 & 5.36 & 0.79 \\
\hline \multirow{2}{*}{3} & $\mathrm{a}$ & 11.0 & 0.6 & 8.21 & 3.4 & 11.2 & 5.50 & 0.98 \\
\hline & $\mathrm{b}$ & 11.4 & 40.1 & 8.44 & 4.9 & 11.4 & 5.53 & 0.79 \\
\hline \multirow{2}{*}{4} & $\mathrm{a}$ & 10.9 & 11.4 & 8.26 & 0.8 & 10.8 & 5.31 & 0.83 \\
\hline & $\mathrm{b}$ & 11.3 & 16.4 & 8.37 & 2.3 & 11.1 & 4.96 & 0.89 \\
\hline \multirow{2}{*}{5} & $\mathrm{a}$ & 8.1 & 0.1 & 7.11 & 3.7 & 9.4 & 7.23 & 0.18 \\
\hline & $\mathrm{b}$ & 10.4 & 63.4 & 7.59 & 4.8 & 11.6 & 6.50 & 0.46 \\
\hline \multirow{2}{*}{6} & a & 12.7 & 0.0 & 7.36 & 1.6 & 12.0 & 5.77 & 0.83 \\
\hline & $\mathrm{b}$ & 13.0 & 0.0 & 7.80 & 3.2 & 12.0 & 5.58 & 0.44 \\
\hline \multirow{2}{*}{7} & $\mathrm{a}$ & 12.1 & 2.8 & 7.77 & 2.3 & 11.9 & 5.24 & 0.86 \\
\hline & $\mathrm{b}$ & 12.1 & 38.0 & 8.11 & 4.8 & 11.8 & 5.16 & 0.86 \\
\hline \multirow{2}{*}{8} & $\mathrm{a}$ & 11.9 & 12.0 & 7.85 & 1.9 & 11.4 & 5.12 & 0.67 \\
\hline & $\mathrm{b}$ & 12.4 & 23.8 & 8.09 & 3.1 & 11.4 & 4.63 & 0.87 \\
\hline \multirow{2}{*}{9} & a & 7.7 & 0.0 & 7.74 & 5.2 & 9.5 & 7.46 & 0.14 \\
\hline & $\mathrm{b}$ & 10.0 & 55.8 & 8.07 & 5.3 & 11.2 & 6.85 & 0.38 \\
\hline \multirow{2}{*}{10} & $\mathrm{a}$ & 7.2 & 0.0 & 8.48 & 5.2 & 9.3 & 7.24 & 0.17 \\
\hline & $\mathrm{b}$ & 9.4 & 55.8 & 8.54 & 5.3 & 10.9 & 6.76 & 0.37 \\
\hline \multirow{2}{*}{11} & $\mathrm{a}$ & 11.2 & 0.0 & 8.71 & 2.5 & 11.5 & 5.93 & 0.85 \\
\hline & $\mathrm{b}$ & 11.9 & 0.0 & 8.79 & 4.8 & 11.8 & 5.69 & 0.50 \\
\hline \multirow{2}{*}{12} & $\mathrm{a}$ & 9.8 & 0.5 & 9.02 & 3.0 & 11.0 & 5.85 & 0.72 \\
\hline & $\mathrm{b}$ & 10.7 & 18.3 & 8.98 & 5.8 & 11.5 & 5.52 & 0.84 \\
\hline \multirow{2}{*}{13} & $\mathrm{a}$ & 10.8 & 20.7 & 9.27 & 3.3 & 10.9 & 5.28 & 0.86 \\
\hline & $\mathrm{b}$ & 11.6 & 22.7 & 9.29 & 4.5 & 10.9 & 4.43 & 1.14 \\
\hline \multirow{2}{*}{14} & $\mathrm{a}$ & 11.4 & 0.0 & 8.33 & 2.4 & 13.2 & 10.20 & 1.02 \\
\hline & $\mathrm{b}$ & 12.0 & 0.0 & 8.32 & 3.5 & 13.3 & 9.45 & 0.75 \\
\hline \multirow{2}{*}{15} & $\mathrm{a}$ & 11.6 & 0.0 & 7.96 & 0.8 & 12.4 & 7.29 & 1.08 \\
\hline & $\mathrm{b}$ & 12.2 & 0.0 & 8.16 & 2.9 & 12.6 & 7.06 & 0.70 \\
\hline \multicolumn{9}{|c|}{2001} \\
\hline 0 & Base & 11.8 & 111.3 & 7.85 & 5.1 & 12.4 & 5.06 & 0.82 \\
\hline \multirow{2}{*}{14} & $\mathrm{a}$ & 12.6 & 0.0 & 7.03 & 0.2 & 13.6 & 6.06 & 0.44 \\
\hline & $\mathrm{b}$ & 13.2 & 0.3 & 7.43 & 1.1 & 12.6 & 5.36 & 0.51 \\
\hline \multirow{2}{*}{15} & $\mathrm{a}$ & 12.7 & 0.0 & 7.02 & 0.3 & 13.9 & 6.04 & 0.46 \\
\hline & b & 13.2 & 0.5 & 7.43 & 1.1 & 12.6 & 5.35 & 0.53 \\
\hline
\end{tabular}



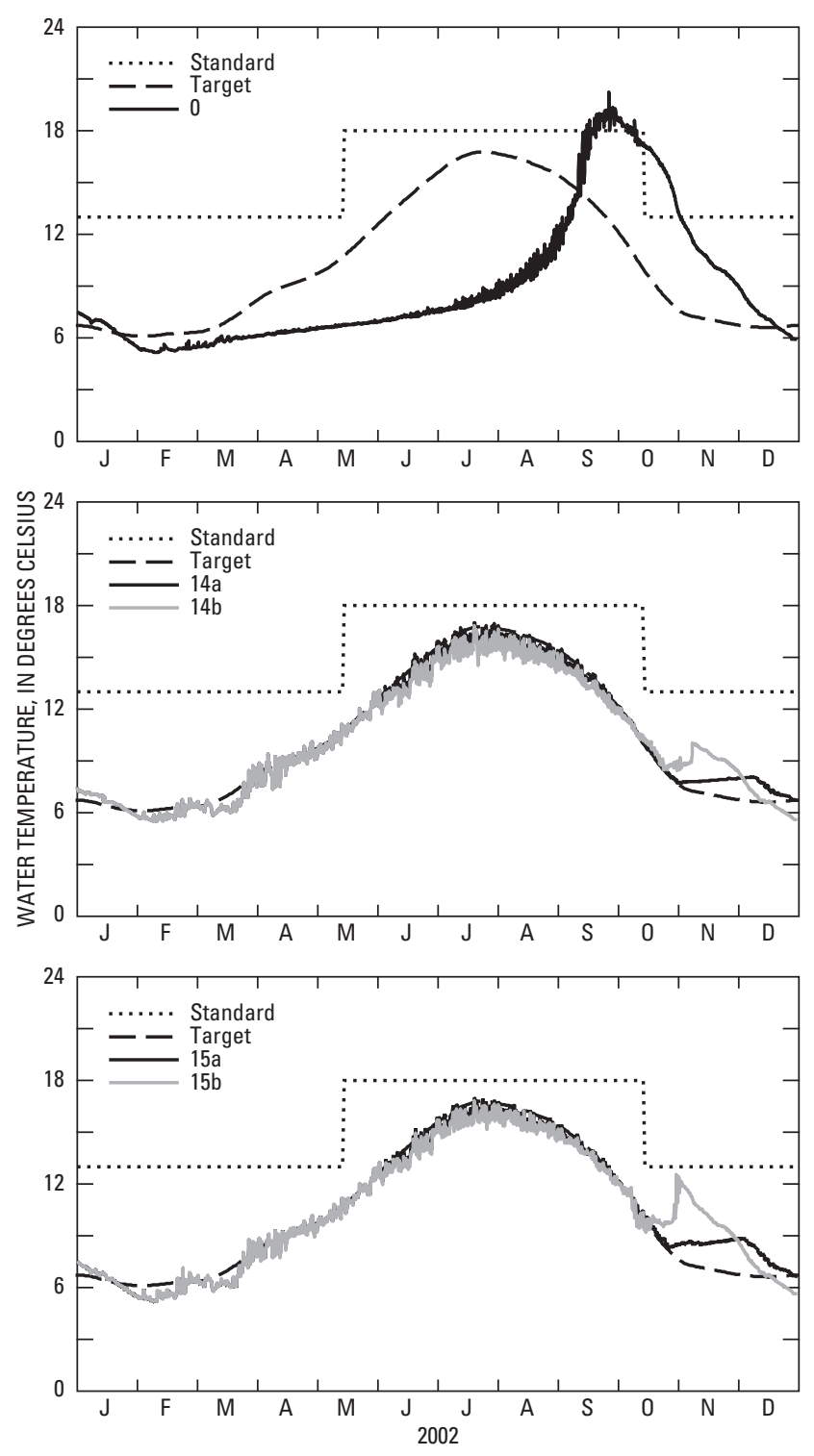

Figure 9. Simulated water temperature in the outflow for scenarios 0, 14, and 15, Hagg Lake, Oregon, 2002.

The relevant water temperature standard and target temperature are shown. Scenario details are shown in table 1.

Scenarios for 2002 with extra inflow from the Sain Creek tunnel or from pump-back resulted in lower annual average outflow water temperatures compared to their counterpart scenarios without the extra inflow. The difference averaged $-1.2^{\circ} \mathrm{C}$.

The 2001 scenarios that combined the effects of selective withdrawal and pump-back resulted in warmer outflow temperatures compared to the base case, as expected; that difference averaged $+1.2^{\circ} \mathrm{C}$. These scenarios also reduced the degree-days over the water temperature criteria, so that "a" scenarios were less than the criteria at all times, and "b" scenarios exceeded the criteria by less than 1 degree-day; using the simulated $7 \mathrm{dADM}$ water temperature, no exceedances of the standard were simulated.

\section{Dissolved Oxygen}

\section{Lake}

Adequate concentrations of dissolved oxygen in a lake are critical to the health of its aquatic biota. When Hagg Lake is thermally stratified, the hypolimnion loses contact with the atmosphere; dissolved oxygen in these deep isolated waters can become depleted due to aerobic decomposition of organic material (in the water column and surficial sediments) and due to ammonia nitrification. As the hypolimnion becomes anoxic, it becomes an inhospitable environment for many biota. In addition, loss of oxygen stimulates a range of reactions such as the hydrolysis and deamination of proteins to produce ammonia, the reduction and dissolution of iron and manganese oxides, and the desorption of any orthophosphate that had been adsorbed to those oxides.

All 2002 scenarios resulted in fewer days with low $(<1 \mathrm{mg} / \mathrm{L})$ dissolved oxygen in the lake (0 to 53.2 days), compared to the base case (64.2 days, table 3 ). Managing the lake releases in the 2002 scenarios to meet a downstream temperature target using selective withdrawal also affected the extent of in-lake anoxia. The extent of anoxia was greatest in 2002 scenarios that used only the original fixedelevation outlet (figs. 10, 11; table 3). With only one fixedelevation outlet, the model simulated an average of 46.1 days (SD 8.6 days) where dissolved oxygen concentrations were less than $1 \mathrm{mg} / \mathrm{L}$ somewhere in the lake. Using selective withdrawal, fewer days with those conditions occurred (16.3 days, SD 12.8 days). Clearly, the spatial and temporal extent of hypolimnetic anoxia in Hagg Lake could to some extent be controlled and minimized through careful utilization of selective withdrawal. The annual average volume of the lake with dissolved oxygen less than $1 \mathrm{mg} / \mathrm{L}$ was 0.36 percent (SD 0.18 percent) using only the original fixed outlet, and 0.08 percent (SD 0.11 percent) considering all scenarios with selective withdrawal. All these results were substantially lower than the base case, at 1.26 percent.

Different water levels in the 2002 model scenarios affected the timing and extent of anoxia in the lake's hypolimnion. Lake turnover marks the end of anoxia; the turnover date was calculated on the basis of a breakdown in the dissolved oxygen gradient: when at least a $1 \mathrm{mg} / \mathrm{L}$ difference in dissolved oxygen concentration over $1 \mathrm{~m}$ depth was no longer present. Turnover occurred on average on day 329.5 (November 25; SD 2.6 days) for the 2002 "b" scenarios, the scenarios with maximum future water demands, which left less water in the lake. The turnover date for the 2002 base case was similar, on day 329.2. Turnover occurred more than 2 weeks later for the 2002 "a" scenarios [average day 344.5 (December 10); SD 5.3 days], the scenarios which left more water in the lake. Supporting the idea that taking more water from the lake leads to an earlier turnover, it also was found that earlier turnover, on day 317.1 (November 13) occurred during the drought year, 2001, which had the lowest level ever recorded in Hagg Lake. 
Scenarios for 2002 with extra inflow via the Sain Creek tunnel resulted in higher annual average dissolved oxygen concentrations compared to their counterpart scenarios with the dam raise but without extra inflow; the difference averaged about $0.3 \mathrm{mg} / \mathrm{L}$. There was little difference in dissolved oxygen concentrations after adding extra inflows via pumpback compared to their counterpart scenarios without pumping for 2002 .
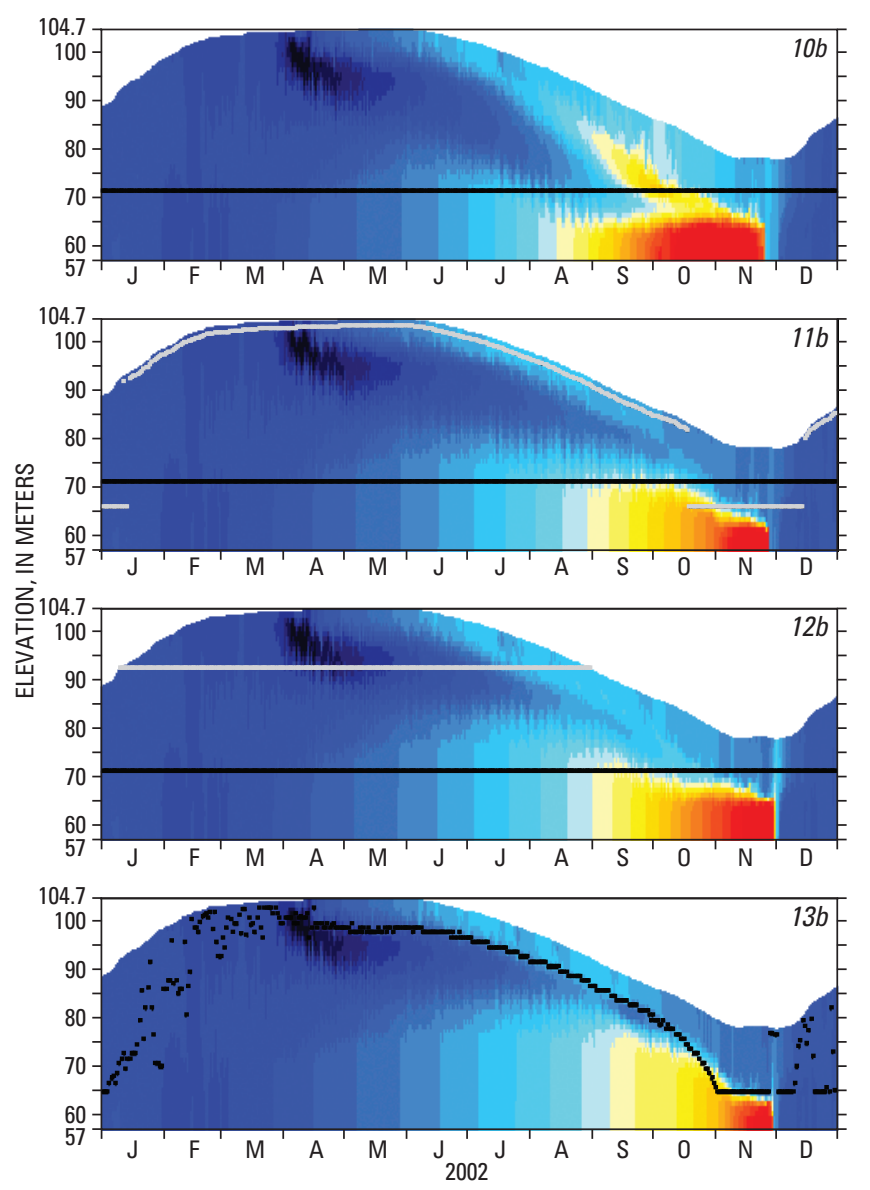

DISSOLVED OXYGEN, IN MILLIGRAMS PER LITER

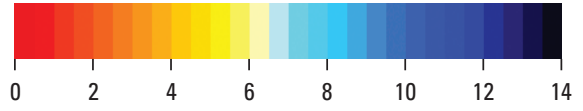

Figure 10. Simulated dissolved oxygen concentrations in the deepest part of the lake near the dam for 2002 scenarios 10b, $11 b, 12 b$, and 13b, Hagg Lake, Oregon.

The centerline elevations of the lake outlets are shown by the grey and black lines. Scenario 10b has one fixed-elevation outlet. Scenario $11 \mathrm{~b}$ has one fixed- and one variable-elevation outlet. Scenario 12b has two fixed-elevation outlets. Scenario 13b has one variable-elevation outlet. Refer to table 1 for more details on the scenarios.
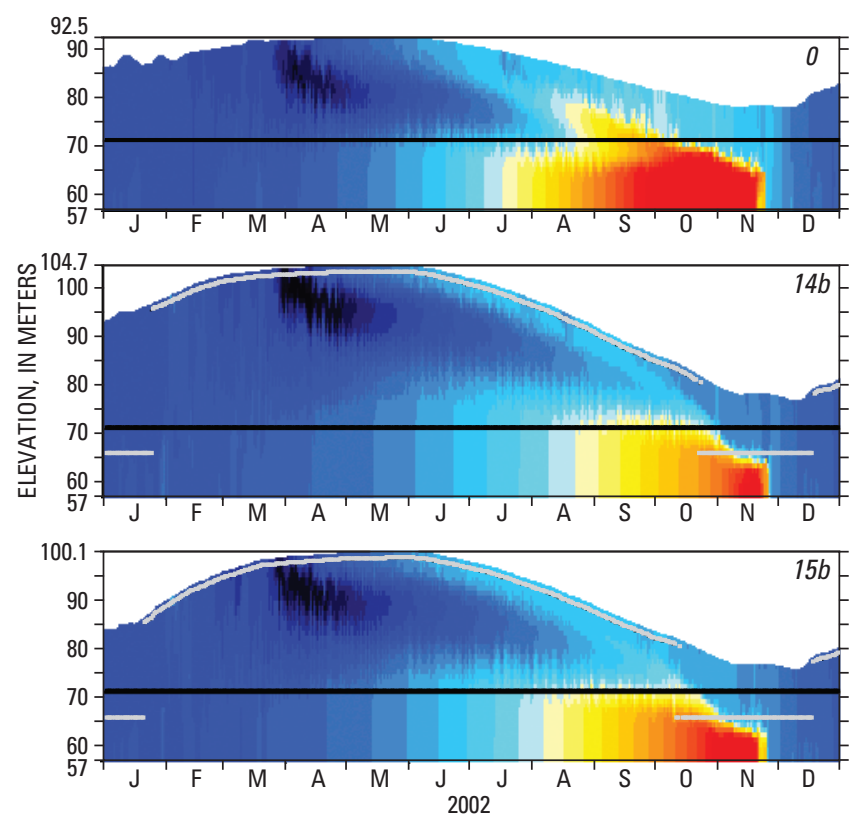

DISSOLVED OXYGEN, IN MILLIGRAMS PER LITER

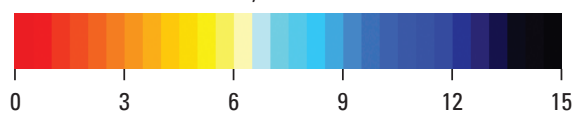

Figure 11. Simulated dissolved oxygen concentrations in the deepest part of the lake near the dam for 2002 base case (0) and pump-back scenarios (14b, 15b), Hagg Lake, Oregon. The centerline elevations of the lake outlets are shown by the grey and black lines. Scenario 0 has a fixed-elevation outlet, while $14 \mathrm{~b}$ and $15 \mathrm{~b}$ have both a fixed-elevation and variableelevation outlet. Scenario details are listed in table 1.

The 2001 scenarios that combined the effects of selective withdrawal and pumping resulted in higher annual average dissolved oxygen concentrations relative to the base case; that difference averaged $+0.3 \mathrm{mg} / \mathrm{L}$. The scenarios also resulted in a lower lake volume with low dissolved oxygen concentrations compared to the base case; that difference averaged -1.8 percent. These scenarios produced, on average, 33 fewer days with low dissolved oxygen, and the turnover occurred later in the year, trends that are similar to those from 2002. These results are consistent with the idea that having more water in the lake leads to later turnover.

\section{Outflow}

Previous modeling work showed that waters withdrawn from Hagg Lake have a seasonal cycle in dissolved oxygen concentrations, with high concentrations in winter and a minimum in late summer/autumn that typically is less than 
$5 \mathrm{mg} / \mathrm{L}$. However, the released waters are well-oxygenated in a turbulent aeration basin, causing the water in the creek downstream of Hagg Lake to be well-oxygenated and close to saturation (Sullivan and Rounds, 2005). With the structural changes under consideration, some of the outflow may be routed directly into a pipe rather than into the aeration basin. Dissolved oxygen concentrations in the outflow, therefore, are important to consider, especially because other chemical constituents such as ammonia, dissolved iron and manganese, and phosphorus may be present in heightened levels in water with low dissolved oxygen. Furthermore, if CWS flow-augmentation water is released directly to a pipe, some subsequent method of aeration may be necessary before that water is returned to the river.

Similar to the temporal patterns of dissolved oxygen in the lake, the outflow concentrations in all 2002 scenarios were highest in winter and spring, and reached their lowest concentrations in autumn (figs. 12, 13). Scenarios with the "a" water demands reached lower minimum dissolved oxygen concentrations in the outflow $(2.71 \mathrm{mg} / \mathrm{L} ; \mathrm{SD} 1.44 \mathrm{mg} / \mathrm{L})$, with minima later in the year (day 327.4; SD 17.8 days), compared to scenarios with "b" maximum water demands, which had higher minimum concentrations $(4.17 \mathrm{mg} / \mathrm{L}$; SD $1.12 \mathrm{mg} / \mathrm{L}$ ) and earlier dates for those minima (day 290.6; SD 17.6 days). This pattern is a direct consequence of the later turnover of the lake in the "a" scenarios, where the nearbottom waters remain isolated and are exposed to oxygenconsuming reactions for a longer period of time. No attempt was made in these scenarios to avoid low concentrations of dissolved oxygen when positioning the sliding-gate outlets (see Appendix A).

Scenarios for 2002 with extra inflow from the Sain Creek tunnel and from pump-back resulted in higher annual average outflow dissolved oxygen concentrations compared to their counterpart scenarios with the dam raise but without extra inflow. The difference averaged about $+1.18 \mathrm{mg} / \mathrm{L}$ for the inflows from the Sain Creek tunnel and $+0.75 \mathrm{mg} / \mathrm{L}$ for the pump-back scenario. The outflow minimum dissolved oxygen concentrations also increased in both of these scenario groups; they increased by an average of $+1.25 \mathrm{mg} / \mathrm{L}$ with inflows from the Sain Creek tunnel and by $+0.55 \mathrm{mg} / \mathrm{L}$ using pump-back. When compared to the 2002 base case, scenarios with pump-back water had minimum dissolved oxygen concentrations that were lower by an average of $1.8 \mathrm{mg} / \mathrm{L}$.

The 2001 scenarios that combined the effects of selective withdrawal and pumping resulted in lower minimum dissolved oxygen concentrations compared to the base case; the minimums changed by an average of $-4.4 \mathrm{mg} / \mathrm{L}$. The lowest dissolved oxygen concentration in the outflow for all scenarios was $0.18 \mathrm{mg} / \mathrm{L}$ for scenario $14 \mathrm{a}$ in 2001.
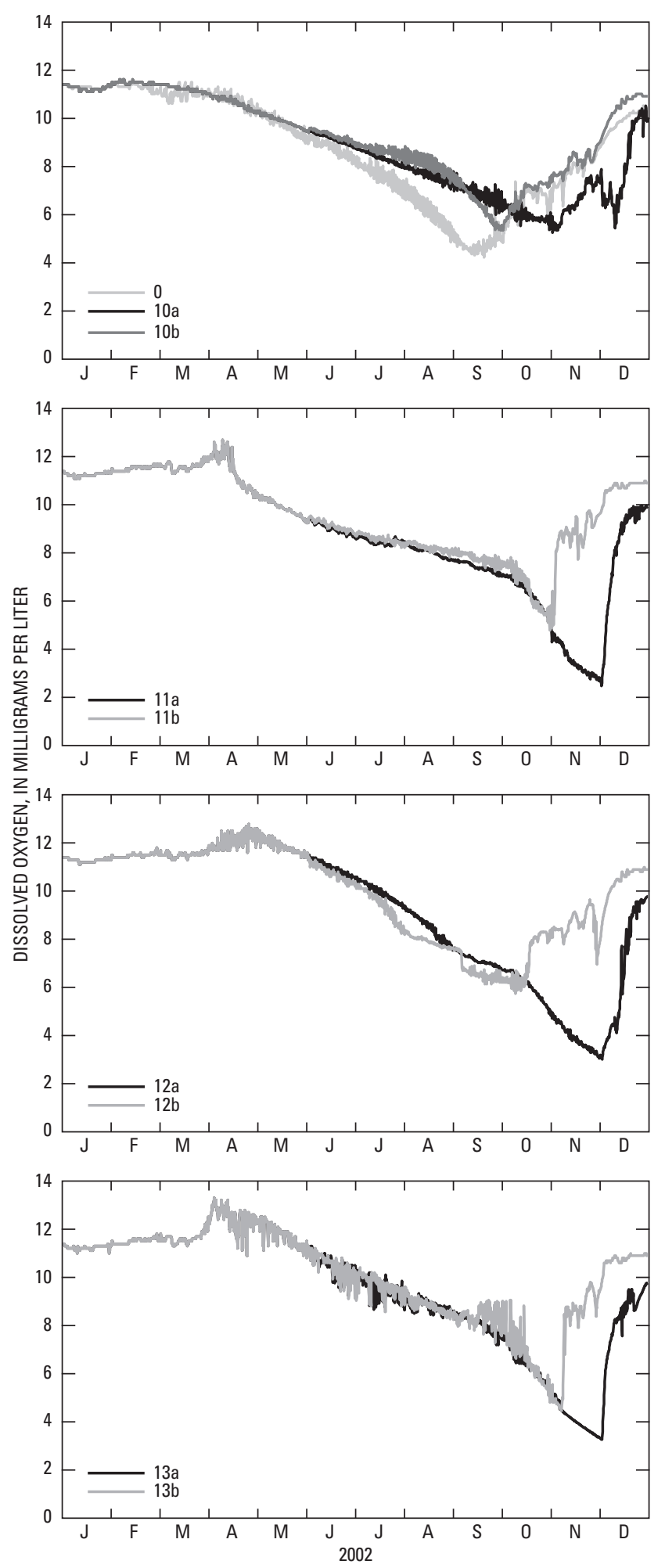

Figure 12. Simulated dissolved oxygen concentrations in the outflow for scenarios 10, 11, 12, and 13, Hagg Lake, Oregon, 2002.

Scenario details are listed in table 1. 

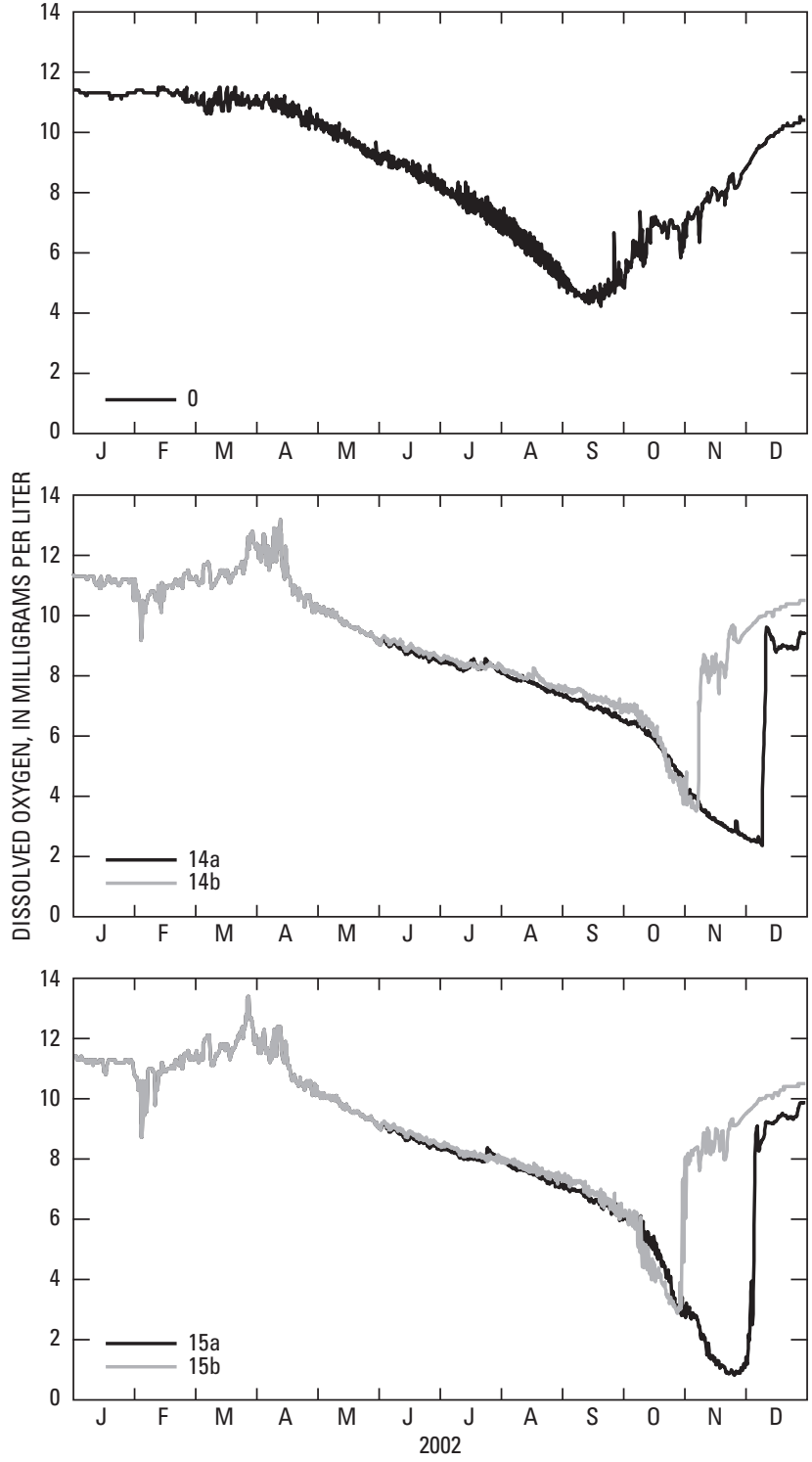

Figure 13. Simulated dissolved oxygen concentrations in the outflow for scenarios 0, 14, and 15, Hagg Lake, Oregon, 2002. Scenario details are listed in table 1.

\section{Ammonia}

\section{Lake}

High concentrations of ammonia can be toxic to biota, can lead to low dissolved oxygen concentrations via nitrification, and generally are not desirable in water designated for Scoggins Creek or downstream users. In drinking water treatment plants, ammonia can affect disinfection efficiency, result in nitrite formation, cause the failure of manganese removal filters, and produce taste and odor problems (World Health Organization, 2003). In Hagg Lake, concentrations are low through much of the lake, but substantial concentrations of ammonia can accumulate in an anoxic hypolimnion (Sullivan and Rounds, 2005).

The 2002 base case had an annual average ammonia concentration of $12.9 \mu \mathrm{g} / \mathrm{L}$ as $\mathrm{N}$ and a maximum hypolimnetic ammonia concentration of $251 \mu \mathrm{g} / \mathrm{L}$ as N. All other 2002 scenarios resulted in lower annual average ammonia concentrations (10.1 to $12.2 \mu \mathrm{g} / \mathrm{L}$ as $\mathrm{N}$; table 5) and lower maximum hypolimnetic ammonia concentrations (10.6 to $229 \mu \mathrm{g} / \mathrm{L}$ as $\mathrm{N}$; table 5). The decrease in ammonia concentrations correlated well with shortened periods of anoxia in the hypolimnion, except for the 2002 pump-back scenarios 14 and 15 (fig. 14).

Selective withdrawal helped to minimize the ammonia concentration in the hypolimnion (figs. 15, 16; table 5). The annual average ammonia concentration for scenarios using only the original fixed-elevation outlet was $11.6 \mu \mathrm{g} / \mathrm{L}$ as $\mathrm{N}$ (SD $0.3 \mu \mathrm{g} / \mathrm{L}$ as $\mathrm{N}$ ); for scenarios with selective withdrawal, the annual average concentration was $10.8 \mu \mathrm{g} / \mathrm{L}$ as $\mathrm{N}(\mathrm{SD} 0.7 \mu \mathrm{g} / \mathrm{L}$ as $\mathrm{N}$ ).

Scenarios for 2002 with extra inflow from pump-back resulted in higher annual average ammonia concentrations compared to their counterpart scenarios without extra inflow; the difference averaged about $+1.4 \mu \mathrm{g} / \mathrm{L}$ as $\mathrm{N}$. There was little difference in the annual average ammonia concentration after adding extra inflows via the Sain Creek tunnel for 2002.

The 2001 scenarios, which combined the effects of selective withdrawal and pump-back, resulted in lower annual average ammonia concentrations compared to the base case; the decrease averaged $-1.8 \mu \mathrm{g} / \mathrm{L}$ as $\mathrm{N}$.

\section{Outflow}

Concentrations of ammonia in the outflow for 2002 scenarios were low, with annual averages generally ranging between 9.3 and $13.3 \mu \mathrm{g} / \mathrm{L}$ as $\mathrm{N}$ (table 4). With only one fixed outlet, the highest concentration of ammonia in the outflow occurred during turnover (fig. 17, scenarios 0 and 10), when the ammonia concentrated in the hypolimnion became mixed through the lake. However, annual average concentrations of ammonia in the outflow were not distinctly different among the various scenarios (figs. 17, 18).

Scenarios for 2002 with extra inflow from the Sain Creek tunnel resulted in a small $(-0.5 \mu \mathrm{g} / \mathrm{L}$ as $\mathrm{N})$ decrease in the annual average outflow ammonia concentration compared to their counterpart scenarios without extra inflow. On the other hand, extra inflow from pump-back resulted in an increase in the annual average outflow ammonia concentration (by $+1.3 \mu \mathrm{g} / \mathrm{L}$ as $\mathrm{N})$. 
Table 5. In-lake annual scenario results for ammonia, orthophosphate, chlorophyll $a$, and blue-green algae, Hagg Lake, Oregon.

[The length of the blue-green algae bloom was calculated as the time their concentration was greater than 0.5 gram per cubic meter. The photic zone was estimated to include the top 10 meters of the water column, on the basis of light profiles measured in Hagg Lake. Abbreviations: $\mu \mathrm{g} / \mathrm{L}$, microgram per liter; $\mathrm{N}$, nitrogen; $\mathrm{P}$, phosphorus]

\begin{tabular}{|c|c|c|c|c|c|c|c|}
\hline \multicolumn{2}{|c|}{ Scenario } & $\begin{array}{c}\text { Ammonia, } \\
\text { mean } \\
\text { whole-lake } \\
(\mu \mathrm{g} / \mathrm{L} \text { as } N)\end{array}$ & $\begin{array}{c}\text { Ammonia, } \\
\text { maximum in } \\
\text { hypolimnion } \\
\text { ( } \mu \mathrm{g} / \mathrm{L} \text { as } \mathrm{N} \text { ) }\end{array}$ & $\begin{array}{c}\text { Orthophosphate, } \\
\text { mean, } \\
\text { whole-lake } \\
(\mu \mathrm{g} / \mathrm{L} \text { as } \mathrm{P})\end{array}$ & $\begin{array}{c}\text { Orthophosphate, } \\
\text { mean, } \\
\text { photic zone } \\
(\mu \mathrm{g} / \mathrm{L} \text { as } \mathrm{P})\end{array}$ & $\begin{array}{c}\text { Chlorophyll a, } \\
\text { photic zone } \\
(\mu \mathrm{g} / \mathrm{L})\end{array}$ & $\begin{array}{c}\text { Length of } \\
\text { blue-green } \\
\text { algal bloom } \\
\text { (days) }\end{array}$ \\
\hline \multicolumn{8}{|c|}{2002} \\
\hline 0 & Base & 12.9 & 251 & 5.05 & 4.17 & 1.65 & 66.4 \\
\hline \multirow{2}{*}{1} & $\mathrm{a}$ & 11.9 & 147 & 5.35 & 4.23 & 1.45 & 69.2 \\
\hline & $\mathrm{b}$ & 12.0 & 212 & 5.22 & 4.12 & 1.54 & 70.2 \\
\hline \multirow{2}{*}{2} & $\mathrm{a}$ & 10.6 & 28.8 & 5.41 & 4.27 & 1.22 & 43.0 \\
\hline & $\mathrm{b}$ & 10.5 & 201 & 5.37 & 4.28 & 1.18 & 29.0 \\
\hline \multirow{2}{*}{3} & $\mathrm{a}$ & 10.7 & 39.9 & 5.51 & 4.32 & 1.25 & 47.0 \\
\hline & $\mathrm{b}$ & 10.7 & 97.9 & 5.49 & 4.38 & 1.29 & 37.0 \\
\hline \multirow{2}{*}{4} & $\mathrm{a}$ & 10.6 & 13.6 & 5.61 & 4.31 & 1.36 & 64.8 \\
\hline & $\mathrm{b}$ & 10.6 & 228 & 5.56 & 4.31 & 1.37 & 60.4 \\
\hline \multirow{2}{*}{5} & $\mathrm{a}$ & 11.4 & 99.3 & 5.45 & 4.26 & 1.39 & 64.2 \\
\hline & $\mathrm{b}$ & 11.8 & 189 & 5.26 & 4.09 & 1.53 & 69.6 \\
\hline \multirow{2}{*}{6} & $\mathrm{a}$ & 10.5 & 11.3 & 5.51 & 4.28 & 1.17 & 42.4 \\
\hline & $\mathrm{b}$ & 10.4 & 129 & 5.43 & 4.29 & 1.05 & 0.0 \\
\hline \multirow{2}{*}{7} & $\mathrm{a}$ & 10.5 & 11.2 & 5.61 & 4.23 & 1.27 & 54.0 \\
\hline & $\mathrm{b}$ & 10.5 & 61.3 & 5.55 & 4.29 & 1.28 & 46.2 \\
\hline \multirow{2}{*}{8} & $\mathrm{a}$ & 10.5 & 10.9 & 5.69 & 4.31 & 1.29 & 58.6 \\
\hline & $\mathrm{b}$ & 10.4 & 169 & 5.60 & 4.31 & 1.30 & 49.6 \\
\hline \multirow{2}{*}{9} & a & 11.3 & 43.1 & 5.67 & 4.37 & 1.37 & 64.6 \\
\hline & $\mathrm{b}$ & 11.7 & 208 & 5.43 & 4.17 & 1.53 & 70.4 \\
\hline \multirow{2}{*}{10} & $\mathrm{a}$ & 11.2 & 40.3 & 5.63 & 4.38 & 1.36 & 64.4 \\
\hline & $\mathrm{b}$ & 11.6 & 209 & 5.39 & 4.20 & 1.52 & 70.4 \\
\hline \multirow{2}{*}{11} & $\mathrm{a}$ & 10.4 & 10.7 & 5.64 & 4.43 & 1.12 & 38.2 \\
\hline & b & 10.3 & 148 & 5.50 & 4.36 & 1.08 & 0.0 \\
\hline \multirow{2}{*}{12} & $\mathrm{a}$ & 10.5 & 10.7 & 5.77 & 4.35 & 1.31 & 62.0 \\
\hline & $\mathrm{b}$ & 10.5 & 64.6 & 5.63 & 4.34 & 1.31 & 49.4 \\
\hline \multirow{2}{*}{13} & $\mathrm{a}$ & 10.3 & 10.6 & 5.83 & 4.44 & 1.27 & 52.0 \\
\hline & $\mathrm{b}$ & 10.1 & 68.3 & 5.62 & 4.27 & 1.31 & 39.4 \\
\hline \multirow{2}{*}{14} & $\mathrm{a}$ & 12.0 & 11.9 & 9.27 & 6.87 & 1.55 & 50.2 \\
\hline & $\mathrm{b}$ & 11.8 & 27.2 & 9.20 & 6.86 & 1.54 & 23.2 \\
\hline \multirow{2}{*}{15} & $\mathrm{a}$ & 12.2 & 38.2 & 6.49 & 4.96 & 1.79 & 42.4 \\
\hline & $\mathrm{b}$ & 12.2 & 229 & 6.44 & 5.01 & 1.75 & 1.4 \\
\hline \multicolumn{8}{|c|}{2001} \\
\hline 0 & Base & 12.6 & 183 & 4.68 & 4.23 & 1.06 & 42.6 \\
\hline \multirow{2}{*}{14} & $\mathrm{a}$ & 10.8 & 106 & 5.28 & 4.46 & 0.88 & 0.0 \\
\hline & $\mathrm{b}$ & 10.7 & 263 & 5.17 & 4.37 & 0.96 & 0.0 \\
\hline \multirow{2}{*}{15} & $\mathrm{a}$ & 10.9 & 121 & 5.28 & 4.47 & 0.89 & 0.0 \\
\hline & b & 10.8 & 281 & 5.18 & 4.40 & 0.96 & 0.0 \\
\hline
\end{tabular}




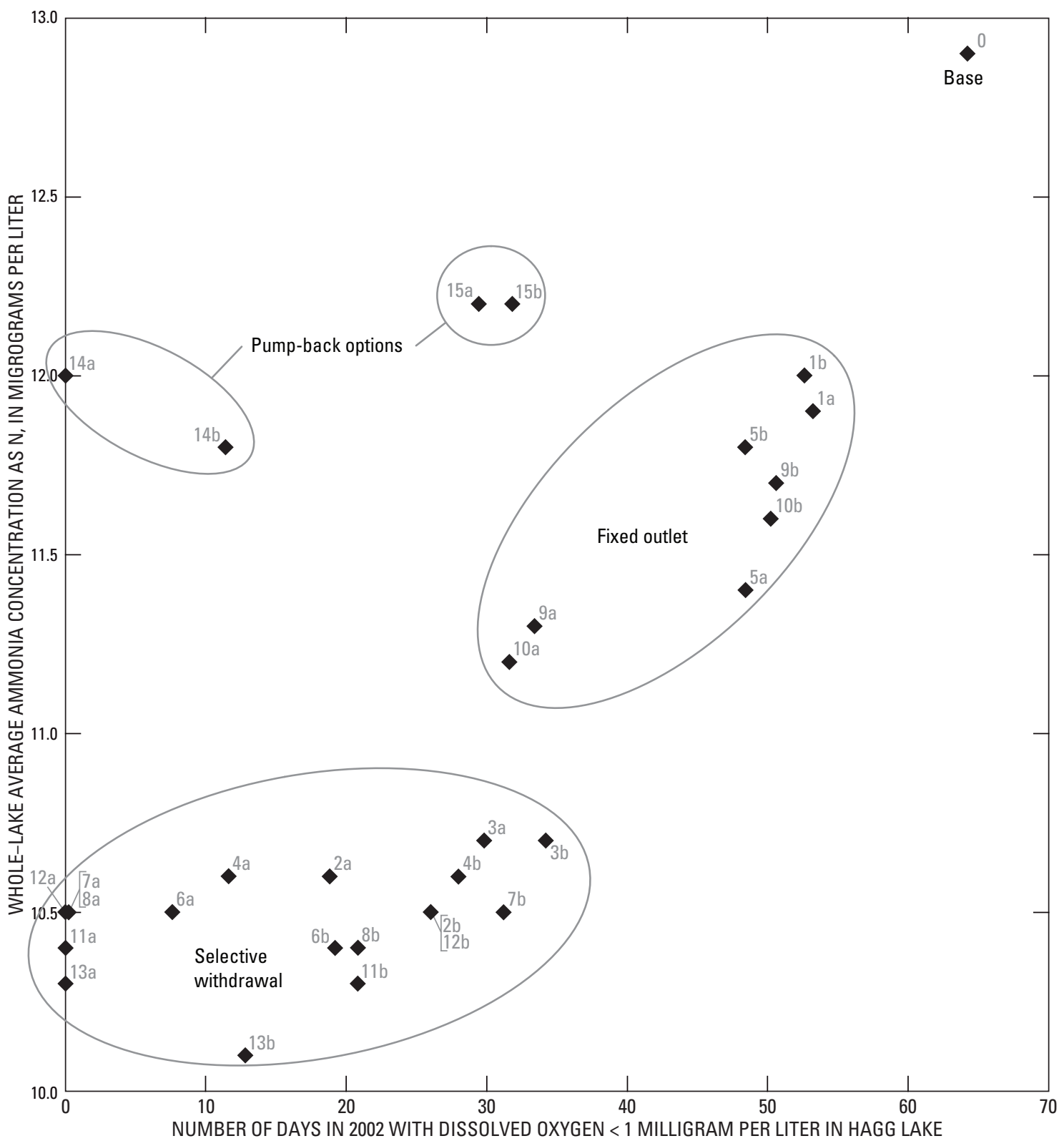

Figure 14. Annual whole-lake average ammonia concentration and the number of days in 2002 with dissolved oxygen concentrations anywhere in the lake less than $1 \mathrm{mg} / \mathrm{L}$, Hagg Lake, Oregon.

Results from all 2002 scenarios are included, and are grouped with others of similar characteristics. Refer to table 1 for scenario details. 

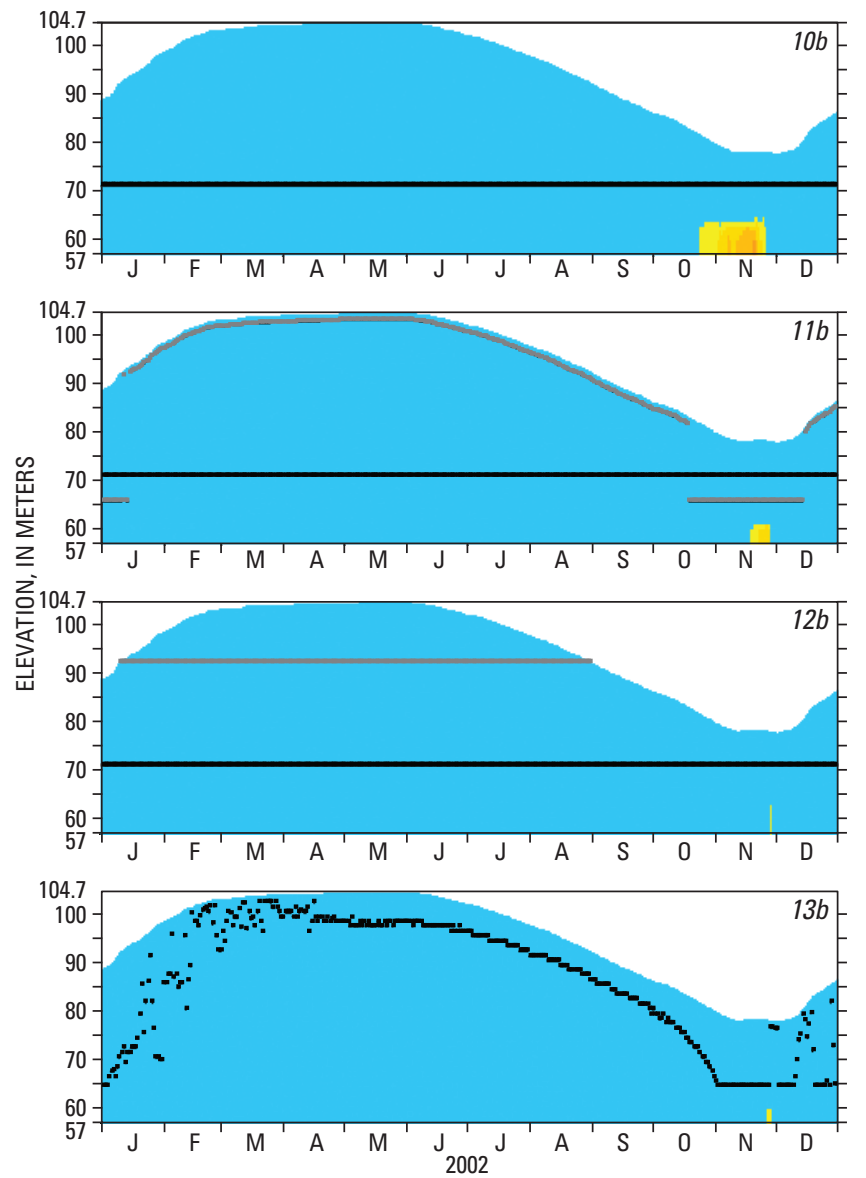

AMMONIA AS N, IN MICROGRAMS PER LITER

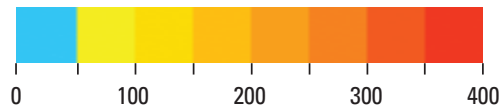

Figure 15. Simulated ammonia concentrations in the deepest part of the lake near the dam for 2002 scenarios 10b, 11b, 12b, and $13 \mathrm{~b}$, Hagg Lake, Oregon.

The centerline elevations of the lake outlets are shown by the dark lines. Scenario 10b has one fixed-elevation outlet. Scenario $11 \mathrm{~b}$ has one fixed- and one variable-elevation outlet. Scenario $12 \mathrm{~b}$ has two fixed-elevation outlets. Scenario $13 \mathrm{~b}$ has one variable-elevation outlet. Refer to table 1 for more details on the scenarios.
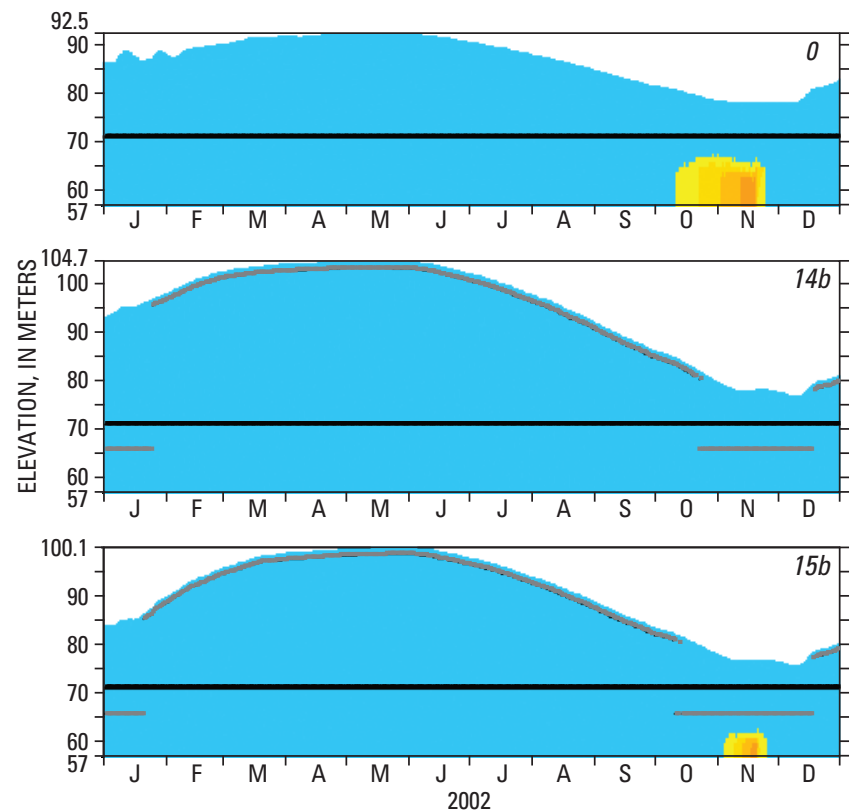

AMMONIA AS N, IN MICROGRAMS PER LITER

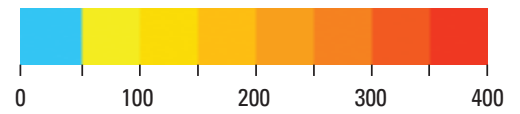

Figure 16. Simulated ammonia concentrations in the deepest part of the lake near the dam for 2002 base case (0) and pumpback scenarios (14b, 15b), Hagg Lake, Oregon.

The centerline elevations of the lake outlets are shown by the dark lines. Scenario 0 has a fixed-elevation outlet, while $14 \mathrm{~b}$ and $15 \mathrm{~b}$ have both a fixed-elevation and variable-elevation outlet. Scenario details are listed in table 1. The color scale is set to highlight accumulation of ammonia in the lake's hypolimnion, if present. 

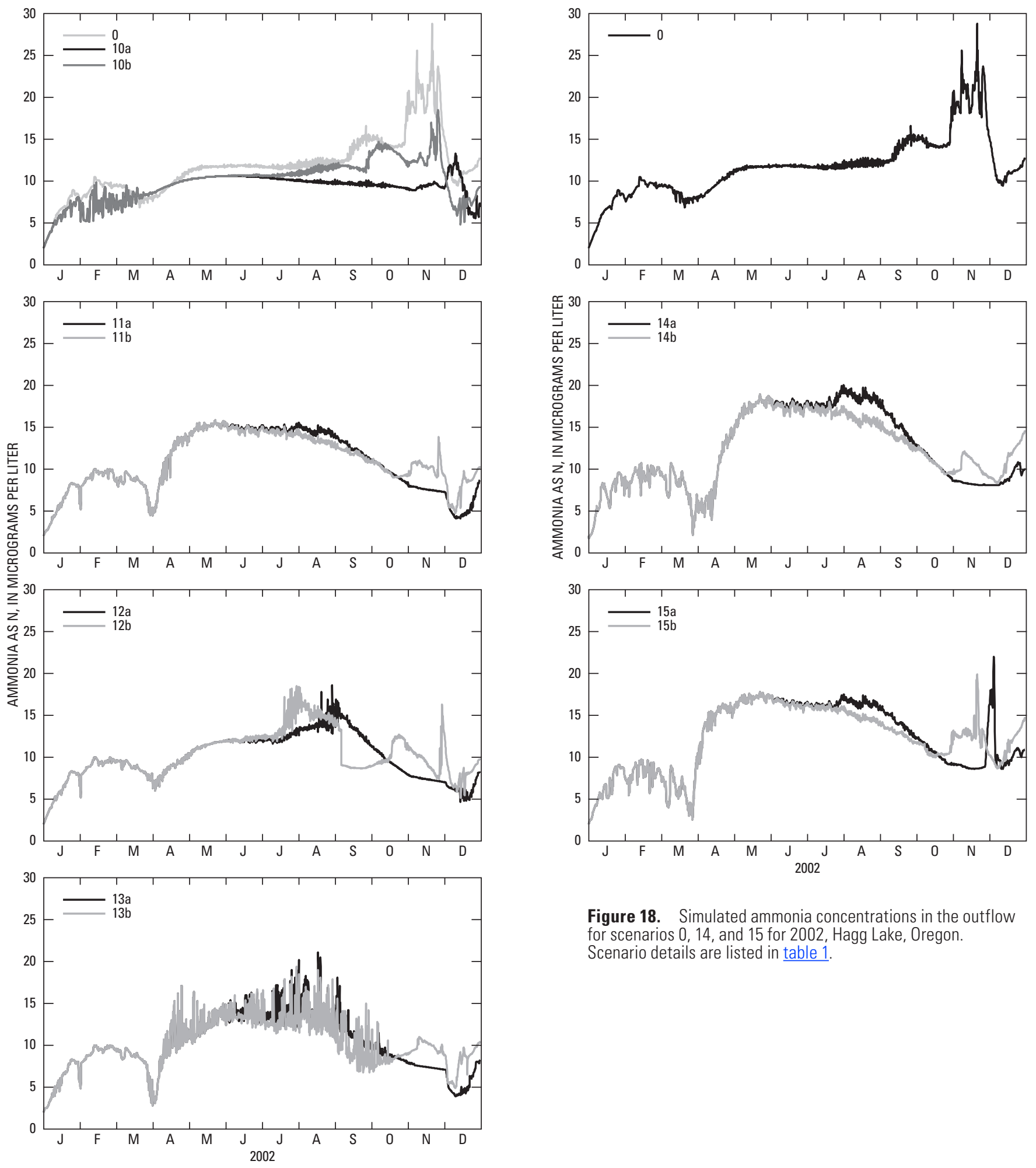

Figure 18. Simulated ammonia concentrations in the outflow for scenarios 0, 14, and 15 for 2002, Hagg Lake, Oregon. Scenario details are listed in table 1.

Figure 17. Simulated ammonia concentrations in the outflow for scenarios 0, 10, 11, 12, and 13 for 2002, Hagg Lake, Oregon. Scenario details are listed in table 1. 


\section{Chlorophyll a and Orthophosphate}

\section{Lake}

Excluding some pump-back scenarios, 2002 scenarios had lower annual average chlorophyll $a$ concentrations in the photic zone (1.05 to $1.54 \mu \mathrm{g} / \mathrm{L}$ ) compared to the 2002 base case $(1.65 \mu \mathrm{g} / \mathrm{L})$. A sensitivity analysis of the Hagg Lake model (Sullivan and Rounds, 2005) showed that blue-green algae were temperature sensitive, preferring warmer water, so it is possible that the overall cooler lake temperatures produced in the model scenarios caused a decrease in algal growth. Export of algae downstream in scenarios with selective withdrawal, which withdrew water from the epilimnion where algae grew, also could have contributed to lower chlorophyll $a$ concentrations. Indeed, 2002 scenarios with selective withdrawal capability had shorter periods of blue-green algal concentrations greater than $0.5 \mathrm{~g} / \mathrm{m}^{3}(40.5$ days; SD 19.9 days), compared to those using just the original fixed-elevation outlet (67.9 days; SD 2.9 days).

All 2002 scenarios had higher average whole-lake orthophosphate concentrations (5.22 to $9.27 \mu \mathrm{g} / \mathrm{L}$ as $\mathrm{P}$ ) compared to the 2002 base case $(5.05 \mu \mathrm{g} / \mathrm{L}$ as P). Algae use orthophosphate for growth, and, except for higher orthophosphate concentrations with the pump-back option (described below), some of the higher orthophosphate concentrations probably are directly related to the lower chlorophyll $a$ and algal concentrations in the scenarios.

Scenarios for 2002 with extra inflow from pump-back resulted in higher photic-zone average chlorophyll $a$ and whole-lake average orthophosphate concentrations compared to their counterpart scenarios with the dam raise, but without extra inflow. The difference was $+0.4 \mu \mathrm{g} / \mathrm{L}$ for chlorophyll $a$ and $+3.8 \mu \mathrm{g} / \mathrm{L}$ as $\mathrm{P}$ for orthophosphate. This is a 69 percent increase in whole-lake average orthophosphate; average total phosphorus concentrations also increased, by about 39 percent. The increase in phosphorus loading produced an increase in the duration of the blue-green algal bloom and the aforementioned increase in chlorophyll $a$. In this model, the greatest uncertainty in the model's predictions involves algal dynamics, and this should be considered when interpreting the results. However, the potential of increasing the size and duration of algal blooms in the reservoir is a concern to downstream water users (taste and odor issues, for instance) and should be considered in implementing or managing this option. There was little difference in the photic-zone average chlorophyll $a$ or whole-lake average orthophosphate concentration for the scenarios with added inflows from a Sain Creek tunnel compared to their counterpart scenarios with the dam raise, but without extra inflow.
The 2001 scenarios that combined the effects of selective withdrawal and pump-back resulted in slightly higher whole-lake average orthophosphate concentrations and slightly lower photic-zone average chlorophyll $a$ concentrations compared to the base case; the differences were $+0.5 \mu \mathrm{g} / \mathrm{L}$ as $\mathrm{P}$ and $-0.1 \mu \mathrm{g} / \mathrm{L}$, respectively. Blue-green blooms did not exceed $0.5 \mathrm{~g} / \mathrm{m}^{3}$ in these scenarios, possibly due to cooler epilimnetic temperatures. The increase in orthophosphate was not as great in 2001, in part because the available pump-back water had lower orthophosphate concentrations compared to 2002.

\section{Outflow}

Use of selective withdrawal typically increased the concentration of chlorophyll $a$ in the 2002 scenario outflows compared to the base case and other scenarios using the original outlet. The annual average outflow chlorophyll $a$ concentration was $0.83 \mu \mathrm{g} / \mathrm{L}$ (SD $0.17 \mu \mathrm{g} / \mathrm{L}$ ) for scenarios with selective withdrawal and $0.31 \mu \mathrm{g} / \mathrm{L}$ (SD $0.14 \mu \mathrm{g} / \mathrm{L}$ ) for scenarios using only the original fixed-elevation outlet. This result is directly attributable to the fact that selective withdrawal drew water from near the lake's surface, where the algae generally reside (because they require light for growth), while the water at the depth of the original outlet typically was well below the photic zone and therefore had a lower chlorophyll $a$ concentration.

Conversely, the use of selective withdrawal decreased the concentration of orthophosphate in the scenario outflows (average $5.36 \mu \mathrm{g} / \mathrm{L}$ as $\mathrm{P}$; SD $0.42 \mu \mathrm{g} / \mathrm{L}$ as $\mathrm{P}$; excluding pumpback runs) compared to the base case. The scenarios using only the original fixed outlet had higher concentrations of orthophosphate (average $6.93 \mu \mathrm{g} / \mathrm{L}$ as $\mathrm{P}$; SD $0.36 \mu \mathrm{g} / \mathrm{L}$ as P) compared to the base case.

The lower chlorophyll $a$ and higher orthophosphate concentrations from scenarios with only the original fixed outlet, as well as the general inverse relation between orthophosphate and chlorophyll $a$ in the outflow for the scenarios, is illustrated in figure 19. In that figure, the points for scenarios with only one fixed outlet $(0,1,5,9$, and 10$)$ all lie on or near the same line. The relative position of these points is due to the average depth of the withdrawals and the fact that higher algae concentrations and therefore lower orthophosphate concentrations are found at shallower depths. Scenario 0 , the base case, is the shallowest of these scenarios,

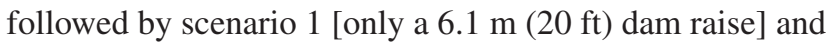
scenarios 5, 9, and 10. The "a" scenarios result in a deeper lake than the "b" scenarios, which helps explain the rest of this trend. Most of the selective withdrawal scenarios lie in the opposite direction, due to the increased export of shallow water where the algae grow.

Scenarios for 2002 with extra inflow from the pumpback option produced increases in both chlorophyll $a$ and orthophosphate in the outflow (fig. 19), indicating again that 
the importation of extra phosphorus led to slightly higher levels of algal growth in that year. The $12.2 \mathrm{~m} \mathrm{(40} \mathrm{ft)} \mathrm{dam}$ raise with pump-back (scenario 14) produced higher outflow

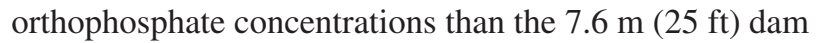
raise with pump-back (scenario 15), due to the fact that the $12.2 \mathrm{~m} \mathrm{(40} \mathrm{ft)} \mathrm{dam} \mathrm{raise} \mathrm{required} \mathrm{more} \mathrm{pump-back} \mathrm{of} \mathrm{the}$ higher phosphorus Tualatin River water to fill the larger reservoir. Extra inflow from the Sain Creek tunnel did not appreciably change either the annual average chlorophyll $a$ or orthophosphate concentration in the outflow in scenarios that used that option.

The 2001 scenarios that combined the effects of selective withdrawal and pump-back resulted in slightly higher average outflow orthophosphate concentrations and slightly lower chlorophyll $a$ concentrations compared to the base case; the changes averaged $+0.7 \mu \mathrm{g} / \mathrm{L}$ as $\mathrm{P}$ and $-0.3 \mu \mathrm{g} / \mathrm{L}$, respectively.

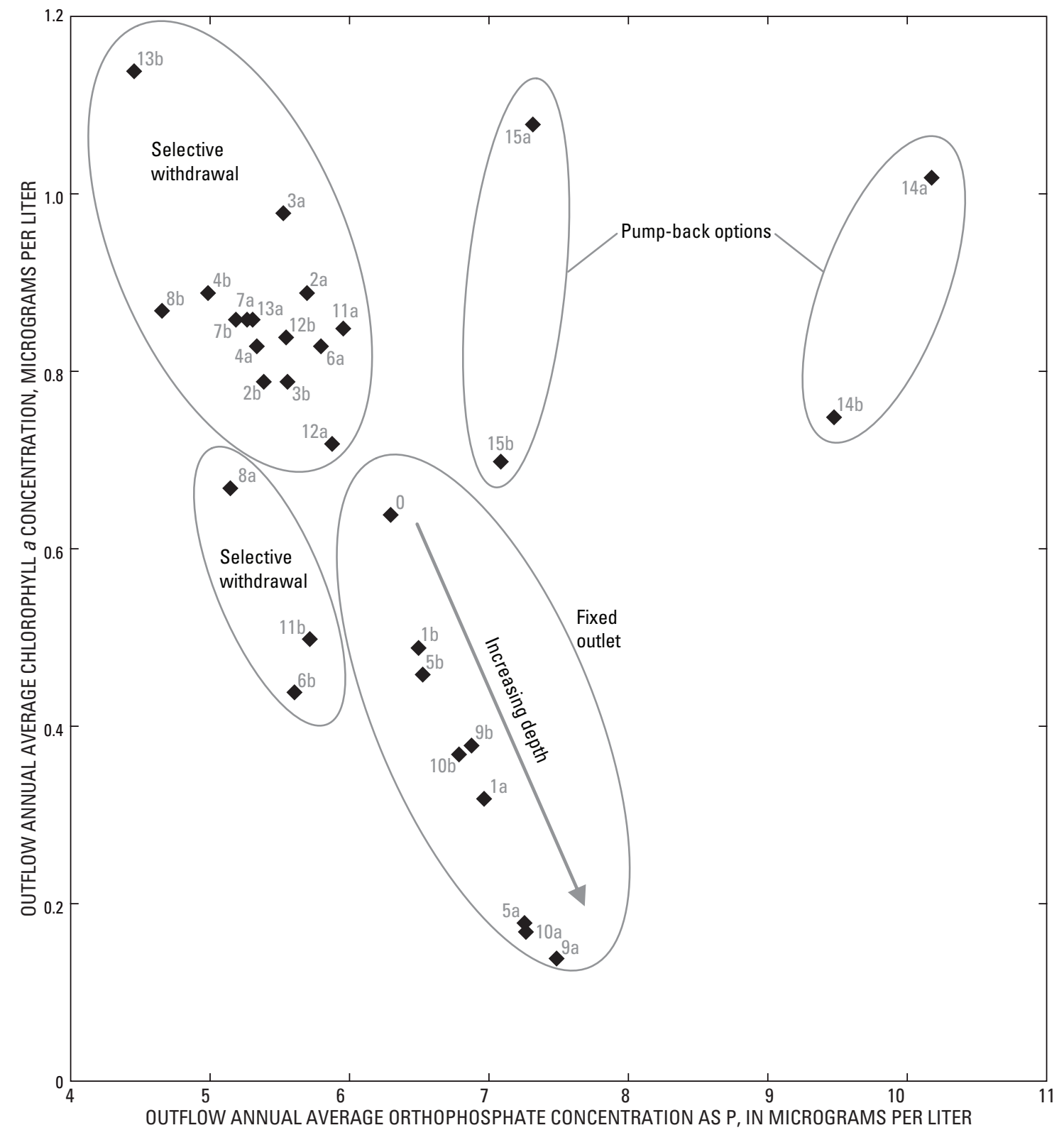

Figure 19. Annual average orthophosphate and chlorophyll a concentrations in the outflow, Hagg Lake, Oregon. Results from all 2002 scenarios are included. Scenarios having only one lake outlet are labeled and fall together. Scenarios using selective withdrawal generally are above and to the left of the base case. The pump-back scenarios fall outside of these groups. 


\section{Implications for Future Dam Operation Quality of Extra Inflow Water}

With an increasing human population in the area comes increasing demand for water of high quality. Use of the USGS Hagg Lake water quality model has allowed the examination of the water quality effects of potential modifications to storage in Hagg Lake, including a dam raise, installation of additional outlets, and introduction of additional inflows. The model is able to address a number of water quality concerns, including the quality of the lake's water and the quality of water delivered to downstream users and to lower Scoggins Creek.

The model's predicted changes in water quality may be evaluated with water quality goals in mind. These goals may vary depending on the intended use of the water. Some changes that generally are considered to be positive by many users include: decreasing the extent of anoxia in the lake; decreasing ammonia concentrations in the lake; reducing blue-green algae blooms in the lake; meeting a downstream temperature target; lowering concentrations of ammonia, blue-green algae, and total organic carbon in the outflow; and increasing concentrations of dissolved oxygen in the outflow.

For some measures, all scenarios showed improvements compared to the base case. For example, all scenarios had a lower annual average lake volume where dissolved oxygen concentrations were less than $1 \mathrm{mg} / \mathrm{L}$, and had fewer days with low dissolved oxygen conditions. All scenarios produced lower annual average concentrations of ammonia. For other measures, such as chlorophyll $a$ in the lake and the outflow, some scenarios showed improvement while others did not. The modifications that generally had an important effect on water quality can be summarized into three main groups: the amount of water in the reservoir; the quality of the augmented inflows; and the number, type, and operation of the lake's outlets.

\section{Amount of Water in the Reservoir}

The amount of water in the reservoir depended on factors such as the height of the dam, whether any additional inflows entered the lake from a Sain Creek tunnel or a pump-back option, and the amount of water released from the lake.

Model scenarios with lower lake levels generally produced warmer annual average lake water temperatures, earlier lake turnover, and more ammonia in the hypolimnion, compared to scenarios with higher water surface elevations. Lower lake levels produced outflows that were more likely to exceed downstream water temperature criteria and had earlier and higher minimum dissolved oxygen concentrations, which was related to earlier lake turnover.
Although the amount of inflow water affects lake level, which can affect water quality processes in Hagg Lake as discussed above, the quality of the inflow water also affects the lake. Separating the effects of the quantity and quality of inflows is not easy. The influence of the new water depends in part on the volume of inflow relative to the existing lake volume. For instance, in 2002, only about 11.5 percent of the full $12.2 \mathrm{~m}$ (40 ft) higher lake volume was from extra inflows. In 2001, about 41 percent of the maximum lake volume was added via pump-back.

Addition of upper Tualatin River water via a Sain Creek tunnel in 2002 produced cooler average lake temperatures and higher dissolved oxygen concentrations. It also produced cooler temperatures and higher dissolved oxygen concentrations in the outflow. The pump-back option, with water from the Tualatin River downstream of the dam, produced cooler average lake temperatures and higher average lake ammonia, chlorophyll $a$, and orthophosphate concentrations. In the outflow, that option produced cooler water temperatures and higher dissolved oxygen, ammonia, chlorophyll $a$, and orthophosphate concentrations. The pumpback option can import a substantial load of phosphorus into the lake, which may cause larger blooms of blue-green algae. The change in chlorophyll $a$ concentrations may be small, but could become important.

\section{Outlet Structures and Operation}

Substantial differences were observed between scenarios using only the original fixed-elevation outlet (scenarios 0,1 , $5,9,10)$ and those that had selective withdrawal capability (scenarios 2-4, 6-8, and 11-15). Use of selective withdrawal to meet a downstream water temperature target led to cooler annual average lake temperatures, warmer overall outflow temperatures, and a shallower thermocline. Scenarios using only the original fixed-elevation outlet produced warmer annual average lake temperatures, cooler summertime outflows, and a thermocline that was deeper overall and progressively deepened through the summer. Selective withdrawal led to less anoxia in the lake, lower annual average lake ammonia concentrations, and shorter blue-green algal blooms.

Simulation of selective withdrawal showed that this technology allowed water released from Hagg Lake to meet downstream temperature criteria, though success varied between the three types of selective withdrawal simulated. The combination of one fixed outlet with one variable-elevation outlet was able to meet the downstream temperature target in 12 of the 14 scenarios where it was used; the 2 which 
did not always meet the criteria had exceedances of less than 1 degree-day. The combination of two fixed outlets had unsatisfactory results in scenarios where significant drawdown occurred, because the ability to blend water from different depths ceased when the upper fixed outlet became dry. Selective withdrawal with only one variable-elevation outlet matched the seasonal trend of the temperature target, but produced large temperature variations in the outflow, exceeding the temperature criteria at times. This occurred because the outlet often was situated in the thermocline, which had a sharp temperature gradient. Seiching of the lake due to wind shear or slight variations in the thermocline structure over a day caused the temperature at the depth of the outlet to change, because the simulation only allowed one adjustment of the outlet elevation per day.

Selective withdrawal scenarios produced higher chlorophyll $a$ concentrations and lower orthophosphate concentrations in the outflow compared to scenarios with the original fixed outlet. The fixed-elevation outlet often drew water below the photic zone, where algal activity occurred.

The existing outlet structure results in the efficient aeration of the released water. If some of this water is routed directly into a pipeline, however, this aeration would not occur. Because some of this water may be used for flow augmentation in the Tualatin River downstream, low dissolved oxygen concentrations could be a concern from September to December (figs. 12, $\underline{13}$ ), unless aeration is engineered into the pipeline.

\section{"Preferred" Options}

After estimating water-supply reliability, cost, regulatory feasibility, and considering input from water users and landowners, three options were designated as "preferred" options by the water management and water supply agencies involved and are undergoing more detailed analysis in an environmental impact statement (EIS). The USGS is involved only to the extent of providing scientific information so that planning decisions are made with a sound technical foundation. The three options are (1) no modification to the dam, (2) the $12.2 \mathrm{~m}(40 \mathrm{ft})$ dam raise with pump-back water,

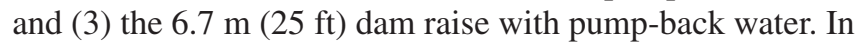
this modeling study, the latter two options were evaluated with selective withdrawal capability. Results for these three options are included in the previous sections of this report, but will be summarized and compared here.

The reservoir with its current configuration starts the year isothermal, cold, and well-oxygenated (Sullivan and Rounds, 2005). A thermocline develops in early summer, and by late
August to October dissolved oxygen becomes depleted in the hypolimnion. Ammonia production and accumulation occurs in the hypolimnion concurrent with the depletion of dissolved oxygen. Algal blooms occur in the lake, and appear to be limited in size by phosphorus availability, water temperature, and other factors.

Compared to this scenario with no modification to the dam, model results for a dam raise with selective withdrawal capability and pump-back water suggest that changes in water quality in Hagg Lake would occur. The modified lake was predicted to have cooler annual average lake water temperatures and a shallower thermocline. Less water with low dissolved oxygen $(<1 \mathrm{mg} / \mathrm{L})$ would be present, and the duration of conditions with low dissolved oxygen in the lake would be shorter. As a result, the concentration of ammonia in the modified lake was predicted to be lower. Orthophosphate and total phosphorus concentrations in the modified lake would be greater than the base case conditions. This is largely due to the source of the pump-back water, the Tualatin River, which has higher orthophosphate concentrations than the natural tributaries to Hagg Lake. The amount of the phosphorus increase depends in part on the volume of water pumped back; for instance, the larger volume of Tualatin River

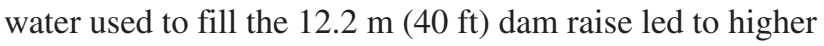
orthophosphate concentrations in the lake compared to the 7.6 $\mathrm{m}(25 \mathrm{ft})$, raise which required less pump-back water (table 5). The concentration of phosphorus in pump-back water varies and also affects lake concentrations; pump-back water had higher phosphorus concentrations in 2002 compared to 2001. Further study and understanding of phosphorus dynamics in the part of the Tualatin River where pump-back would occur could be helpful. The model showed a small increase in lake algal and chlorophyll $a$ concentrations with the pump-back options, as some algal growth is phosphorus limited. However, the altered temperature regime in the modified lake, and other complexities of algal dynamics also could contribute to changes in their concentration or species abundance.

For the outflow, the modified dam was predicted to be able to meet downstream water-temperature criteria in Scoggins Creek if blending from multiple outlets is used; currently the outflow occasionally exceeds those criteria. Outflow dissolved oxygen concentrations were predicted to decrease slightly, with lower predicted minimum concentrations. Ammonia, orthophosphate, and chlorophyll $a$ concentrations in the outflow were predicted to increase slightly. Water diverted directly into a pipeline would have low dissolved oxygen concentrations in the September to November time period, which could affect its use for flow augmentation downstream. 


\section{Other Issues}

Many water-quality issues related to the dam raise are outside the scope of this modeling study. The effect on water quality in the Tualatin River due to the wintertime diversion of water via pump-back or the Sain Creek tunnel was not analyzed. Also, a number of studies (Povari, 1998; Therriault and Schneider, 1998; St. Louis and others, 2004) have shown that mercury concentrations increase in reservoirs and reservoir biota after dam construction. It is thought that organic carbon in newly flooded soils and plants decomposes and increases the microbial methylation of mercury (present from atmospheric deposition or other sources), which then passes mercury into the food chain. Inundation of soils and vegetation also could have an effect on lake nutrient cycling. This possible influx of nutrients might influence algal species composition and concentration in the lake. Other issues not addressed in this study include the effect of a raise in crest gate elevation on total dissolved gas levels below the dam, and the effect of climatic or meteorologic variation on lake water quality.

\section{Acknowledgments}

This study was conducted with cooperative funding provided by USGS, Clean Water Services, the Tualatin Valley Water District, and the Cities of Tigard, Hillsboro, Beaverton, Sherwood, Forest Grove, Tualatin, North Plains, Cornelius, and Banks. Tom VanderPlaat (CWS) and Ryan Murdock and Lisa Obermeyer (Montgomery Watson Harza) provided constraints for the pump-back option. We appreciate the helpfulness of Wally Otto (Tualatin Valley Irrigation District), who operates Scoggins Dam, for sharing some of the details of dam operation and helping us to understand the plumbing in Scoggins Dam. We also thank the Bureau of Reclamation, the Joint Water Commission, Clean Water Services, the Oregon Water Resources Department, and all others who contributed data or other details to better frame these model scenarios. Finally we thank Laurel Saito (University of Nevada, Reno), Paul Woods (USGS), Chris Berger (Portland State University), Tom VanderPlaat (CWS), Bryan Horsburgh (Bureau of Reclamation), and Lisa Obermeyer and Ryan Murdock (Montgomery Watson Harza) for their helpful comments from a review of this report.

\section{Supplemental Material}

A web site has been created to distribute supplemental material from this project. Visitors to http://or.water.usgs. gov/tualatin/hagg lake/scenarios/ will be able to:

- Learn more about this project,

- Download this report,

- Download or view visualizations of model output, and

- Download the model code used in the scenarios.

The web site includes additional graphics with results from all of the model scenarios.

\section{References Cited}

Bales, J.D., Sarver, K.M., and Giorgino, M.J., 2001, Mountain Island Lake, North Carolina: Analysis of ambient conditions and simulation of hydrodynamics, constituent transport, and water-quality characteristics, 1996-97: U.S. Geological Survey Water-Resources Investigations Report 01-4138, $85 \mathrm{p}$.

Bartholow, J., Hanna, R.B., Saito, L., Lieberman, D., and Horn, M., 2001, Simulated limnological effects of the Shasta Lake temperature control device: Environmental Management, v. 27, no. 4, p. 609-626.

Casamitjana, X., Serra, T., Colomer, J., Baserba, C. and Perez-Losada, J., 2003, Effects of the water withdrawal in the stratification patterns of a reservoir: Hydrobiologia, v. 504, p. 21-28.

Cherry, D.S., Dickinson, K.L., Cairns, Jr., J. and Stauffer, J.R., 1977, Preferred, avoided, and lethal temperatures of fish during rising temperature conditions: Journal of the Fisheries Research Board of Canada, v. 34, p. 239-246.

Cole, T.M. and Wells, S.A., 2002, CE-QUAL-W2: A twodimensional, laterally averaged, hydrodynamics and water quality model, version 3.1: U.S. Army Corps of Engineers, Instruction Report EL-02-1 [variously paged].

Ferrari, R.L., 2001, Henry Hagg Lake 2001 Survey: Bureau of Reclamation, $17 \mathrm{p}$.

Ferguson, R.G., 1958, The preferred temperature of fish and their midsummer distribution in temperate lakes and streams: Journal of the Fisheries Research Board of Canada, v. 15 , p. 607-624. 
Green, W.R., 2001, Analysis of ambient conditions and simulation of hydrodynamics, constituent transport, and water-quality characteristics in Lake Maumelle, Arkansas, 1991-92: U.S. Geological Survey Water-Resources Investigations Report 01-4045, $60 \mathrm{p}$.

Hanna, R.B., Saito, L., Bartholow, J.M., and Sandelin, J., 1999, Results of simulated temperature control device operations on in-reservoir and discharge water temperatures using CE-QUAL-W2: Journal of Lake and Reservoir Management, v. 15(2), p. 87-102.

Horne, A.J., and Goldman, C.R., 1994, Limnology, 2nd ed.: New York, McGraw-Hill, 576 p.

Montgomery Watson Harza, 2004, Tualatin Basin water supply feasibility study_-Final report: available upon request from Clean Water Services, Hillsboro, OR or online at http://www.cleanwaterservices.org/content/documents/ Water Supply Study/Water Supply Study Final Report.pdf, accessed January 2006.

Oregon Department of Environmental Quality, 2003, Oregon Administrative Rules - Temperature criteria, OAR 340-0410028: http://arcweb.sos.state.or.us/rules/OARs 300/OAR 340/340 041.html, accessed May 26, 2005.

Povari, P., 1998, Development of fish mercury concentrations in Finnish reservoirs from 1979 to 1994: Science of the Total Environment, v. 213, p. 279-290.

Rounds, S.A. and Wood, T.M., 2001, Modeling water quality in the Tualatin River, Oregon, 1991-1997: U.S. Geological Survey Water-Resources Investigations Report 01-4041, $53 \mathrm{p}$.
St. Louis, V.L., Rudd, J.W.M., Kelly, C.A., Bodaly, R.A., Paterson, M.J., Beaty, K.G., Hesslein, R.H., Heyes, A., and Majewski, A.R., 2004, The rise and fall of mercury methylation in an experimental reservoir: Environmental Science and Technology, v. 38, p. 1348-1358.

Sullivan, A.B. and Rounds, S.A., 2004, Modeling streamflow and water temperature in the North Santiam and Santiam Rivers, Oregon, 2001-02: U.S. Geological Survey Scientific Investigations Report 2004-5001, 35 p.

Sullivan, A.B. and Rounds, S.A., 2005, Modeling hydrodynamics, temperature, and water quality in Henry Hagg Lake, Oregon, 2000-2003: U.S. Geological Survey Scientific Investigations Report 2004-5261, 38 p.

Therriault, T.W. and Schneider, D.C., 1998, Predicting change in fish mercury concentrations following reservoir impoundment, Environmental Pollution, v. 101, 33-42.

Tualatin River Flow Management Technical Committee, 2001, 2001 Annual report: available upon request from Clean Water Services, or online at http://www.co.washington. or.us/deptmts/wtr mstr/downloads/FlowReport.2001.pdf.

Tualatin River Flow Management Technical Committee, 2002, 2002 Annual report: available upon request from Clean Water Services, or online at http://www.co.washington. or.us/deptmts/wtr mstr/downloads/FlowRpt2002.pdf.

World Health Organization, 2003, Ammonia in Drinking water. Background document for development of WHO Guidelines for Drinking-Water Quality. WHO/SDE/ WSH/03.04/ 01, accessed May 4, 2005, at http://www.who. int/water sanitation health/dwq/en/ammonia.pdf. 
32 Modeling Water Quality Effects of Structural and Operational Changes to Scoggins Dam and Henry Hagg Lake, Oregon

This page intentionally left blank 


\section{Appendix A. A New "Withdrawal Blending" Capability for CE-QUAL-W2}

Modifications were made to CE-QUAL-W2 to enable it to blend withdrawals from more than one lake outlet, and set the depth of any adjustable-depth outlets, in order to meet a user-specified time series of target temperatures for water released from a reservoir. In this way, the model can be used to (1) assess whether certain downstream temperature targets can be met under various structural and operational scenarios, (2) assess the effects of using different types of outlets, either singly or in combination, and (3) assess the effects of specifying different temperature targets, among other things. Some of these objectives, such as using multiple fixed outlets to meet a downstream temperature target, could have been accomplished with the model previously, but only by running the model multiple times and iterating on the flow rates from each outlet. The changes added by the USGS modeling team allow these tasks to be accomplished in a single model run, because the necessary operational changes are done automatically.

Several additions were made to the model in order to implement this new ability to blend withdrawals from multiple outlets. The most important of these changes are listed below.

1. Each withdrawal is now given a user-specified "bottom elevation limit," corresponding to the lowest elevation from which that outlet can withdraw water. This simulates any physical limits of an outlet structure. If the water surface declines below this level, the outlet is dry and no water can be withdrawn from that outlet.

2. Each withdrawal is now classified by the model user as either a fixed-elevation outlet, a "floating" outlet, or a sliding-gate outlet (fig. A1). Fixedelevation outlets have an unchanging centerline outlet elevation. Floating outlets are hydraulic structures that may stretch the limits of modern engineering, but are nevertheless useful to imagine in a modeling exercise; in the model, their centerline outlet elevation is always set to 1.5 meters below the water surface, unless the water surface declines below the outlet's bottom elevation limit. Sliding-gate outlets have a variable outlet elevation, adjusted by the model, that ranges between the outlet's bottom elevation limit and the water surface.

3. Each withdrawal is assigned to a "withdrawal group" for modeling purposes. A total withdrawal flow rate is assigned by the user to each group rather than to each individual withdrawal. Flows from the withdrawals in each group are adjusted by the model to match the total withdrawal flow rate for the group. If a group is assigned more than one withdrawal, or if one of the withdrawals is a sliding-gate outlet, then it is assumed that the user wishes to match a downstream temperature target. In that case, the group is assigned a user-specified time series of target water temperatures. The model then will attempt to blend water from the various outlets in that group and set the elevation of any variable-elevation outlets in that group to meet the target water temperature.

4. To simulate a situation in which dam operators must make decisions about the blending of flows from different outlets, the model only adjusts the blending of flows a user-specified number of times per day. For example, in a model simulation in which water from two fixed-elevation outlets is blended to meet a specified temperature target, the total amount of water withdrawn from the two outlets is set by the user in the normal manner. The model determines how much of that total to withdraw from each of the two outlets, in an attempt to match the target temperature. The user, however, specifies how many times per day and at what time of day the model can make its blending adjustment. The model was set up this way to simulate the fact that these adjustments may be done manually and that practical reasons may preclude frequent adjustments. For the same reasons, the model also allows the user to give the dam operator the weekend off, in which case no blending adjustments are made on Saturday or Sunday. (A day-of-week function was added for this calculation.)

5. No more than two outlets are used for blending at any one time. If more than two outlets are assigned to the same withdrawal group, and more than two of those outlets are below the water surface, then the model applies a set of rules to determine which two outlets to use. All other outlets in the group are turned off (zero flow). When more than two outlets are available, multiple solutions to the blending problem can be calculated; by using only two outlets, the solution becomes straightforward and is described below. The following rules are used to determine which outlets to use and which ones to close:

a. The highest and lowest outlets that are "wet" generally are used. The rest of the rules are an attempt to enforce this rule and maintain a maximum amount of flexibility to access water through as much of the water column as possible. 


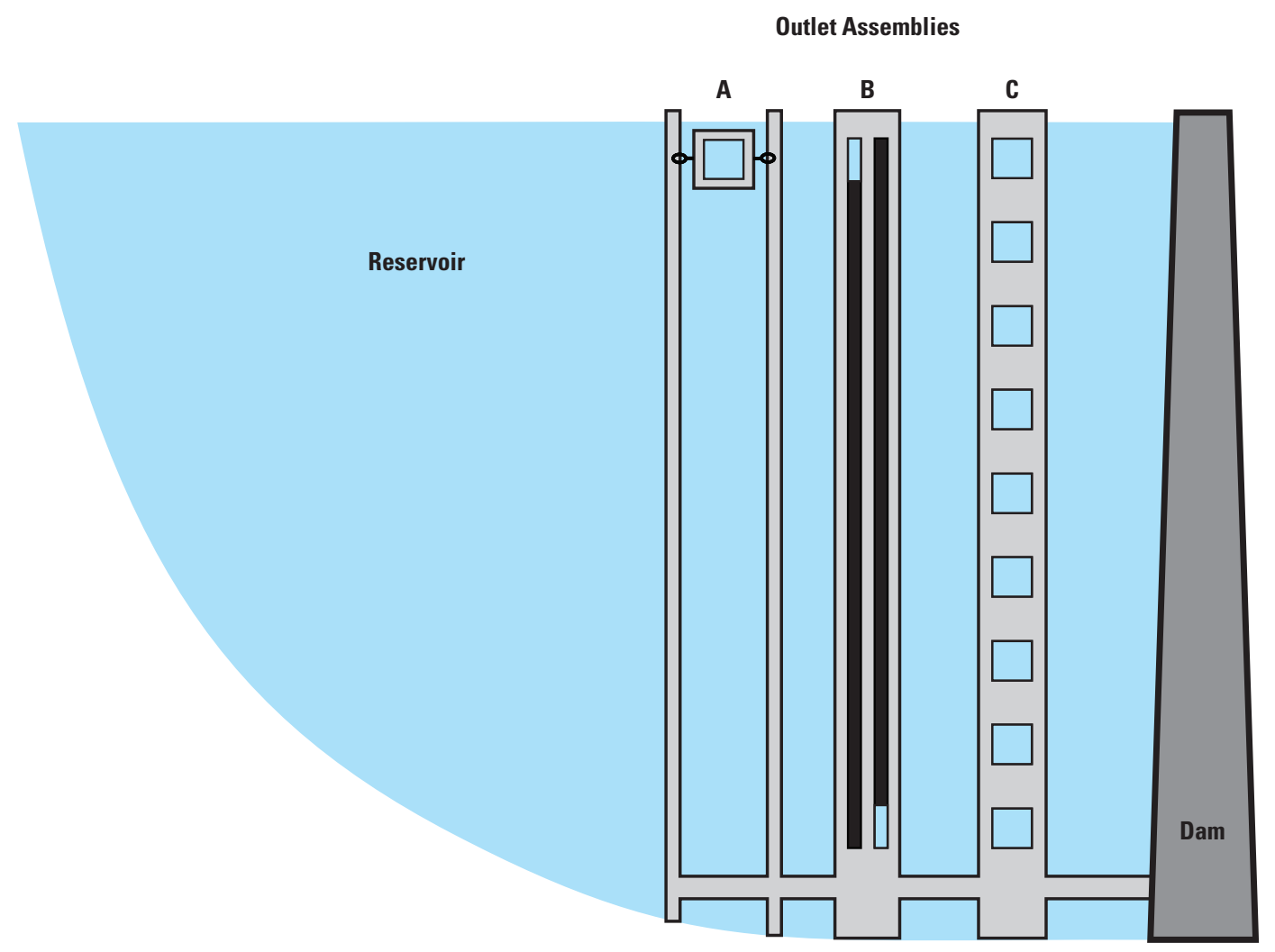

Figure A1. Several assemblies of potential CE-OUAL-W2 outlet types.

Assembly A contains one "floating" outlet. Assembly B contains two adjustable-elevation or sliding-gate outlets whose openings happen to be positioned near the top and bottom of the reservoir. Assembly $C$ contains nine fixed-elevation outlets. These are the three types of outlets (floating, sliding-gate, and fixed-elevation) recognized by the new blending subroutine in CE-QUAL-W2.

b. Sliding gates are preferred over floating outlets because they are more flexible in accessing water with different temperatures.

c. Fixed outlets are preferred over floating outlets when a sliding-gate outlet is present.

d. A floating or sliding-gate outlet is preferred over the highest of two fixed outlets.

e. Only one floating outlet is ever necessary. Given any other type of outlet, only one floater will ever be considered for use.

f. The lowest fixed outlet is preferred when the other outlet is either a floater or a slider.

g. A sliding-gate outlet is preferred over another sliding-gate outlet if its bottom elevation limit is lower. h. When two sliding-gate outlets are present, a fixed outlet is preferred over the shorter slider only if the fixed outlet is lower than the bottom elevation limits of both sliders.

6. The depth of the opening of a sliding-gate outlet is set by the model in response to a need to access water of a certain temperature. If a sliding gate is used by itself, the model will set the elevation of its opening at the point in the water column that best matches the target temperature. If a sliding-gate outlet is one of a pair of outlets being blended to meet a target temperature, the sliding gate is set either near the water surface (1.5 meters depth), or deep in the lake, 1 meter above its bottom elevation limit, depending on whether the target temperature is warmer or colder than the water available to the other outlet. 
When flows from two outlets are blended to meet a target temperature, determining the flow from each outlet is a straightforward calculation. The total release rate from the withdrawal group is known because it was set by the user in the model's withdrawal flow file. The target temperature also is known. If more than two outlets are available within a withdrawal group, the model's rules, described above in item 5 , are used to select the two active outlets. The depth of each outlet is known, and therefore the simulated water temperature in the lake at the depth of each outlet also is known. The flows in each outlet, then, are calculated using the following equations. Conservation of energy requires that:

$$
Q_{\text {target }} T_{\text {target }}=Q_{1} T_{1}+Q_{2} T_{2},
$$

where

$Q_{\text {target }}$ is the total release rate,

$T_{\text {target }}$ is the target temperature,

$Q_{1}$ is the flow in the first outlet,

$T_{1}$ is the temperature associated with the first outlet,

$Q_{2}$ is the flow in the second outlet, and

$T_{2}$ is the temperature associated with the second outlet.

Conservation of mass requires that:

$$
Q_{\text {target }}=Q_{1}+Q_{2} \text {. }
$$

Determining the value of $Q_{1}$, therefore, is a simple matter of substituting $Q_{2}$ with $\left(Q_{\text {target }}-Q_{1}\right)$ and solving for $Q_{1}$, which leaves:

$$
Q_{1}=Q_{\text {target }} \frac{T_{\text {target }}-T_{2}}{T_{1}-T_{2}}
$$

Once $Q_{1}$ is found, the value of $Q_{2}$ is determined through application of equation A2. Note that equation A3 applies only when the target temperature is between the temperatures at the two selected outlets; this is why the outlet selection rules outlined above were crafted to select the two outlets that can draw water from as high and as low in the water column as possible, thus maximizing the available temperature difference $T_{1}-T_{2}$.

If the target temperature is greater or less than both of the outlet temperatures, the model assigns all flow to the outlet having the temperature closest to the target temperature. If the two outlet temperatures are identical, then flow is split equally between the two outlets only if those temperatures also equal the target temperature; otherwise, a higher target temperature results in all flow being assigned to the higher outlet while a lower target temperature results in all flow being assigned to the lower outlet.

For more details on how the model implements this blending strategy, the ultimate source of information is the model's source code, which is available online at the project website: http://or.water.usgs.gov/tualatin/hagg lake/ scenarios/. Note that the model code also implements a set of "avoidance" algorithms in which "avoidance rules" may be set by the user and consulted by the model when making decisions concerning which outlets to choose for blending. For example, the user could tell the model to avoid withdrawing any water where the dissolved oxygen is less than a certain concentration, and/or where the ammonia exceeds some concentration. No avoidance rules were used in the Hagg Lake model runs, though they may be used in future scenarios. At this point, the avoidance algorithms are fairly simple and could be improved in the future.

In addition to the algorithms that take care of the blending details, new output options were added to the model that aid in documenting how the blending was done. Such output includes the actual flow rate from each of the withdrawals involved in blending, their elevation, and the layers in the model from which the water ultimately was withdrawn. 
This page intentionally left blank 
Manuscript approved for publication, February 28, 2006

Prepared by the U.S. Geological Survey Publishing Network,

Publishing Service Center, Tacoma, Washington

Bill Gibbs

Jackie Olson

Sharon Wahlstrom

For more information concerning the research in this report, contact the Director, Oregon Water Science Center

U.S. Geological Survey

10615 SE Cherry Blossom Drive

Portland, Oregon 97216

http://or.water.usgs.gov/ 


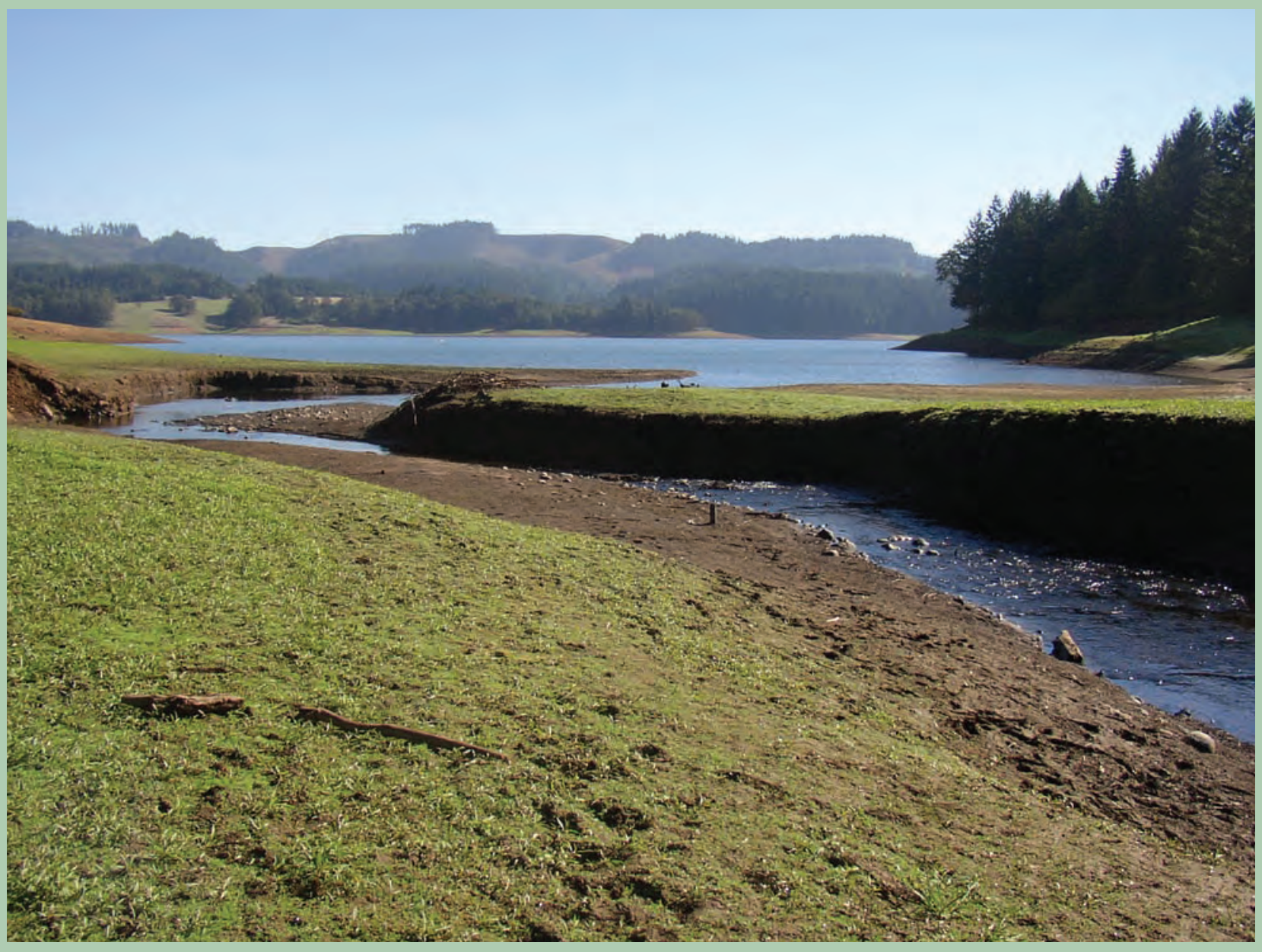

